\title{
21. BENTHONIC FORAMINIFERAL BIOSTRATIGRAPHY IN THE CENTRAL NORTH PACIFIC, LEG 17, DEEP SEA DRILLING PROJECT ${ }^{1}$
}

\author{
Robert G. Douglas, Department of Geology, Case Western Reserve University, Cleveland, Ohio
}

\section{GENERAL REMARKS}

Benthonic foraminifera are the most common and abundant remains of benthic life preserved in deep-sea sediments. Other invertebrate groups have representatives which live in the deep ocean, and some groups are both diverse and abundant. However, only foraminifera, and to a lesser extent ostracods, produce shells which are readily preservable and fairly numerous. Benthonic foraminifera have a fossil record in the deep sea that extends at least back to the Jurassic (Luterbacher, 1971) and are the main source of information on the benthic biostratigraphy of ancient deep-sea deposits.

Foraminiferal assemblages were examined from two Leg 17 sites, Sites 167 and 171. At these sites much of the Quaternary, Tertiary, and Cretaceous are represented. The early Eocene and Paleocene are missing except for an incomplete section of Paleocene at Site 167. Nearly complete sections of Upper Cretaceous were cored at both sites. Benthonic foraminifera are present in all the cores from Site 171 and in all of the cores down to the Campanian (Core 57) at Site 167. Below this level the lithology is hard limestone, and foraminifera are absent except for rare casts of nodosariids.

Prior to the Deep Sea Drilling Project, information about deep-sea benthonic foraminifera was primarily limited to Quaternary assemblages because of the sparsity of older core material. The main sources of information on Tertiary and Cretaceous faunas was from deep-sea deposits which have been uplifted and now crop out on islands or continental margins, for example, the studies of Beckmann (1953) on the Oceanic Formation of Barbados; Cushman and Stainforth (1945) and Cushman and Renz (1946, 1947, 1948) on the Tertiary formations of Trinidad; Nuttall (1932) and Cushman (1926) on the Paleogene of Mexico; and Hedberg (1937). More recently Tertiary and Cretaceous benthic assemblages have been described from boreholes in deep-sea settings (Parker, 1964; Peterson, etal., 1970; Luterbacher, 1972; Douglas and Moullade, 1972; Maync, 1973). These studies indicate that the majority of the species present in deep-sea cores are the same as those described from the continental margins. Many of these bathyal species have wide geographic distributions, particularly in the Cretaceous and Paleogene, and limited stratigraphic ranges. For these reasons, they offer an excellent basis for biostratigraphic correlation, especially to supplement planktonic biostratigraphy.

\footnotetext{
${ }^{1}$ Contribution No. 98, Department of Geology, Case Western Reserve University.
}

\section{SAMPLING}

Benthonic foraminifera are generally not abundant in deep-sea sediments. In well-preserved Recent sediments they comprise $0.1 \%$ to $0.5 \%$ of the foraminiferal assemblages (Scott, 1935; 1966; Parker and Berger, 1971; Thiede, 1971). However, in carbonate sediments which have suffered dissolution and in winnowed or redeposited sediments, the percentage of benthonic may be much greater. Most benthonic species seem to be more resistant to dissolution than planktonic species, and below the lysocline benthonic foraminifera may exceed $10 \%$ of the total foraminiferal assemblage (Parker and Berger, 1971). Benthonic species are generally thicker walled and heavier than planktonic ones and are preferentially enriched in sediment by winnowing or redeposition.

Because of the low abundance of benthonic foraminifera in deep-sea sediments, sample size is particularly important. The normal sample size taken from DSDP cores is 8 to 10 cc of material. Such samples yield from a few tens upwards to a couple hundred specimens, representing a few tens of species (Figure 1). Core-catcher samples of 20 to $50 \mathrm{cc}$ of core material yield much richer assemblages consisting of 300 to 800 individuals and upwards of 100 species. A plot of species diversity against species frequency suggests that a sample containing 300 individuals or more is needed in order to be considered a representative sample. The total number of species in deep-sea samples seems to be large but the upper limits for deep-sea diversity are unknown. In the present study only material greater than $100 \mu$ in diameter was examined, and no samples greater than $60 \mathrm{cc}$ of core material were available. Within these limitations, wellpreserved samples usually contained 80 to 100 species and established a minimum value. Samples yielding fewer than about 300 specimens underrepresent the rarer species.

Fossil populations of benthonic foraminifera exhibit strong dominance; that is, a few species account for the majority of individuals in any sample. Commonly, two or three species account for $30 \%$ to $50 \%$ of the populations (Figure 2). Most of the remaining species are represented by fewer than five individuals each. One result of such a population distribution is that with small sample size only the few dominant (abundant) species are consistently presented. The rarer species have sporadic occurrences from sample to sample, and their abundance varies greatly.

The interplay of the low abundance and the species-freqeuncy distributions of benthonic foraminifera in deep-sea sediments have an important bearing on the use of these foraminifera for biostratigraphic and paleoecologic purposes. For the greatest utility, zonation should be based wherever possible on the dominant species. Although they are only a small fraction of the total assemblage, it is these species that have the greatest chances of occurring in the small sample size normally available from cores $(10 \mathrm{cc})$ and 


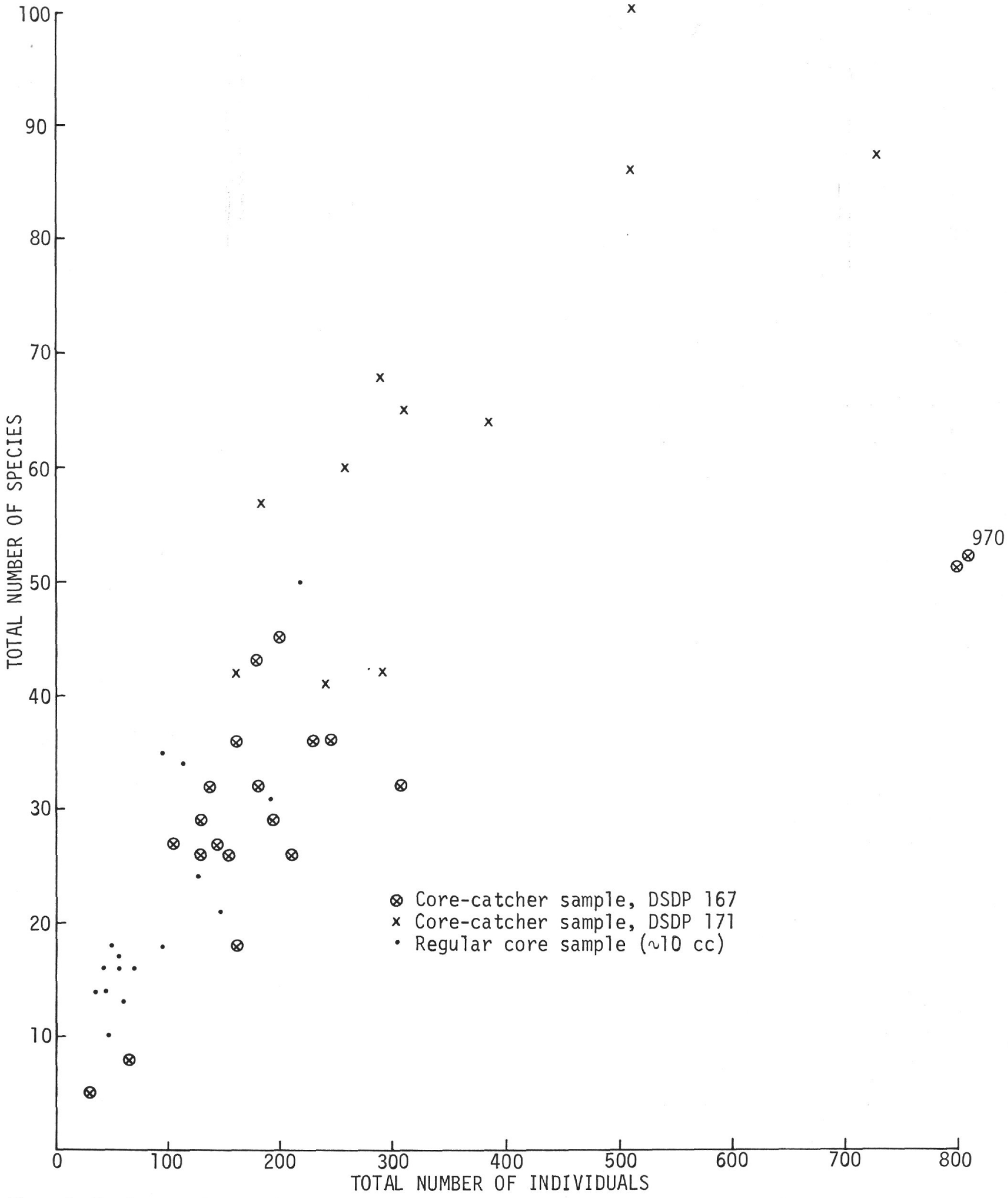

Figure 1. Total species diversity-frequency plot of benthonic foraminifera recovered in samples from Sites 167 and 171 . 

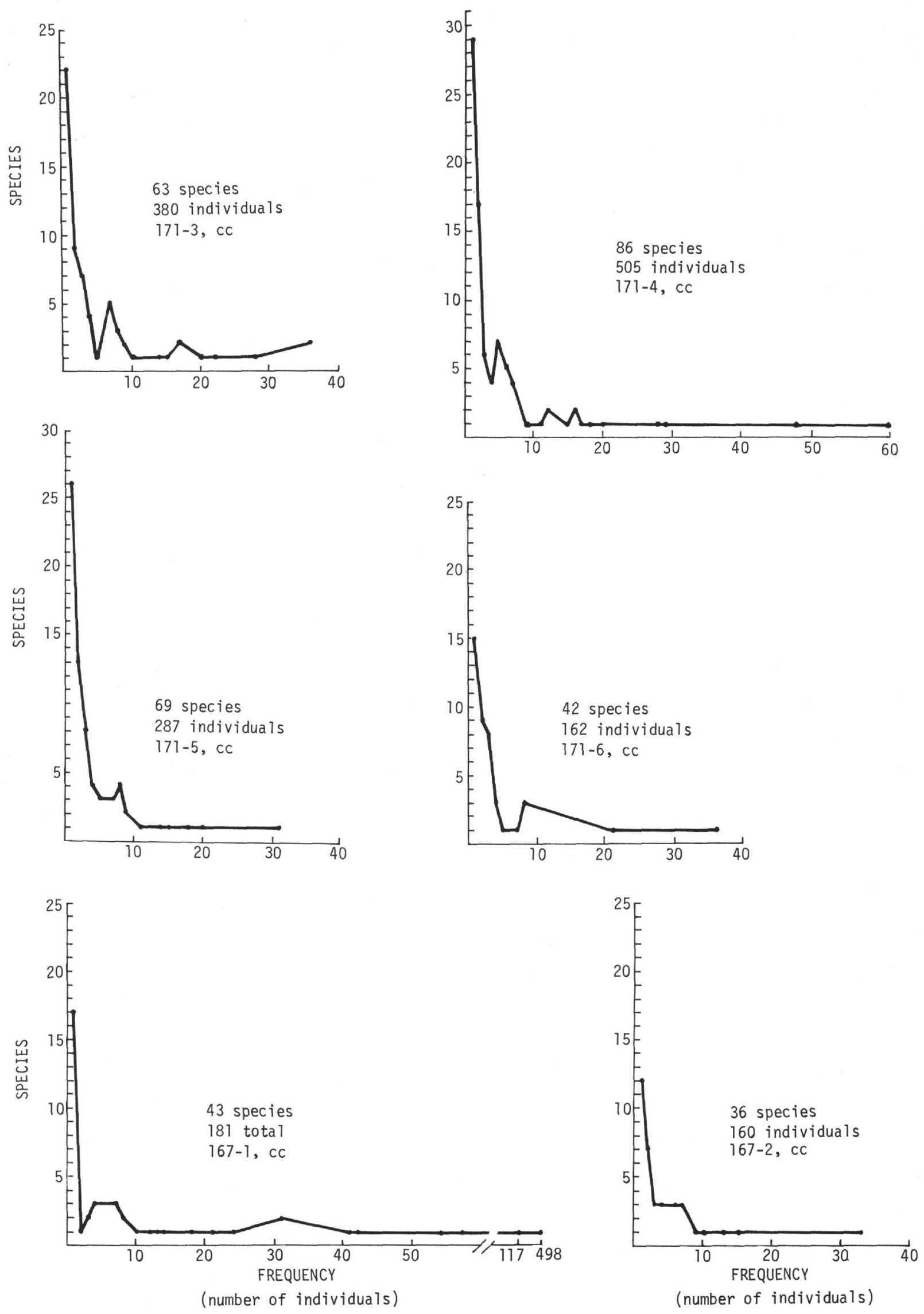

Figure 2. Species-frequency distributions for select benthonic foraminiferal assemblages from Sites 167 and 171 . 
of occurring from sample to sample to sample so that reliable stratigraphic ranges can be established.

\section{PRESERVATION}

On the average, benthonic foraminifera are more preservable than are planktonic foraminifera. They are more resistant to dissolution and, in some cases, mechanical breakage than pelagic species. The preferential loss of planktonic foraminifera relative to benthonic foraminifera is well illustrated by the down-hole changes in foraminifera at Site 167 (Figure 3) (see Chapter 13). The changes which occur with increased depth of burial, lithification (ooze, chalk, limestone), and dissolution incluce the following:

1. A deterioration in surface luster and in the transparency of rotalliid taxa. This seems to be the initial sign of dissolution. Shells from the Quaternary (Cores 1 and 2) have smooth surfaces and shiny lusters. Miliolids (Pyrgo and Quinqueloculina) have bright procelaneous surfaces. However, by late Miocene (Cores 4 and 5) these lusters have been lost or are considerably duller in appearance. Miliolids have a chalky luster, and most shells are broken or with holes. Some hyaline shells have acquired a cloudy appearance.

2. A preferential removal of miliolids with respect to the rotaliid taxa. Pyrgo is a common genus in Core 1 and accounts for over $10 \%$ of the total foraminiferal faunas (Table 1). Five cores lower in the middle Miocene, Pyrgo accounts for about $1 \%$ of the fauna and is represented mostly by broken species which are filled with holes. No miliolids were found below Core 8 which corresponds to the beginning of the transition from ooze to chalk.

3. A rapid down-hole increase in the percentage of broken tests (Figure 3). This occurs in the upper four cores: thereafter, the percentage ranges between $20 \%$ and $50 \%$ down to around Core 27 (upper Eocene). Below this level the percentage of broken tests decreases as the total number of benthonic foraminifera decreases. In the firm to hard chalks and limestones of the early Tertiary and Cretaceous, foraminiferal loss increases noticeably. Related to the number of broken tests is the number of tests with holes. Both features appear to be largely the result of dissolution and predation, both of which weaken tests.

4. Calcite overgrowth and chamber infilling. Beginning in the Oligocene chalks, calcite overgrowth was noted on the inner chamber wall of some species. This involves the development of small crystals of calcite and the cementation of coccoliths in the pores and in the surface of the chamber wall. Chamber infillings of calcite occur in the lower part of the chalk sequence but were more common in the limestone and chalks of the Cretaceous. For reasons that are unknown, chamber infillings were primarily restricted to thick-walled, gyroidinoid types and nodosariids. Calcite overgrowth occurred on all rotaliid types; no miliolid taxa were observed with either calcite overgrowth or chamber infillings. The percentage of species with calcite overgrowth and infillings increased rapidly in the Cretaceous cores below Core 50 (upper Campanian), and all specimens were so "recrystallized" below Core 55 (lower Campanian).
On the whole, and as one might predict, the species with the thickest walls and lowest porosity appear to be the most preservable. Thin-walled, rectilinear types and species with a large number of pores seem to be the least preservable. Miliolid species are less preservable than are rotaliid species. Agglutinated species seem to hold an intermediate position between porcelaneous calcareous taxa and hyaline calcareous taxa. Agglutinated taxa with smooth textures generally showed a high degree of selectivity in building materials. In at least one case, Textularia leuzingeri Cushman and Renz (see Plate 2, Figures 7-9), a single nannofossil species was the predominant building material. These fossils seem to survive better than species that used less selective materials with a wider range in size of individual grains. Among the agglutinated taxa studied, Vulvulina and Karreriella were the most resistant genera, and Bolivinopsis and hyperammina-like genera were the most fragile genera.

An important feature in determining the ultimate preservation of individual species is the degree and type of predation that the shell suffers. Many tests, in some samples nearly the majority of the tests, were bored, tunneled, or corroded as the result of predation action (see Plate 1). Borings very similar to those described and illustrated by Sliter (1971) were the most common type of shell predation. Sliter suggested that nematodes were probably responsible for the holes rather than predaceous gastropods. Judging from the morphology of the holes found in deep-sea sediments, i.e., oval shaped, parallel sided, and beveled at one side of the opening, nematodes seem the most likely predator. At Sites 167 and 171, certain species or genera seem more susceptible to boring than other taxa. For example, the wide keel surrounding Laticarinina is always penetrated by small anastomosing tubes or tunnels, while each chamber is penetrated by a single, oval-shaped hole. Bolivinid types (Bolivina, Coryphostoma, etc.) seem to have been favorite targets for predators. The only calcareous taxa which seems to be consistently without holes was Cibicidoides. However, it is possible that the large pores on the spiral face made it unnecessary to drill the shell, or the holes are not apparent. It was also noted that Vulvulina, Bolivinopsis, and most Karreriella lack predaceous holes. However, Textularia and Dorothia seem to be bored as often as most calcareous species. No quantitative count was made between the percentage of predated shells on Magellan Rise versus Horizon Guyot, but the impression is that more tests had been preyed up at Magellan Rise. This may reflect the deeper water and closer proximity to the high equatorial productivity zone of this site. Sliter (1971) noted a correlation between the organic content of the sediments and percentage of predated shells in Recent environments.

The number and nature of the holes or tunnels, etc. tend to reduce the resistance of the shell to mechanical breakage and probably increases dissolution (by increasing surface area). Species which seem to be preferentially bored in the well-preserved oozes were absent or rare in the more compact chalks. Below the Eocene (Core 27), in the firm chalks and limestones, shells with borings, etc. were noticeably rare or absent. It is believed that they had been preferentially destroyed by diagenetic processes. 


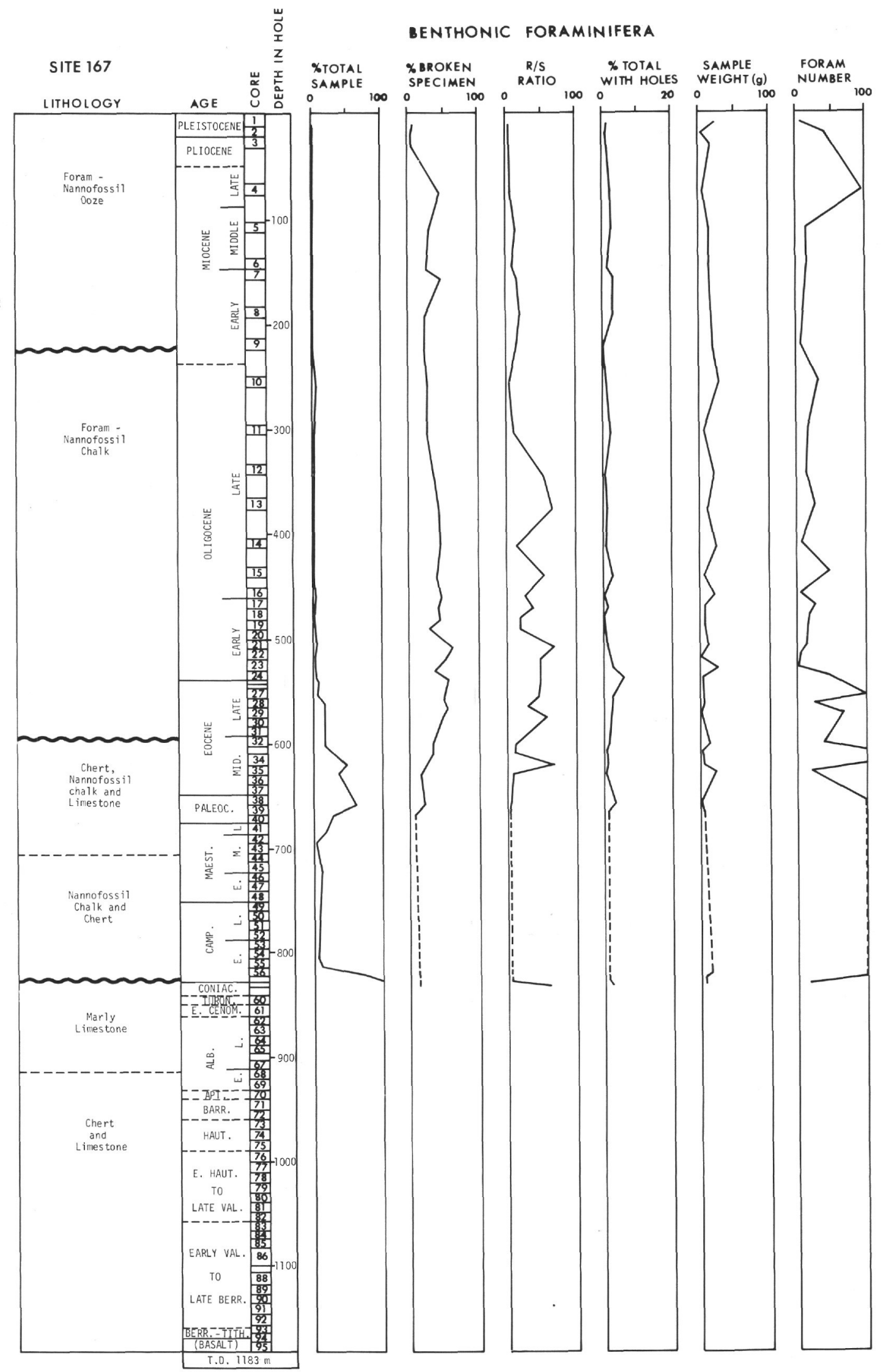

Figure 3. Relative abundance, foraminiferal number, and relative preservation of assemblages from Site $167 . R / S$ ratio is the ratio of rectilinear species to trochospiral species. Sample weight is based on the washed residue greater than $74 \mu$ in size. Foraminiferal number is defined as the number of benthonic specimen per gram of sample (washed residue). 
TABLE 1

Stratigraphic Distribution and Relative Abundance of Benthonic Species at Site 167

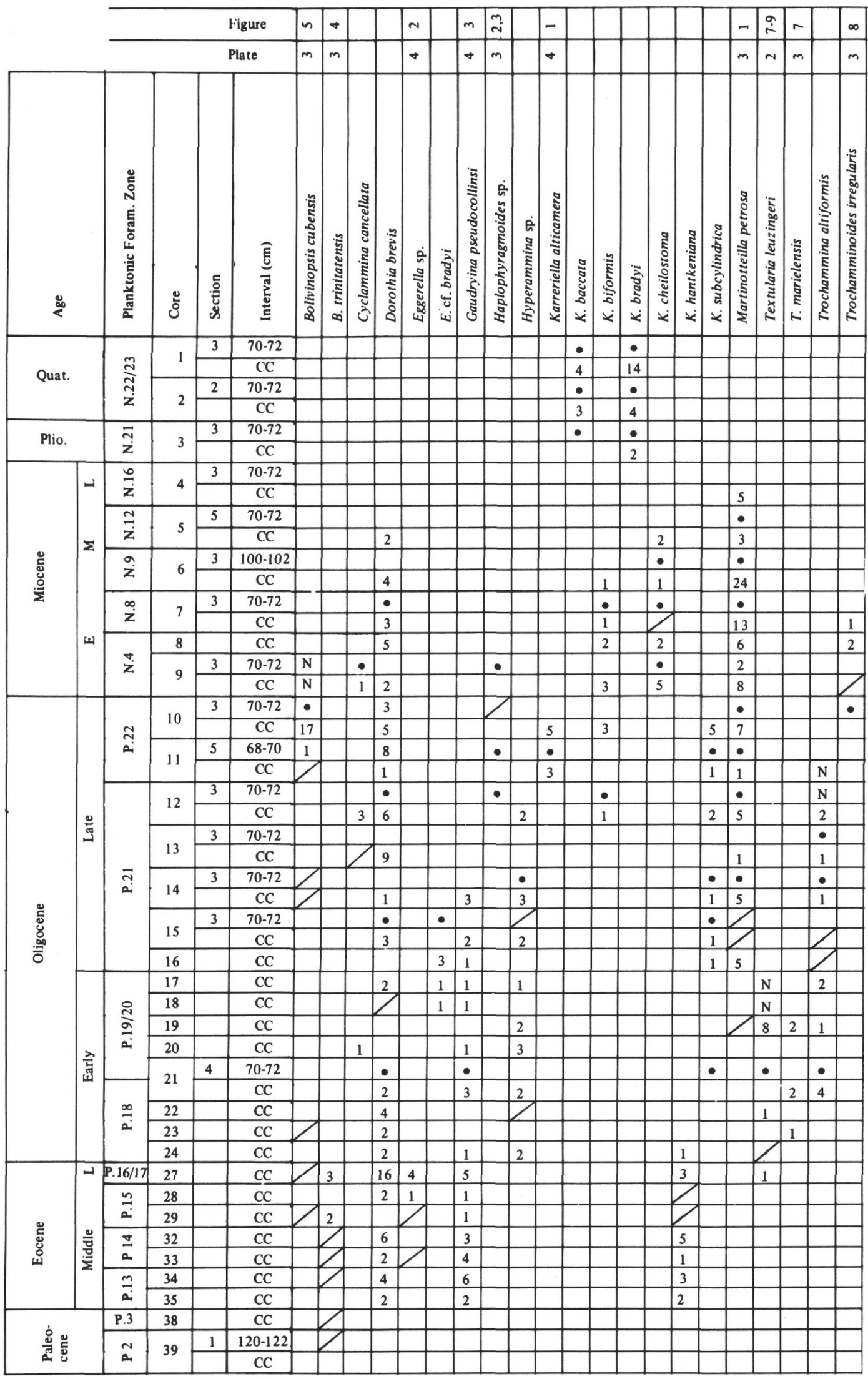

Legend:

- = Species present no count made; 12,34 etc, = number of individuals counted; / = broken individuals only;

$\mathrm{N}=$ not present, species specifically searched for but not found. 
TABLE 1 - Continued

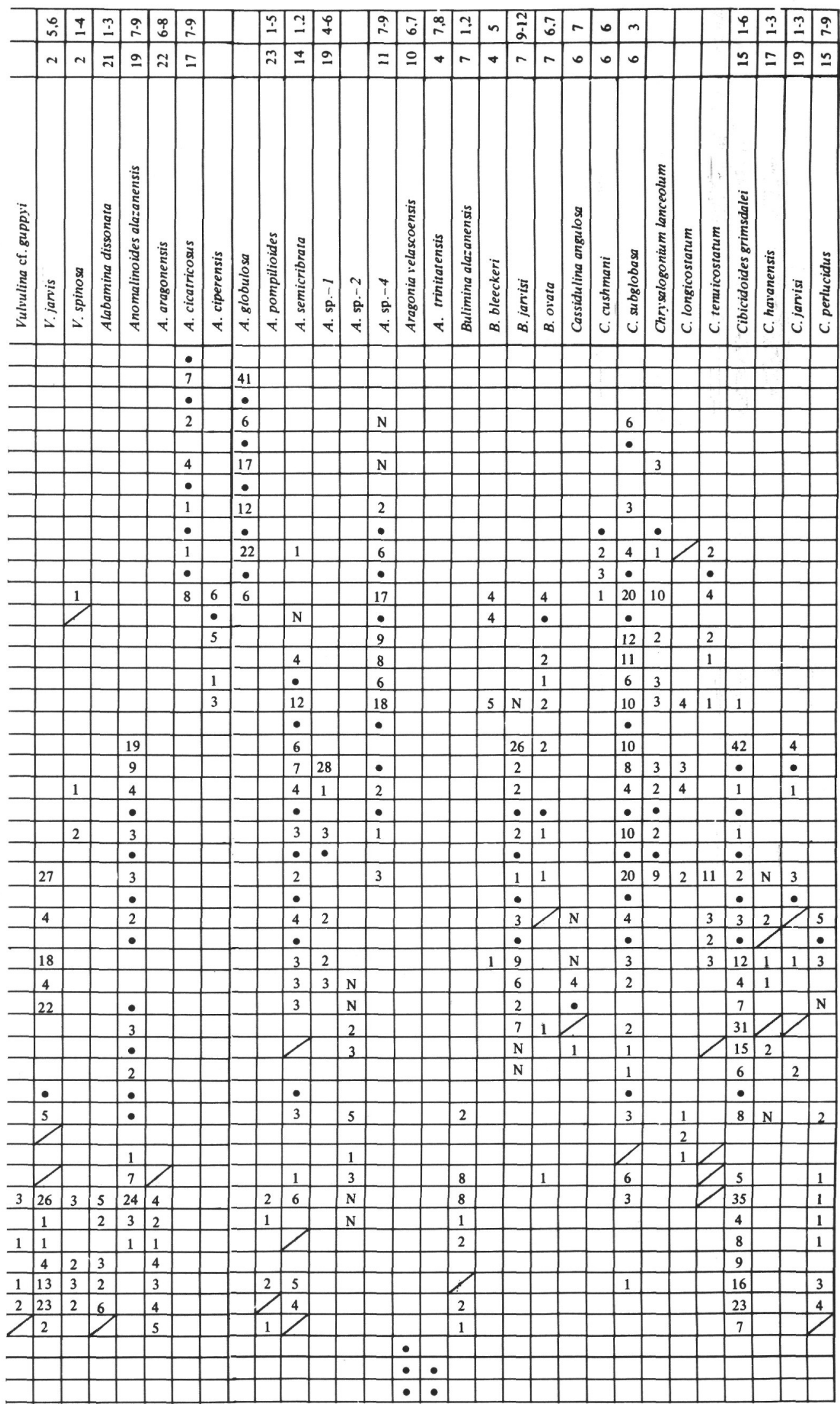


TABLE 1 - Continued

\begin{tabular}{|c|c|c|c|c|c|c|c|c|c|c|c|c|c|c|c|c|c|c|c|c|c|c|c|c|c|}
\hline & & \multicolumn{4}{|r|}{ Figure } & & & \begin{tabular}{l|l}
9 \\
$i$
\end{tabular} & \multicolumn{2}{|r|}{$\cong$} & \begin{tabular}{l|l} 
& I \\
\end{tabular} & \multicolumn{2}{|c|}{\begin{tabular}{l|l|} 
& $\begin{array}{l}n \\
+ \\
\end{array}$ \\
\end{tabular}} & \begin{tabular}{l|l}
9 & $y$ \\
\end{tabular} & \multicolumn{2}{|c|}{9} & \multicolumn{3}{|c|}{\begin{tabular}{|l|l|l|}
9 & 9 & 2 \\
\end{tabular}} & $\infty$ & & $\cong$ & ज. & $m$ \\
\hline & & & & & Plate & $\approx$ & v & $\stackrel{\infty}{-}$ & $\stackrel{\infty}{-}$ & & 이 & $n$ & 0 & 0 & $\stackrel{\infty}{-}$ & $\approx$ & $\approx$ & $\approx$ & & & $\cong$ & & \begin{tabular}{l|l}
$a$ & 0
\end{tabular} & $a$ & $a$ \\
\hline & & 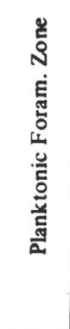 & oั & 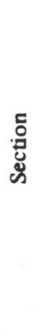 & 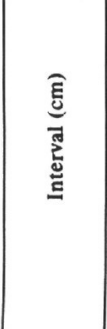 & 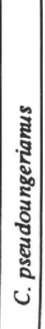 & 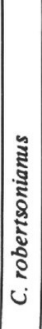 & 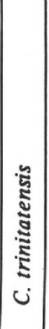 & 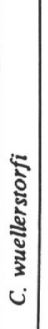 & 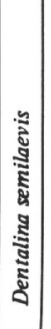 & 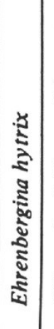 & 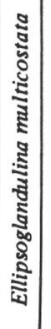 & 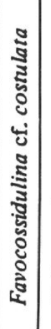 & 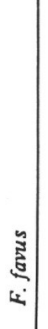 & 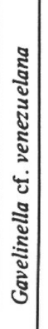 & 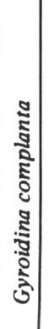 & 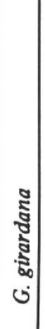 & 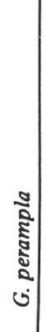 & 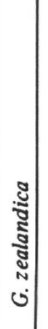 & के & 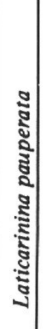 & 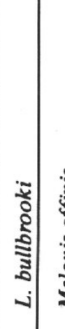 & 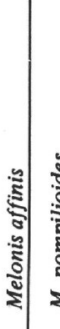 & 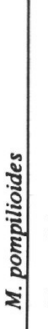 & 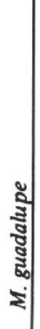 \\
\hline & & & 1 & 3 & $70-72$ & & & & & & & & & $\bullet$ & & & & & $\bullet$ & & $\bullet$ & & \begin{tabular}{l|l} 
& $\bullet$
\end{tabular} & 1. & $\bullet$ \\
\hline & & $\frac{\pi}{\pi}$ & 1 & & $\mathrm{CC}$ & & 2 & & & & & & & 498 & & & & & \begin{tabular}{|l|l}
13 \\
\end{tabular} & & 8 & & \begin{tabular}{l|l}
4 & 31 \\
\end{tabular} & \begin{tabular}{l|l}
12 \\
\end{tabular} & 24 \\
\hline & & & 2 & 2 & $70-72$ & & $\bullet$ & & & & & & & - & & & & & $\bullet$ & & $\cdot$ & & \begin{tabular}{l|l}
-1 & $\bullet$
\end{tabular} & 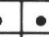 & $\cdot$ \\
\hline & & & 2 & & $\mathrm{CC}$ & & 2 & & & & & & & 36 & & & & & 3 & & 1 & & \begin{tabular}{l|l}
2 & 15 \\
\end{tabular} & \begin{tabular}{l|l}
5 & 9 \\
\end{tabular} & 9 \\
\hline & & $\overline{\widetilde{̣}}$ & 3 & 3 & $70-72$ & & $\therefore$ & $\mathrm{N}$ & & & & & & $\cdot 1$ & & & & & - & & - & & \begin{tabular}{l|l} 
- $\quad \bullet$ \\
\end{tabular} & 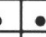 & $\bullet$ \\
\hline & & $z$ & 3 & & $\mathrm{CC}$ & & 3 & $\mathbf{N}$ & & & & & & 30 & & & & & 9 & & $\mathrm{~N}$ & & \begin{tabular}{l|l}
5 & 2 \\
\end{tabular} & 25 & 5 \\
\hline & - & $\frac{0}{7}$ & 4 & 3 & $70-72$ & & $\bullet$ & & & & & & & - & & & & & - & & & & & & - \\
\hline & 1 & z & $4^{4}$ & & $\mathrm{CC}$ & & 12 & 2 & & & $\mathrm{~N}$ & & & 2 & & & & & 4 & & $\mathrm{~N}$ & & & & 4 \\
\hline & & $\cong$ & & 5 & $70-72$ & & $\bullet$ & $\bullet$ & & & 5 & & & 4 & & & & & 2 & & 1 & & & & $\bullet$ \\
\hline & & $z$ & 5 & & $\mathrm{CC}^{\prime}$ & & 50 & 10 & & & 3 & & & 1 & & & & & 12 & & 2 & & & & 1 \\
\hline 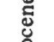 & $\Sigma$ & 9 & 6 & 3 & $100-102$ & & & & & & & & & & & & & & - & & & & & & \\
\hline$\stackrel{0}{\frac{0}{2}}$ & & $z$ & 6 & & $\mathrm{CC}$ & & 11 & 26 & & & 1 & & & 2 & & 2 & & & 10 & & & & & & \\
\hline & & $\infty$ & & 3 & $70-72$ & & & & & & $\cdot$ & & & & & $\bullet$ & & & $\bullet$ & & & & & & \\
\hline & & $z$ & 7 & & $\mathrm{CC}$ & & 13 & 8 & & & 1 & & & & & 4 & 1 & & 4 & & & 1 & & & \\
\hline & (⿻上丨) & & 8 & & $\mathrm{CC}$ & & 13 & 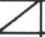 & & & $\mathrm{N}$ & & $\mathbf{N}$ & & & 6 & & & 3 & & & 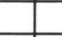 & & & \\
\hline & & 苂 & 9 & 3 & $70-72$ & & 18 & - & & & $\mathrm{N}$ & & & & & $\bullet$ & $\cdot$ & & $\cdot$ & & & 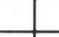 & & & \\
\hline & & & & & $\mathrm{CC}$ & & 24 & 14 & & & & & $\mathrm{~N}$ & & & 6 & 2 & & 11 & & & 1 & & & \\
\hline & & & 10 & 3 & $70-72$ & & & & & & & & - & & & & $\bullet$ & & $\bullet$ & & & - & & & \\
\hline & & $\tilde{\sim}$ & 10 & & $\mathrm{CC}$ & 48 & & 1 & & & & & 16 & & & & 4 & & \begin{tabular}{l|l}
34 \\
\end{tabular} & & & 2 & & & \\
\hline & & i & 11 & 5 & $68-70$ & 5 & & $\bullet$ & & & & & - & & & & $\bullet$ & & $\bullet$ & & & & & & \\
\hline & & & 11 & & $\mathrm{CC}$ & 47 & & 1 & & & & & 1 & & & & 3 & 2 & \begin{tabular}{l|l|}
13 \\
\end{tabular} & & & & & & \\
\hline & & & 12 & 3 & $70-72$ & & & & & & & & & & & & - & & $\bullet$ & & & & & & \\
\hline & $\cong$ & & & & $\mathrm{CC}$ & & & 3 & & & & & & & & & 1 & 3 & 2 & & & & & & \\
\hline & త్ & & 13 & 3 & $70-72$ & & & & & & & & & & & & - & & $\cdot$ & & & & & & \\
\hline & & & 13 & & $\mathrm{CC}$ & 13 & & & & & & & & & & & 1 & 1 & 11 & & & & & & \\
\hline & & $\stackrel{T}{a}$ & 14 & 3 & $70-72$ & & & & & & & & & & & & & & & & & & & & \\
\hline & & & 14 & & $\mathrm{CC}$ & 3 & & 1 & & & & & & & & & 2 & & 1 & & & & & & \\
\hline : & & & 15 & 3 & $70-72$ & & & & & & & & & & & & & & & & & & & & \\
\hline 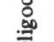 & & & 10 & & $\mathrm{CC}$ & 3 & & 1 & & 1 & & & & & & & 6 & & 1 & & & & & & \\
\hline$\overline{0}$ & & & 16 & & $\mathrm{CC}$ & 3 & & & & 1 & & & & & & & 1 & & 3 & & & & & & \\
\hline & & & 17 & & $\mathrm{CC}$ & $\mathrm{N}$ & & 5 & & 3 & & & & & & & 2 & & 2 & & & & & & \\
\hline & & 오 & 18 & & $\mathrm{CC}$ & $\mathrm{N}$ & & 2 & & & & & & & & & 10 & 1 & 2 & & & & & & \\
\hline & & 9 & 19 & & $\mathrm{CC}$ & 2 & & 2 & & 1 & & & & & & & 3 & & 7 & & & & & & \\
\hline & & i. & 20 & & $\mathrm{CC}$ & & & & & & & & & & & & & & & & & & & & \\
\hline & 命 & & 21 & 4 & $70-72$ & $\bullet$ & & & & & & & & & & & - & $\cdot$ & - & & & & & & \\
\hline & & & 21 & & $\mathrm{CC}$ & 2 & & & & 1 & & & & & & & 6 & & & & & & & & \\
\hline & & $\stackrel{\infty}{\longrightarrow}$ & 22 & & $\mathrm{CC}$ & & & & & & & & & & & & & & & & & & & & \\
\hline & & i & 23 & & $\mathrm{CC}$ & 1 & & & & & & & & & & & 2 & & & & & & & & \\
\hline & & & 24 & & $\mathrm{CC}$ & 7 & & & & & & 1 & & & & & 5 & & & $\mathrm{~N}$ & & & & & \\
\hline & - & P.16/17 & 27 & & $\mathrm{CC}$ & 13 & & & & & & 2 & & & 3 & & 18 & & $Z$ & 4 & & & & & \\
\hline & & $\simeq$ & 28 & & $\mathrm{CC}$ & 5 & & & & & & 1 & & & & & 10 & 3 & & & & & & & \\
\hline & & 2 & 29 & & $\mathrm{CC}$ & 2 & & & & & & & & & & & 8 & & & & & & & & \\
\hline : & 害 & \pm & 32 & & $\mathrm{CC}$ & 5 & & & & & & 1 & & & & & 3 & & & 2 & & & & & \\
\hline & $\frac{0}{2}$ & 2 & 33 & & $\mathrm{CC}$ & 6 & & & & & & & & & 2 & & 2 & & & 3 & & & & & \\
\hline & & $\dddot{m}$ & 34 & & $\mathrm{CC}$ & 4 & & & & & & 1 & & & 1 & & 5 & & & 1 & & & & & \\
\hline & & a & 35 & & $\mathrm{CC}$ & 7 & & & & & & & & & & & & & & & & & & & \\
\hline & & P.3 & 38 & & $\mathrm{CC}$ & & & & & & & & & & & & 4 & & & & & & & & \\
\hline ब & & บ & 39 & 1 & $120-122$ & & & & & & & & & & & & & & & & & & & & \\
\hline & & i & 39 & & $\mathrm{CC}$ & & & & & & & & & & & & & & & & & & & & \\
\hline
\end{tabular}


TABLE 1 - Continued

\begin{tabular}{|c|c|c|c|c|c|c|c|c|c|c|c|c|c|c|c|c|c|c|c|c|c|c|c|c|c|c|c|c|c|c|}
\hline & & I & & & $\underline{m}$ & $y$ & 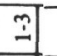 & & & $\cong$ & के & $\because$ & $\infty$ & a & & & & $=$ & & - & & + & $\simeq$ & $\cong$ & $a 1$ & to. & $\infty$ & - & & \\
\hline & & $\bar{N}$ & & & $m$ & $=$ & $n$ & & & $\infty$ & $a$ & $a$ & • & 0 & & & & $n$ & & $\backsim$ & & $n$ & $n$ & $n$ & $\omega$ & $\infty$ & $\infty$ & $\infty$ & & \\
\hline 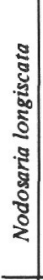 & 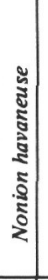 & 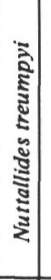 & 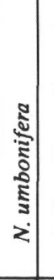 & 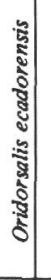 & 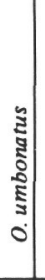 & 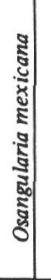 & 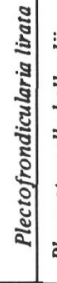 & 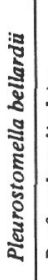 & 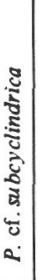 & 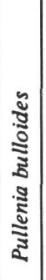 & 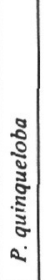 & 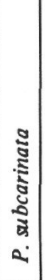 & 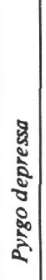 & 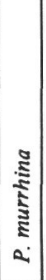 & 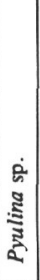 & 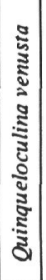 & 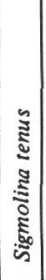 & 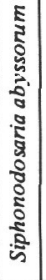 & 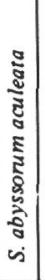 & 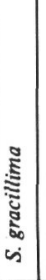 & 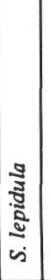 & 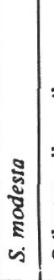 & 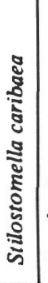 & 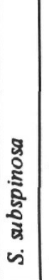 & 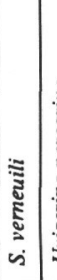 & 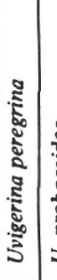 & 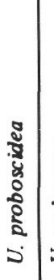 & 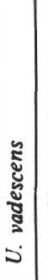 & 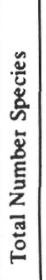 & 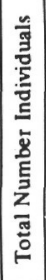 \\
\hline & & & & & - & & & & & $\bullet$ & $\bullet$ & $\bullet$ & $\bullet$ & $\bullet$ & & $\bullet$ & $\bullet$ & & & & & & & & & $\bullet$ & $\bullet$ & $\bullet$ & & \\
\hline & & & & & 21 & & & & & 8 & 4 & 10 & 42 & \begin{tabular}{|l|}
40 \\
\end{tabular} & & 18 & \begin{tabular}{|l|}
7 \\
\end{tabular} & & & & & & 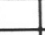 & 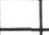 & & \begin{tabular}{|l|l}
117 & 1 \\
\end{tabular} & 12 & 4 & 47 & 730 \\
\hline & & & & & - & & & & & $\bullet$ & $\bullet$ & $\bullet$ & $\bullet$ & $\bullet$ & & $\bullet$ & $\bullet$ & & & & & & & 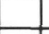 & & $\bullet$ & $\bullet$ & & & \\
\hline & & & & & 10 & & & & & 33 & 1 & 2 & 7 & 3 & & 2 & 2 & & & & & & & & & 4 & 3 & $\bullet$ & 36 & 160 \\
\hline & & & & & - & & & & & $\bullet$ & $\bullet$ & $\bullet$ & $\bullet$ & $\bullet$ & & & $\bullet$ & & & & & & L & - & & $\bullet$ & • & $\bullet$ & & \\
\hline & & & & & 21 & & & & & 7 & 2 & 2 & 31 & 2 & & 1 & $\mathrm{~N}$ & & & $\mathrm{~N}$ & 3 & & 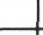 & 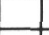 & & 4 & 5 & 2 & 39 & 617 \\
\hline & & & & & - & & & & & $\bullet$ & & $\bullet$ & $\bullet$ & $\bullet$ & & $\bullet$ & & & & & & & & & & $\mathrm{N}$ & & & & 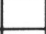 \\
\hline 3 & & & 3 & & 11 & & & & & 4 & & 3 & 12 & 2 & 3 & 6 & & & & 1 & & & $\angle$ & t & & $\mathrm{N}$ & $\mathrm{N}$ & $\mathrm{N}$ & 38 & 576 \\
\hline 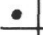 & & & $\bullet$ & & 2 & & & & & $\bullet$ & & & $\bullet$ & & $\bullet$ & & 2 & & & 2 & & & - & . & & & & & & \\
\hline 1 & & & 1 & & 4 & & & & & 1 & & 1 & 4 & $\angle$ & 2 & 1 & 2 & & & 4 & 1 & & 2 & 6 & & & & & 29 & 212 \\
\hline & & & $\bullet$ & \begin{tabular}{l|l}
8 & 1
\end{tabular} & 17 & & & & & & & & 4 & & • & & & & & - & & & • & & & & & & & \\
\hline & & & 2 & & 14 & & & & & 1 & & & 3 & 1 & & $\mathrm{~N}$ & & & & 12 & 2 & 1 & 3 & 2 & & & & & 45 & 200 \\
\hline & & & & & & & & & & & & & $\angle$ & & & & & & & $\bullet$ & & $\bullet$ & & 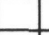 & & & & & 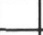 & \\
\hline & & & & & 7 & & & & & 1 & & & & & & & & & & 4 & & $\angle$ & & 1 & & & & & 31 & 204 \\
\hline & & & 4 & & & & & & & & & & $\angle$ & & & & & & & 2 & & 2 & & - & & & & & 23 & 241 \\
\hline & & & 2 & $\begin{array}{ll}2 & 1\end{array}$ & 14 & & & & & 2 & & & & & & & & & & $\bullet$ & & $\ldots$ & & - & & & & & . & - \\
\hline & & & $\mathrm{N}$ & & 4 & & & & 1 & 2 & & & & & & & & 2 & & 4 & & 1 & & - & & & & & 27 & 144 \\
\hline & & & & & - & & & & & & & & & & & & & & & & & & & 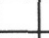 & & & & & & \\
\hline & & & & & 70 & & & & 1 & 3 & & & & & & & & 15 & & 6 & & & & 5 & & & & & 51 & 855 \\
\hline & & & & 2 & 9 & & & & & & & & & & & & & 1 & & 4 & & & & 33 & & & & & & \\
\hline & & & & & - & & & & 2 & & & & & & & & & 2 & & 2 & & & & 9 & & & & & 27 & 134 \\
\hline & & & & & 9 & & & & & $\bullet$ & & & & & & & & & & & & & & & & & & & & \\
\hline & & & & & - & & & & & 1 & & & & & & & & 1 & & 2 & & & & 32 & & & & & 36 & 244 \\
\hline & & & & & - & & & & & & & & & & & & & & & & & & & & & & & & & \\
\hline & & & & & 1 & & & & & 1 & & & & & & & & 33 & & 6 & & & & 10 & & & & & 42 & 307 \\
\hline & & & & & & & & & & & & & & & & & & & & & & & & & & & & & & \\
\hline & & & & & 9 & & & & & & & & & & & & & 7 & & 4 & & & & $\angle$ & & & & & 32 & 181 \\
\hline & & & & & 8 & & & & & & & & & & & & & & & & & & & 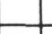 & & & & & & \\
\hline & & & & & 2 & 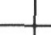 & & & & & & & & & & & & 29 & & & & & & 1 & 2 & & & & 36 & 231 \\
\hline & & & & & & & & & & & & & & & & & & $\angle$ & & & & & & 1 & 2 & & & & 26 & 132 \\
\hline & & & & & 15 & 3 & & & & & & & & & & & & $\angle$ & & & & & & 5 & & & & & 31 & 198 \\
\hline & & & & & 10 & & & & & & & & & & & & & & & & & & & 3 & 1 & & & & 18 & 164 \\
\hline & & & & & 15 & & & 2 & & & & & & & & & & & & & & & & & & & & & 29 & 131 \\
\hline & & & & & 6 & & & & & & & & & & & & & & & & & & & & $\angle$ & & & & 8 & 38 \\
\hline & & & & & - & & & - & & & & & & & & & & $\bullet$ & & & & & & & & & & & & \\
\hline & 3 & & & & 3 & & $\angle$ & & & & & & & & & & & 2 & $\bullet$ & & & & & & $\angle$ & & & & 32 & 139 \\
\hline & & & & & 1 & & & & & & & & & & & & & & & & & & & & & & & & 6 & 17 \\
\hline & 1 & & & & & & & & & & & & & & & & & 16 & 2 & & & & & & & & & & 15 & 34 \\
\hline & 7 & & & & 5 & & $\angle$ & & & & & & & & & & & 10 & & & & & & $\angle$ & & & & & 26 & 126 \\
\hline & 24 & 4 & & & 15 & 5 & & & & & & & & & & & & 11. & 27 & & & & & $\angle$ & 6 & & & & 52 & 974 \\
\hline & $\angle$ & 8 & & & 4 & 1 & & & & & & & & & & & & 8 & 15 & & & & & & 4 & & & & 28 & 164 \\
\hline & & 3 & & & & 4 & & & & & & & & & & & & $\angle$ & & & & & & & $\angle$ & & & & 27 & 314 \\
\hline & 4 & 12 & & & 5 & 2 & & & & & & & & & & & & 10 & 8 & & & & & & 3 & & & & 31 & 491 \\
\hline & 7 & 5 & & & 2 & 6 & & & & & & & & & & & & & $\angle$ & & & & & & $\angle$ & & & & 53 & 166 \\
\hline & & 4 & & & 7 & 3 & & & & & & & & & & & & & $\angle$ & & & & & & $\angle$ & & & & 40 & 573 \\
\hline & & 3 & & & 6 & 8 & & & & & & & & & & & & & 3 & & & & & & $\angle$ & & & & 27 & 411 \\
\hline & & & & & & & & & & & & & & & & & & & & & & & & & & & & & 47 & 569 \\
\hline & & & & & & & & & & & & & & & & & & & & & & & & & & & & & & \\
\hline & & & & & & & & & & & & & & & & & & & & & & & & & & & & & & 786 \\
\hline
\end{tabular}


TABLE 2

Stratigraphic Distribution and Relative Abundance of Benthonic Species at Site 171

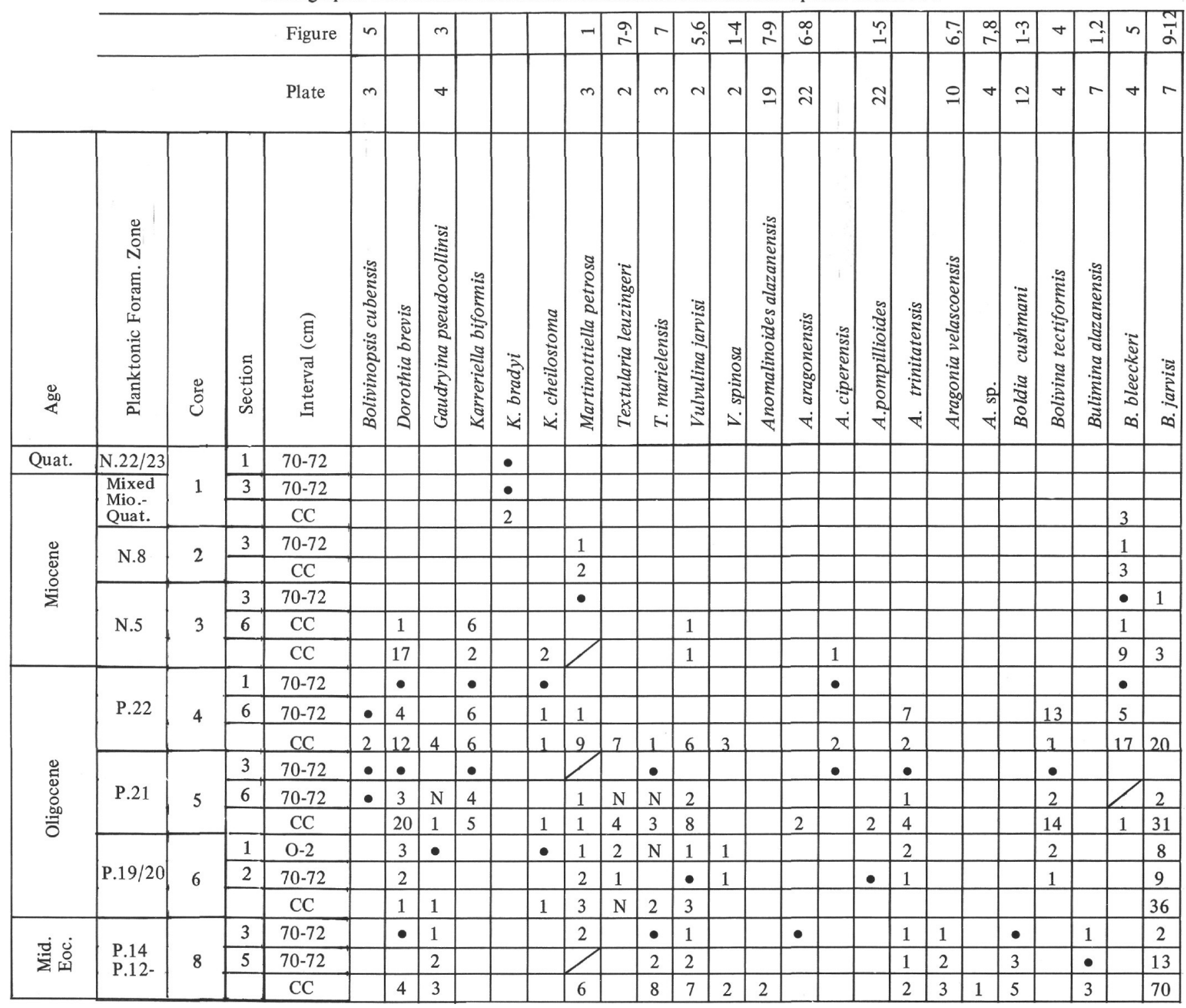

Note: See Table 1 for explanation of symbols.

\section{DISCUSSION}

Most of the more common benthic species at the studied sites can be divided into four stratigraphic groups:

1) Latest Cretaceous (mostly late Campanian or Maastrichtian) to Paleocene.

2) Eocene to early Oligocene.

3) Late Oligocene to middle Miocene.

4) Middle Miocene to Recent.

There is probably a fifth group which includes species that range from the Paleocene to middle Eocene which is not represented except for some middle Eocene occurrences. This group is largely absent because of a major early Tertiary hiatus at the two sites. A few species occur in more than one group. Most of these range from the Eocene to Neogene or Quaternary. There is very little species overlap between Group 1 and Group 4.
Latest Cretaceous and Paleocene assemblages contain numerous nodosariids and large populations of Gavelinella, Osangularia, and Gyroidinoides. In the Cretaceous Praebulimina, such as $P$. cushmani and $P$. cf. carseyae, are common. In the late Maastrichtian Bulimina trinitatensis and Quadratobuliminella cf. pyramidalis appear and appear to extend into the early Paleocene. Typical of deep-sea assemblages of this age are Aragonia and, in the Pacific, $A$. trinitatensis and $A$. velascoensis. Both species have broad distribution in the Caribbean and Mediterranean regions. Stilostomella and Pyramidina are present in samples from Site 171 but nearly absent in the much less well preserved sediments at Site 167 (Figure 3). In the Paleocene Anomalinoides begins to occupy the dominant position held by Gavelinella in the Cretaceous. It is likely that the large populations of these taxa are in part due to preferential preservation as these genera seem to be 
TABLE 2 - Continued

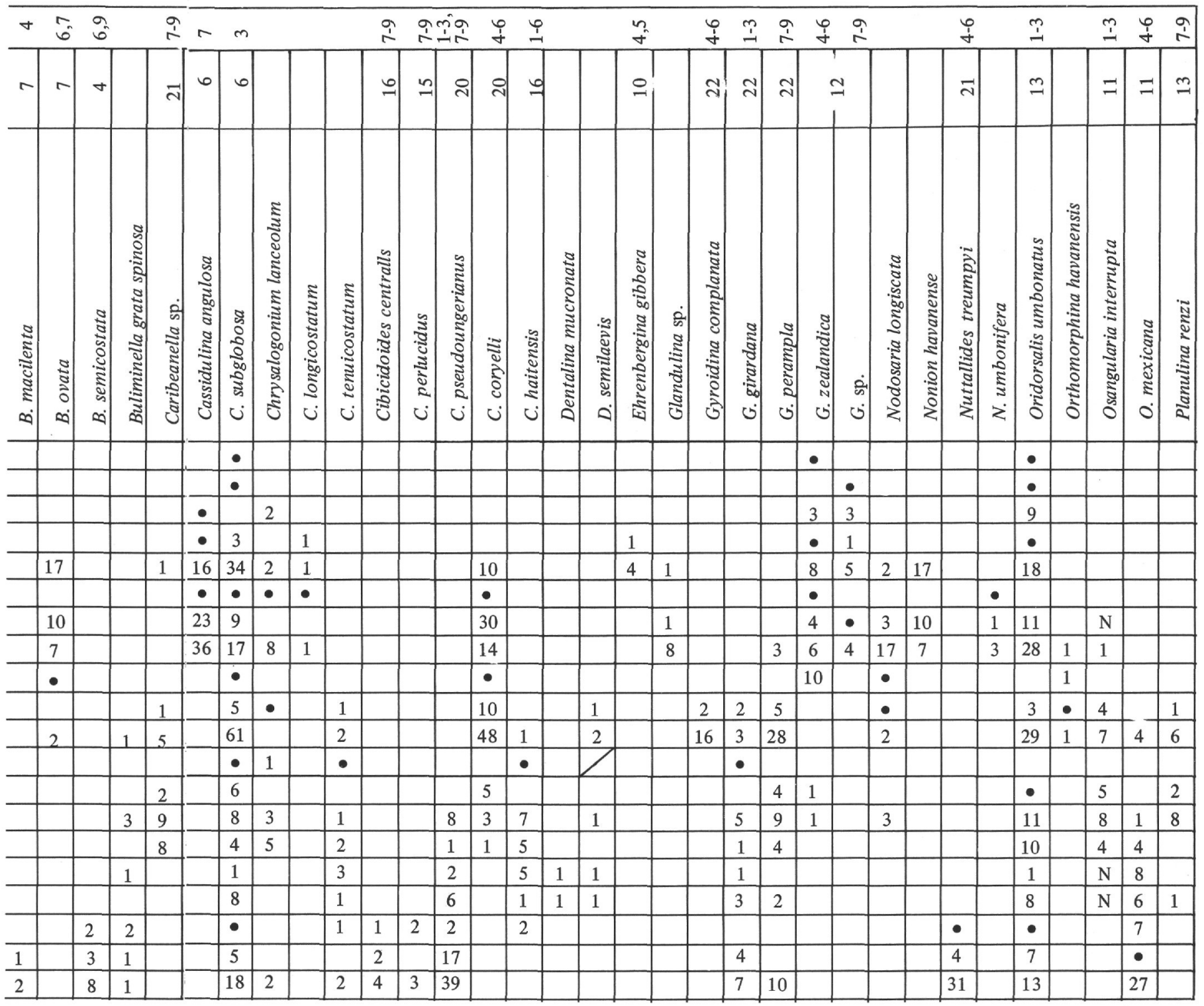

especially resistant to dissolution and breakage (due to compaction). Agglutinated species are not numerous nor very abundant at either site in the Cretaceous-again this may be due to preservation. Gaudryina is the most common genus and, at Site 167, Spiroplectammina is represented in several samples.

The Cretaceous faunas from the Horizon Guyot (Site 171) are similar to mid-latitude slope faunas in California (Sliter, 1968; Sliter and Baker, 1972) in the common occurrence of Praebulimina, Gyroidinoides, Osangularia, Pyramidina, Dorothia, and Gaudryina. There are, however, differences. Aragonia, a dominant taxa in deep-sea assemblages, is absent from California, and Pullenia and most of the agglutinated taxa common in California are absent or rare on Horizon Guyot. At the generic level, there is close resemblance to deep-sea faunas in the Atlantic (Fischer, 1969; Todd, 1970; unpublished data from Site
22). There are difficulties in comparing Site 167 with other areas because of the large amount of foraminigeral carbonate loss (see chapter 13). The Cretaceous assemblages are probably in large part residue assemblages. They are composed mostly of Osangularia, Gavelinella, Aragonia, Praebulimina, Gaudryina, fragments of Spiroplectammina, and rare occurrences of nodosariids and pleurostomellids. Despite the preservation problem, there are many taxa in common with slope faunas of California, particularly in the species of Osangularia, Gavelinella, Praebulinina, and Spiroplectammina.

Assemblages in the interval from the middle Eocene to early Miocene contain a much different group of genera. The dominant taxa are Cibicidoides, Gyroidina, Bulimina, and a few Cassidulina. Stilostomella and Siphonodosaria are common and frequently represented by numerous individuals and several species. Nodosariids, common in the 
TABLE 2 - Continued

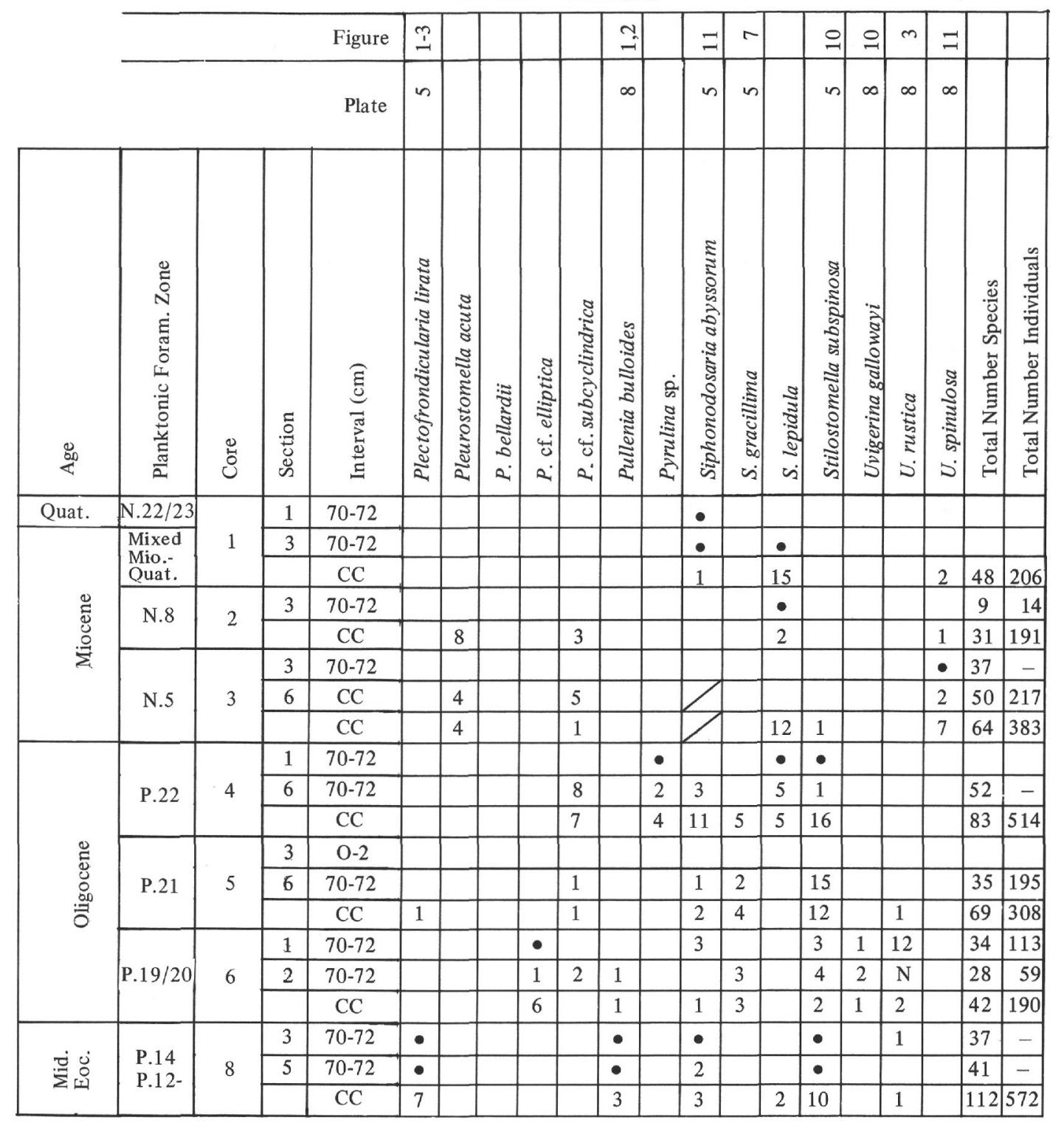

Cretaceous and Paleocene, are a rather minor faunal element. Lenticulina, Dentalina, and especially Chrysalogonium are most common. Chrysalogonium tenuicostatum was found in most Oligocene and better preserved late Eocene samples. The most common agglutinated taxa is Vulvalina but other genera, e.g., Karreriella, Bolivinopsis, and Dorothia, are usually present.

Within the Paleogene to earliest Neogene generic assemblage can be recognized two groups of species that were mentioned above: species which are either restricted to the Eocene or extend into the early Oligocene and species which originate in the Oligocene and range into the mid-Miocene. In both groups are many species that are well known in the Caribbean (e.g., Beckmann, 1953; Cushman and Stainforth, 1945) and in the Atlantic
(Berggren, 1972). Alabamina dissonata, Nuttallides truempyi, Bulimina macilenta, Anomalinoides aragonensis, and Cibicidoides centralis are restricted to Eocene (or earlier) sediments. Many of the species common in Eocene samples extend into the early Oligocene, such as Anomalinoides pompilioides, B. alazanensis, Ellipsoglandulina multicostata, Plectofrondicularia lirata, and Siphonodasaria abyssorum aculeata. The last appearance of $A$. dissonata and $N$. truempyi is in good agreement with planktonic foraminifera for identifying the top of the Eocene, but key Oligocene species appear in Zone P. 19/20 rather than near the base of the epoch. Several Oligocene species, including Cibicidoides havanensis, C. jarvisi, Bolivina tectiformis, Bulimina ovata, and Gyroidina complanata appear in Zones P. 19/20 or P. 21 and overlap the last occurrence of the common and 
TABLE 3

Interpretative Biostratigraphic Ranges of Common Benthonic Species from Sites 167 and 171

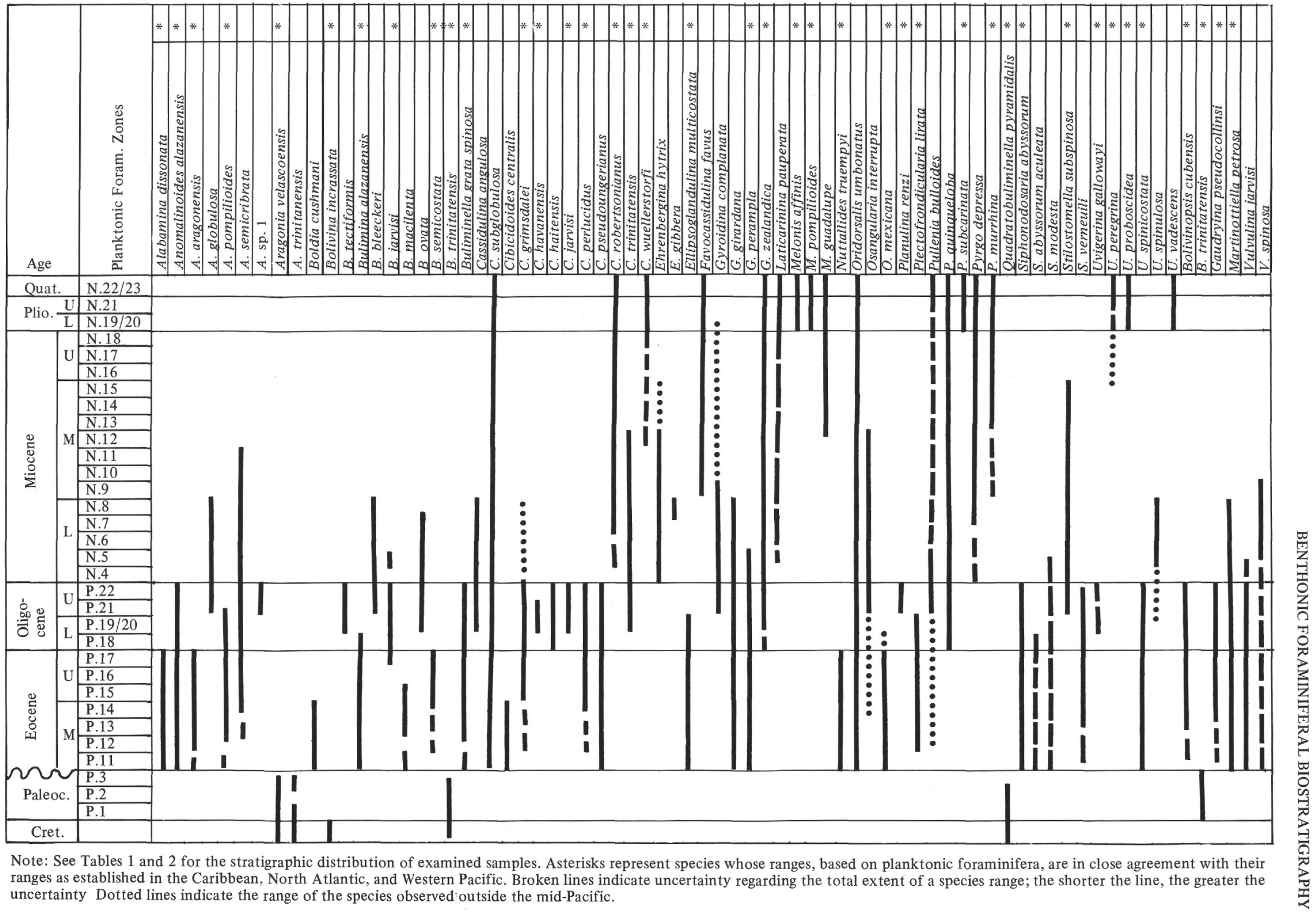


distinctive Eocene species Ellipsoglandulina multicostata and Plectofrondicularia lirata. Most of these Oligocene species range into the middle Miocene.

Eocene and Oligocene faunas in the mid-Pacific closely resemble the faunas found in the Oceanic Formation of Barbados (Beckmann, 1953). Many of the species from this classic, deep-water formation in the Caribbean are present at Sites 167 and 171, esepcially the dominant species of Cibicidoides, Bulimina, Gyroidina, Anomalinoides, Siphonodosaria, Stilostomella, and Vulvulina. Many of these same species also are present in the North Atlantic (Berggren, 1972) and in the Mediterranean (Berggren and Phillips, 1971). In the late Paleogene, deep-sea faunas seem to have had a cosmopolitan distribution at the species level that was not equaled in the late Neogene or Quaternary. Based on the planktonic foraminifera, many benthic species have the same stratigraphic range in the Atlantic, Caribbean, and Pacific. Such species include Bulimina jarvisi, B. alazanensis, Cibicidoides grimsdalei, C. havanenesis, C. jarvisi, C. pseudoungerianus, Vulvulina jarvisi, and Bolivinopsis cubensis; most are well-known stratigraphic markers.

Late Neogene and Quaternary assemblages are characterized by Melonis, Pullenia, Pyrgo, Uvigerina, Laticarinina, and a few cassidulines. Tire dominant genera of the Paleogene, Cibicidoides and Gyroidina, are represented by few species although frequently by large populations. By late Miocene time, mid-Pacific, deep-sea assemblages assume a fairly modern aspect, and species such as Cibicidoides wuellerstorfi, C. robertsonianus, Favocassidulina favus, and Uvigerina peregrina are well established. Melonis pompilioides, M. affinis, and U. probocidea appear in the Pliocene.

The Miocene assemblages in the mid-Pacific have species in common with those described by Parker (1964) from the experimental Mohole off Baja California and from the islands in the Western Pacific (Todd, 1966; 1964). Although the comparison is with faunas within the same ocean basin and presumably from about equal bathymetric environments, the similarities are not as great as between Paleogene faunas. Parker (1964) reports species of Fissurina, Pleurostomella, Epistominella, and nodosariids not found at Site 167.

The comparison with contemporaneous benthic assemblages in other areas of the Pacific and in the Caribbean and Atlantic suggests that the faunal changes observed at Sites 167 and 171 are due to widespread, evolutionary changes in deep-water faunas during the last 80 million years. Certainly, the faunal changes are difficult to account for based on the local history of subsidence which has occurred at the two sites. There is no evidence in the sedimentary or paleontological record to indicate that the Magellan Rise or Horizon Guyot have been in less than bathyal depths since the Campanian. This view is supported by back tracking the sites through time using the sea-floor age-depth curve of Sclater, Anderson, and Bell (1971) and the paleodepth method described by Berger and von Rad (1972). Based on this method, Site 167, which is located near the crest of Magellan Rise, was approximately 2500 meters deep by Campanian time. Its present depth is about 3200 meters. Horizon Guyot was apparently shallower, about 1500 meters deep in the Campanian. It is presently 2300 meters deep. The difference in depth between the two sites can be detected in the benthic assemblages. For example, in the Eocene and Oligocene, Bolivina, Plectofrondiculaira, and nodosariids are common on the Horizon Guyot, but rare or absent on the Magellan Rise. Anomalinoides, Bulmina, Osangularia, and Cibicidoides are more common on the Magellan Rise.

It is interesting to note that the times of major faunal turnover in benthic assemblages, in the late Eocene, earliest Miocene, and late Miocene, correspond closely to major changes in bottom temperatures (see Chapter 20, this volume). Oxygen-isotope paleotemperatures derived from mixed benthic foraminiferal assemblages indicate bottom temperatures of $12^{\circ} \mathrm{C}$ in the middle Eocene, followed by a sharp temperature decline in the late Eocene and early Oligocene. This seems to mark the end of many species which originated in the Paleocene or latest Cretaceous and their replacement by species belonging to Cibicidoides, Gyroidina, and other genera. Subsequently, there was a temperature increase in the latest Oligocene and early Miocene, culminating in the thermal maximum for the Neogene and Quaternary in the early middle Miocene. The middle Miocene marks the extinction of numerous species which evolved or appear in the central Pacific in the late Eocene or early Oligocene. Following the thermal maximum, there is a rapid decrease in temperatures from $8^{\circ} \mathrm{C}$ to the present-day value (around $1^{\circ} \mathrm{C}$ ) in approximately 14 million years. In the late Miocene, when this trend was well established, we see the appearance of modern deep-sea assemblages. The correlation between the changes in temperature and benthic assemblages suggests a cause and effect relationship. It is bathymetric migration. If this is so, one would expect that during times of declining bottom temperatures, as in the late Eocene-early Oligocene, there would be a progressive upslope migration of benthic foraminifera. Correspondingly, during times of increasing bottom temperatures, as in the early Miocene, there would be downslope migration of assemblages. Large, vertical migration of deep-sea faunas (which would include slope faunas) challenges the widely held notion that the bathymetric range of most benthic taxa has remained static. Invalidation of this assumption would require careful reinterpretation of paleobathymetric interpretations based upon benthonic foraminifera. For example, interpretation of slope-depth assemblages from a near-shore basin might appear to suggest a "regression" in late Eocene-early Oligocene time as faunas migrated upslope and a "transgression" in early Miocene time as faunas migrated downslope in response to temperature fluctuations. As faunas modernized in the late Neogene and Quaternary, the bathymetric error would diminish as the basis for direct comparison with Recent faunas increased.

\section{ACKNOWLEDGMENTS}

The author wishes to thank Mrs. Eva Topfl for aid in preparation of the samples and for compiling the data shown in Figures 1 to 3. Financial support for the scanning-electron photomicrographs and for preparation of the plates was provided in part by the Marathon Oil Company. Special thanks are extended to Mr. E. H. Ellis, Marathon Oil Company, who photographed the majority of the specimens illustrated in the faunal plates. 


\section{REFERENCES}

Beckmann, J., 1953. Die Foraminiferen der Oceanic Formation (Eocaen-Oligocenaen) von Barbadoes; Ecol. Geol. Hel., v. 46, p. 301-412.

Berger, W. H. and von Rad, U., 1972. Cretaceous and Cenozoic sediments from the Atlantic Ocean: Initial Reports of the Deep Sea Drilling Project, Volume XIV. Washington (U.S. Government Printing Office), p. 787-954.

Berggren, W. A., 1971. Cenozoic biostratigraphy and paleobiogeography of the North Atlantic: Initial Reports of the Deep Sea Drilling Project, Volume XII. Washington (U.S. Government Printing Office), p. 965-1002.

Berggren, W. A. and Phillips, J. D., 1971. Influence of continental drift on the distribution of Tertiary benthonic Foraminifera in the Caribbean and Mediterranean region: Geol. Libya Symp., University of Libya, p. 263-299.

Cushman, J. A., 1926. The Foraminifera of the Velasco Formation of the Tampico Embayment: Am. Assoc. Petrol. Geol. Bull., v. 10, p. 581-612.

Cushman, J. A. and Renz, H. H., 1946. The Foraminiferal Fauna of the Lizard Springs Formation of Trinidad, B.W.I.: Cushman Lab. Foram. Res. Spec. Publ., v. 18, p. 1-48.

1947. The Foraminiferal Fauna of the Oligocene Ste. Croix Formation of Trinidad, B.W.I.: Cushman Lab. Foram. Res. Spec. Publ., v. 22, p. 1-46.

1948. Eocene Foraminifera of the Navet and Hospital Hill Formations of Trinidad, B.W.I.: Cushman Lab. Foram. Res. Spec. Publ., v. 24, p. 1-42.

Cushman, J. A. and Stainforth, R. M., 1945. The Foraminifera of the Cipero Marl Formation of Trinidad, B.W.I.: Cushman Lab. Foram. Res. Spec. Publ., v. 14, p. 3-75.

Douglas, R. G. and Moullade, M., 1972. Age of the basal sediments on the Shatsky Rise, Western North Pacific Ocean: Geol. Soc. Am. Bull., v. 83, p. 1163-1168.

Fischer, M. J., 1969. Benthonic foraminifera from the Maastrichtian Chalk of Galicia Bank, west of Spain: Paleontology, v. 12, p. 189-200.

Hedberg, H. D., 1937. Foraminifera from the Middle Tertiary Carapita Formation of northeastern Venezuela: J. Paleont., v. 11, p. 661-697.

Loeblich, A. R. and Tappan, H., 1964. Protista 2: Sorcodina, Chiefly "Thecamoebians" and Foraminiferida: Treatise Invert. Paleont., v. C, 900 p.
Luterbacher, H., 1972. Foraminifera from the lower Cretaceous and Upper Jurassic of the northwestern Atlantic: Initial Reports of the Deep Sea Drilling Project, Volume XI. Washington (U.S. Government Printing Office), p. 561-593.

Maync, W., 1973. Lower Cretaceous foraminiferal fauna from Gorringe Bank, eastern North Atlantic: Initial Reports of the Deep Sea Drilling Project, Volume XIII. Washington (U.S. Government Printing Office), p. 1075-1111.

Nuttall, W. L. F., 1932. Lower Oligocene Foraminifera from Mexico: J. Paleont., v. 6, p. 3-35.

Parker, F. L., 1964. Foraminifera from the experimental Mohole drilling near Guadalupe Island, Mexico: J. Paleont., v. 38, p. 617-636.

Parker, F. L. and Berger, W. H., 1971. Faunal and solution patterns of planktonic foraminifera in surface sediments of the South Pacific: Deep-Sea Res., v. 18, p. 73-107.

Peterson, M. N. A., et al., 1970. Initial Reports of the Deep Sea Drilling Project, Volume II. Washington (U. S. Government Printing Office).

Sclater, J. G., Anderson, R. N., and Bell, M. L., 1971. Elevation of Ridges and Evolution of the central eastern Pacific: J. Geophys. Res., v. 76, p. 7888-7893.

Scott, W., 1935. Die foraminiferen in dem aquatorialen Teil des Atlantischen Ozeans: Wiss. Ergebn. Dt. Atlant. Exped. "Meteor", v. 3, Abt B, p. 43-134.

1966. Foraminiferen fauna und stratigraphie der Tiefsee-Sedimente im nordatlantischen Ozean: Swed. Deep-Sea Exped. Rept., v. 7, p. 357-469.

Sliter, W. V., 1968. Upper Cretaceous foraminifera from southern California and northwestern Baja California: Kansas Univ. Paleont. Contr., v. 49, p. 1-141. 1971. Predation of benthic foraminifera: J. Foram. Res., v. 1, p. 20-29.

Sliter, W. V. and Baker, R. A., 1972. Cretaceous bathymetric distribution of benthic foraminifera: J. Foram. Res. v. 2, p. 167-183.

Thiede, J., 1971. Planktonische Foraminiferen in sedimenten vom ibero-marokkanischen kontinentalrand: "Meteor" Forsch. Erebnisse., v. C (7), p. 15-102.

Todd, R., 1964. Smaller Foraminifera from the Late Tertiary of southern Okinawa: U. S. Geol. Survey Prof. Paper, 454-F.

1966. Smaller Foraminifera from Guam: U. S. Geol. Survey Prof. Paper, 403-I.

1970. Maastrichtian (Late Cretaceous) Foraminifera from a deep-sea core off southwest Africa: Rev. Espanol. Micropaleontol., v. 2, p. 17-34. 


\section{PLATE 1}

Examples of borings and other types of shell predation.

All specimens from Site 171-2, CC.

Figures 1-3 Siphonodosaria abyssorum (Brady).

1. Close-up view of hole on extreme right side of view in Figure 2. Note that hole is straight sided and essentially perpendicular to surface. The incompletely cut portion suggests that the hole was created by cutting away a single piece of shell material rather than by grinding. $\times 500$

2. Distal chamber of specimen showing typical type of shell boring. $\times 50$

3. Close-up view of hole on upper left hand of specimen in Figure 2. As in Figure 1, hole is roughly elliptical in outline and straight sided. This is the typical shape of most holes which appear to have been cut. $\times 750$

Figures 4, $5 \quad$ Stilostomella spp.

4. Apertural end of specimen showing multiple sets of shell borings. $\times 35$

5. Close-up view of hole on the neck of second chamber in Figure 4. Hole is similar to those in Figures 1-3 except in outline. $\times 250$

Figures 6, $7 \quad$ Astacolus sp.

6. Distal portion of shell showing the effects of shell corrosion. $\times 50$

7. Detail of surface in Figure 6. View is from about the center of Figure 6. This type of shell corrosion is often limited to initial chambers or to shell thickenings, such as bosses or plugs. $\times 250$

Figures 8, 9 Pullenia sp.

8. Circular pattern of holes developed on shell. $\times 50$

9. Close-up view of holes and incomplete boring. Note holes are enlarged at the top, generally not straight sided as in Figures 1 and 3. X500

Figures 10-13 Dentalina sp.

10. Shell showing multiple borings in each chamber. $\times 15$

11. Close-up view of large holes visible in Figure 11. Note holes have been bored at an angle to the surface of the test. $\times 500$

12. Close-up view of different set of holes than shown in Figure 11, smaller in diameter and bored perpendicular to shell surface. $\times 750$

13. Close-up view of third set of holes: Relative size can be estimated from distance between ribs compared to rib width shown in Figure 13. $\times 1500$ 

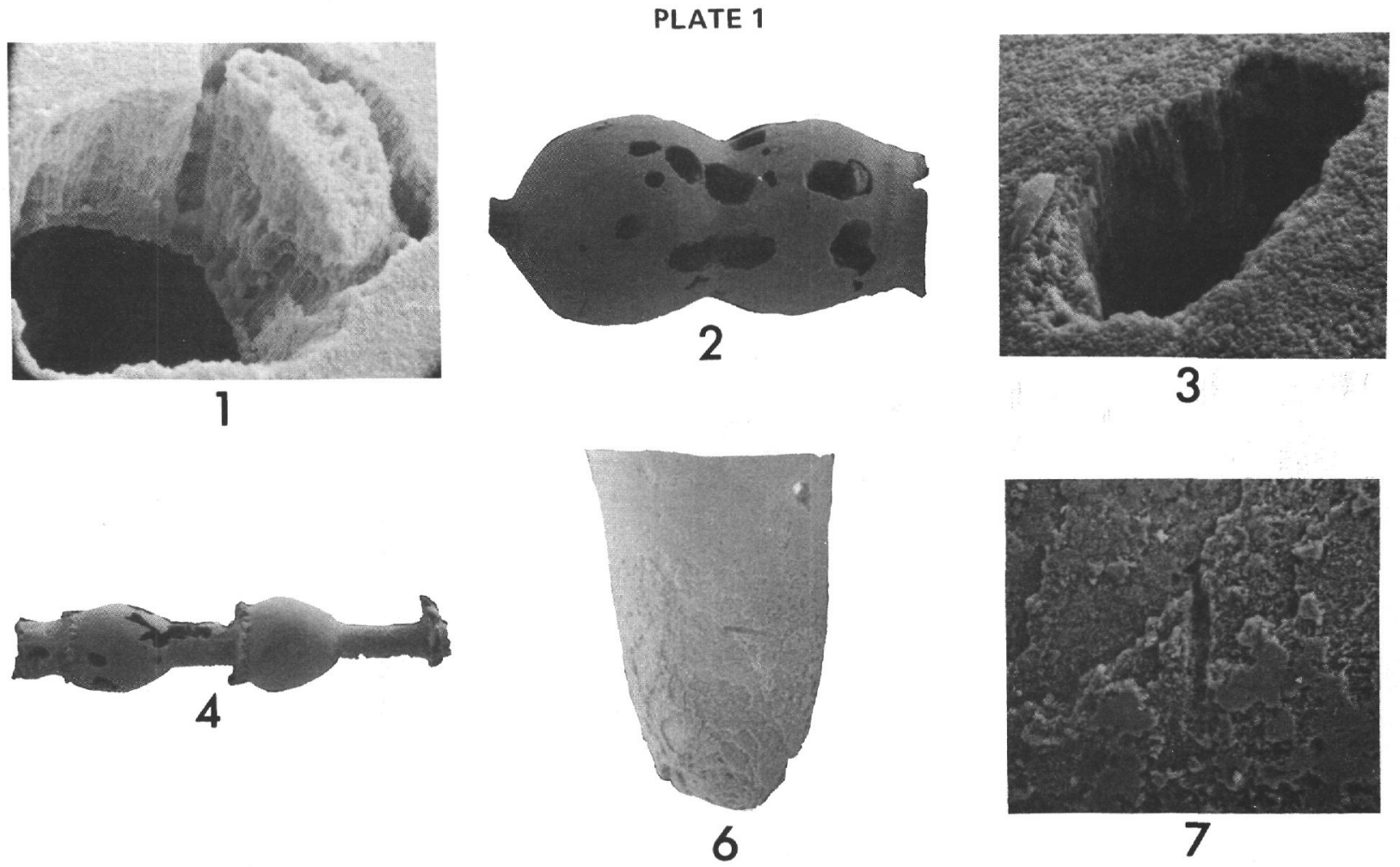

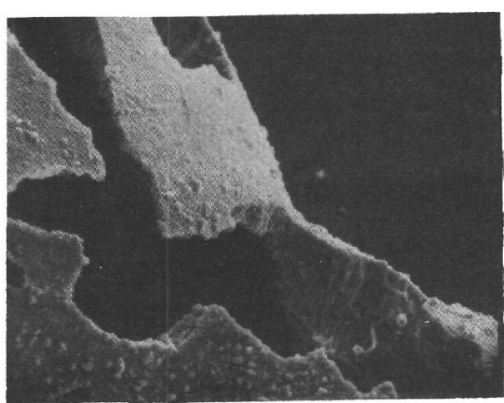

5

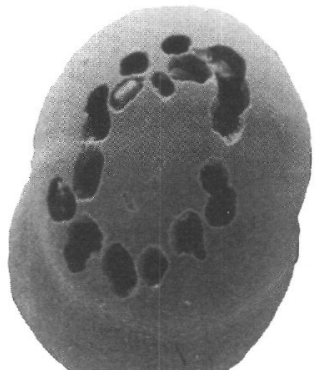

8

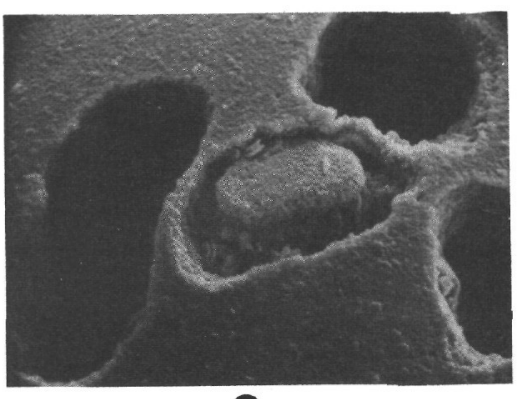

9

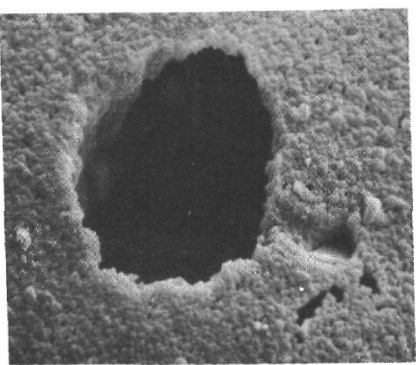

12

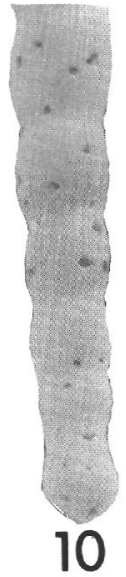

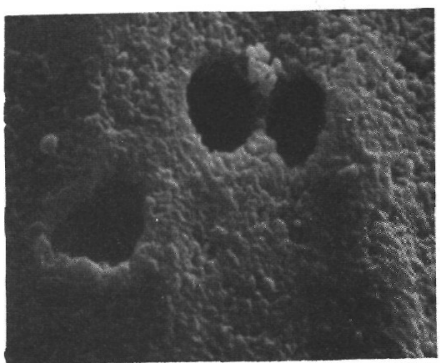

13

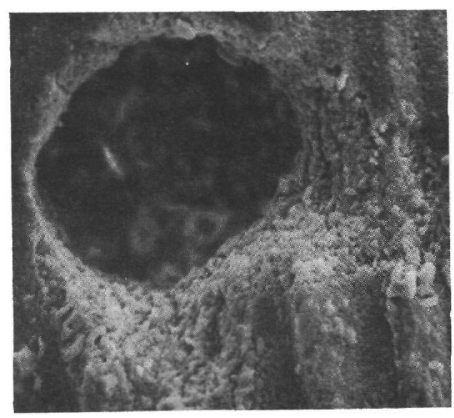

11 


\section{PLATE 2}

Figures 1-4 Vulvulina spinosa Cushman, 1927, Cushman Lab. Foram. Res. Contr., v. 3, p. 111, pl. 23, fig. 1. Middle Miocene-Middle Eocene,

1,2 Length of specimen, 0.80 and $1.20 \mathrm{~mm}$, respectively. Adult microspheric forms with spines at the basal peripheral angle of most chambers.

3,4. Length of specimens, $0.56 \mathrm{~mm}$ and $0.76 \mathrm{~mm}$, respectively. Juvenile biserial forms which resemble Spiroplectammina excolta Cushman with spines restricted to the outer pairs of chambers.

Figures 5, 6 Vulvulina jarvisi Cushman, 1932. Cushman Lab. Foram. Res., Contr., v. 8, p. 84, pl. 10, fig. 10. Late Oligocene (? Early Miocene)-Eocene

5. Adult megalospheric form. Length of specimen $0.80 \mathrm{~mm}$.

6. Adult microspheric form. Length of specimen $1.52 \mathrm{~mm}$.

Vulvulina spinosa Cushman and Vulvulina jarvisi Cushman. All figured specimens from Sample 167-27, CC. Vulvulina spinosa and V. jarvisi are quite variable and difficult to separate, especially the "juvenile" biserial forms. Vulvulina spinosa is distinguished here as possessing prominent peripheral spines in the uniserial portion of the shell, while $V$. jarvisi lacks prominent spines though a few weak spines may develop. Also, the biserial portion of $V$. jarvisi is flat sided, whereas $V$. spinosa is biconvex.

Figures 7-9 Textularia leuzingeri Cushman and Renz, 1941, Cushman Lab. Foram. Res. Contr., v. 17, p. 3, pl. 1, fig. 2. Early Oligocene.

7. Adult form. Length of specimen, $1.20 \mathrm{~mm}$, Sample 171-4-CC. All individuals examined contained predation holes, similar to those in the figure, usually with one or more holes per chamber. The holes are presumably caused by nematodes.

8,9 . Details of the surface texture on the last formed chamber. Note that the shell is constructed predominantely of nannofossil debris. In the early formed chambers foraminiferal fragments and nannofossils occur in about equal amounts. However, in the later chambers the shell is constructed almost exclusively of Coccolithus pelagicus. Other smoothed surface species of Textularia, Spiroplectammina, and Karreriella exhibit considerable selectivity in test building materials. With of view, $0.12 \mathrm{~mm}$., $0.043 \mathrm{~mm}$., respectively. 


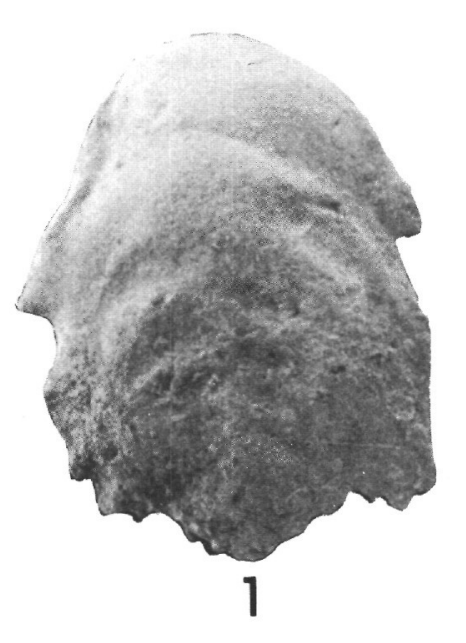

PLATE 2
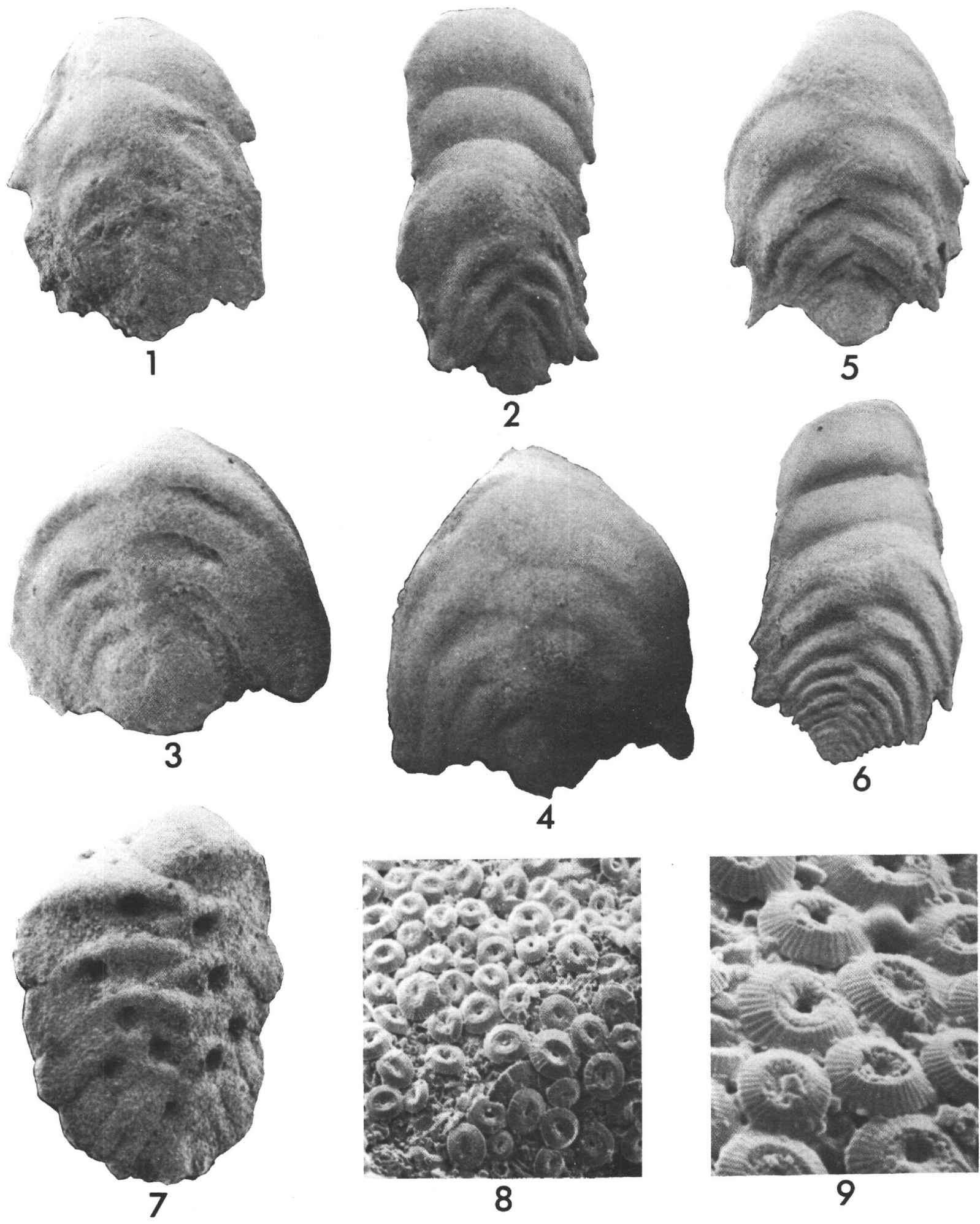


\section{PLATE 3}

Figure 1 Martinottiella petrosa (Cushman and Bermudez). Listerella petrosa Cushman and Bermudez, 1937, Cushman Lab. Foram. Res. Contr., v. 13, p. 5, pl. 1, figs. 24-26. Middle Miocene-Eocene. Typical adult form. Length of specimen, $1.36 \mathrm{~mm}$, Sample 171-4, CC.

Figures 2, 3 Haplophragmoides sp. Early Miocene-Late Oligocene. Maximum diameter of specimen, $0.52 \mathrm{~mm}$. Sample $167-9-3,70-72 \mathrm{~cm}$. The presence of a single, marginal aperture and simple interior septa indicates that the species is a Haplophragmoides, rather than a Cyclammina. The species is similar to $H$. cf carinatum Cushman and Renz figured by Beckmann (1953), but the periphery is more rounded.

Figure 4 Bolivinopsis trinitatensis (Cushman and Renz). Spiroplectammina trinitatensis Cushman and Renz, 1948, Cushman Lab. Foram. Res. Spec. Publ., v. 24, p. 11, pl. 2, figs. 13, 14. Eocene-Paleocene. Length of specimen, $0.40 \mathrm{~mm}$, Sample 167-27-CC. The species is restricted to Eocene samples from Site 167. Only the megalospheric forms of the species were found in the examined samples.

Figure 5 Bolivinopsis cubensis (Cushman and Bermudez). Spiroplectoides cubensis Cushman and Bermudez, 1937, Cushman Lab. Foram. Res. Contr., v. 13, p. 13, pl. 1, figs. 44-46. Oligocene-Eocene. Length of specimen, $0.64 \mathrm{~mm}$, Sample 167-10-CC. The species was originally described from the Eocene of Cuba, but it is found only in Oligocene samples at Sites 167. Its absence in older sediments is believed to be due to preservation. The species occurs in the middle Eocene at Site 171.

Figure 6 Spiroplectammina sp. Length of specimen, $1.36 \mathrm{~mm}$, Sample 171-9-1, 70-72 cm. This distinctive species is present in late Campanian and Maastrichtian samples from Site 171 .

Figure 7 Textularia marielensis Lalicker and Bermudez, 1938, J. Paleont., v. 12, p. 170, pl. 20, figs. 1,2. OligoceneLate Eocene. Length of specimen, $0.44 \mathrm{~mm}$, Sample 171-8-6, 70-72 cm. The rapid increase in thickness of the test, the flat apertural face, flush sutures, and smooth periphery distinguish this species from Textularia leuzingeri.

Figure 8 Trochamminoides irregularis White, 1928, J. Paleont., v. 2, p. 307, pl. 42, fig. 1. Early Miocene-Late Oligocene. Length of specimen, $0.92 \mathrm{~mm}$, Sample 171-8-CC. 
PLATE 3

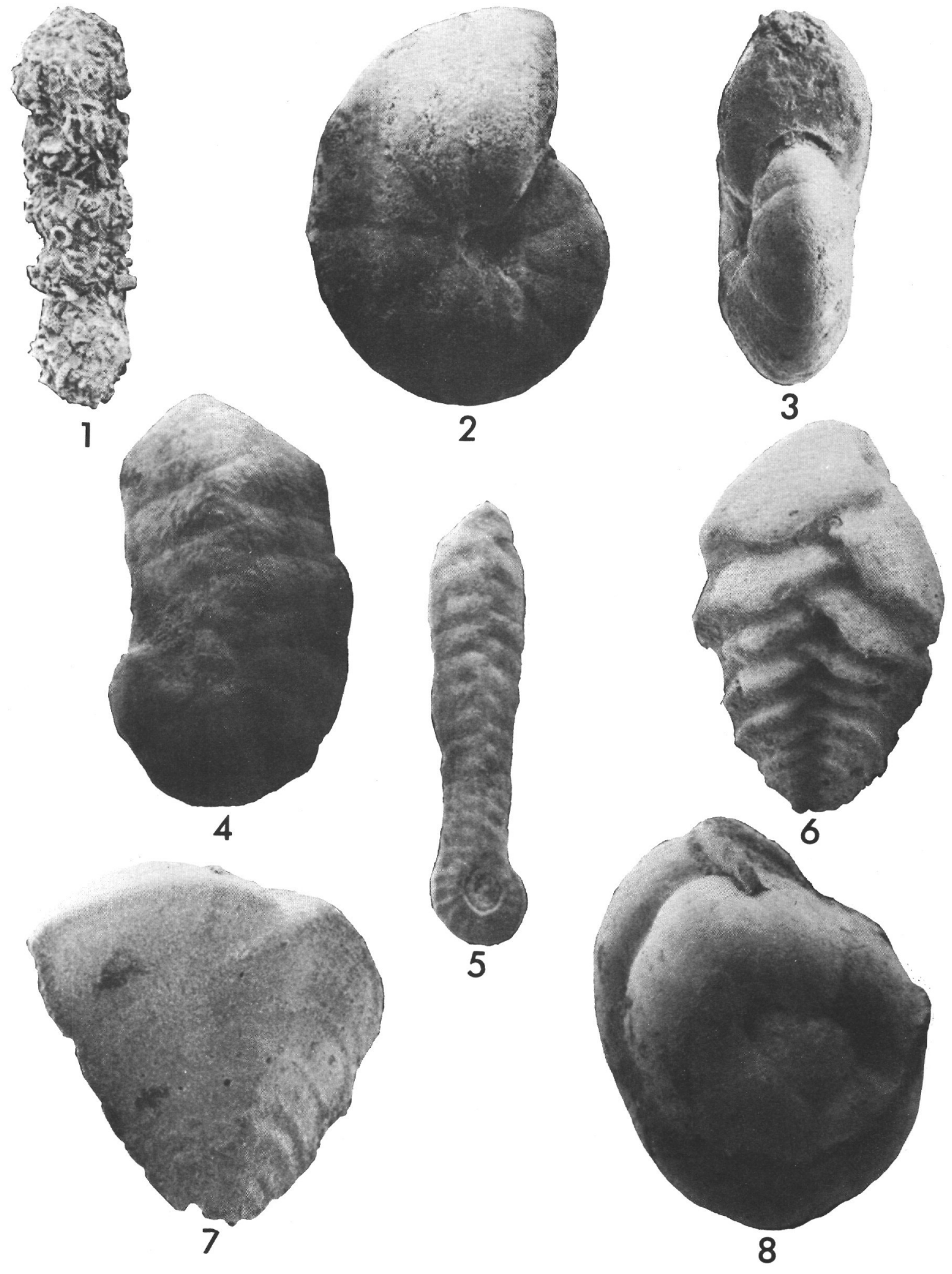




\section{PLATE 4}

Figure $1 \quad$ Karreriella alticamera Cushman and Stainforth, 1945, Cushman Lab. Foram. Res. Spec. Publ., v. 14, p. 19, pl. 2, fig. 10. Oligocene, Length of specimen, $1.0 \mathrm{~mm}$; width, $0.64 \mathrm{~mm}$, Sample 167-10-CC. The species is similar to $K$. bradyi Cushman, but has fewer chambers, and the final chamber projects distinctly above the previous one. The specimen figured as $K$. biformis by Beckman (1953, pl. 17, fig. 17) is probably the same as the Pacific species.

Figure 2 Eggerella sp. Eocene. Length of specimen, $0.80 \mathrm{~mm}$; width, $0.64 \mathrm{~mm}$, Sample 167-27-CC. The species is similar to E. propinqua (H. B. Brady) of Bermudez (1949), but it is more circular in cross-section and has less distinctive sutures. A total of about eight specimens were found in Eocene samples at Site 167.

Figure 3 Gaudryina pseudocollinsi Cushman and Stainforth, 1945, Cushman Lab. Foram. Res. Spec. Publ., v. 14, pl 2, figs. 1-3. Oligocene-Eocene, Length of specimen, $1.20 \mathrm{~mm}$; width, $0.68 \mathrm{~mm}$, Sample 167-27-CC. The variety referred to as $G$. pseudocollinsi primitiva Cushman and Renz (1948) and the typical forms of the species both occur in the same samples at Sites 167 and 171.

Figure 4 Bolivina tectiformis Cushman, 1926, Cushman Lab. Foram. Res. Contr., v. 1, p. 83, pl. 12, fig. 6. Oligocene, Length of specimen, $0.64 \mathrm{~mm}$; width, $0.20 \mathrm{~mm}$, Sample 171-5-CC. The species only occur at Site 171 . The ribs on the early portion of the shell and the large pores located along the sutures readily distinguish the species.

Figure 5 Bulimina bleeckeri Hedberg, 1937. J. Paleont., v. 11, p. 675, pl.91, figs. 12, 13. Miocene-Oligocene. Length of specimen, $0.38 \mathrm{~mm}$; width, $0.28 \mathrm{~mm}$, Sample 171-4-CC. This species occurs sporadically at both Sites 167 and 171. Scanning electron photomicrographs reveal that the species has a distinctive pattern of pores and imperforate spines.

Figures 6,9 Bulimina semicostata Nuttall, 1930, J. Paleont., v. 4, p. 274, p. 285, pl. 23, figs. 15, 16. Oligocene-Eocene.

6. Adult specimen. Length of specimen, $1.44 \mathrm{~mm}$; width, $0.18 \mathrm{~mm}$.

9. Detail of ribs and chamber surface, width of view $0.06 \mathrm{~mm}$. The lower half of the shell is covered by 20-30 gently curved or sinuous ribs. The species is most common in Eocene samples at Site 171.

Figures 7,8 Aragonia trinitatensis (Cushman and Jarvis). Bolivina trinitatensis Cushman and Jarvis, 1928, Cushman Lab. Foram. Res. Contr., v. 4, p. 99, pl.14, fig. 10. Paleocene-Maastrichtian. This species is easily distinguished from $A$. velascoensis by its shorter length, greater thickness, and highly elevated sutures. The species is widely distributed in deep-water facies in tropical regions.

7. Detail of surface and elevated sutures. Width of view $0.10 \mathrm{~mm}$.

9. Adult specimen. Length of specimen, $0.28 \mathrm{~mm}$; width, $0.26 \mathrm{~mm}$. 


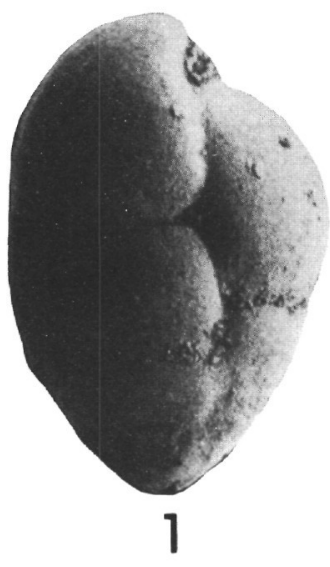

Plate 4
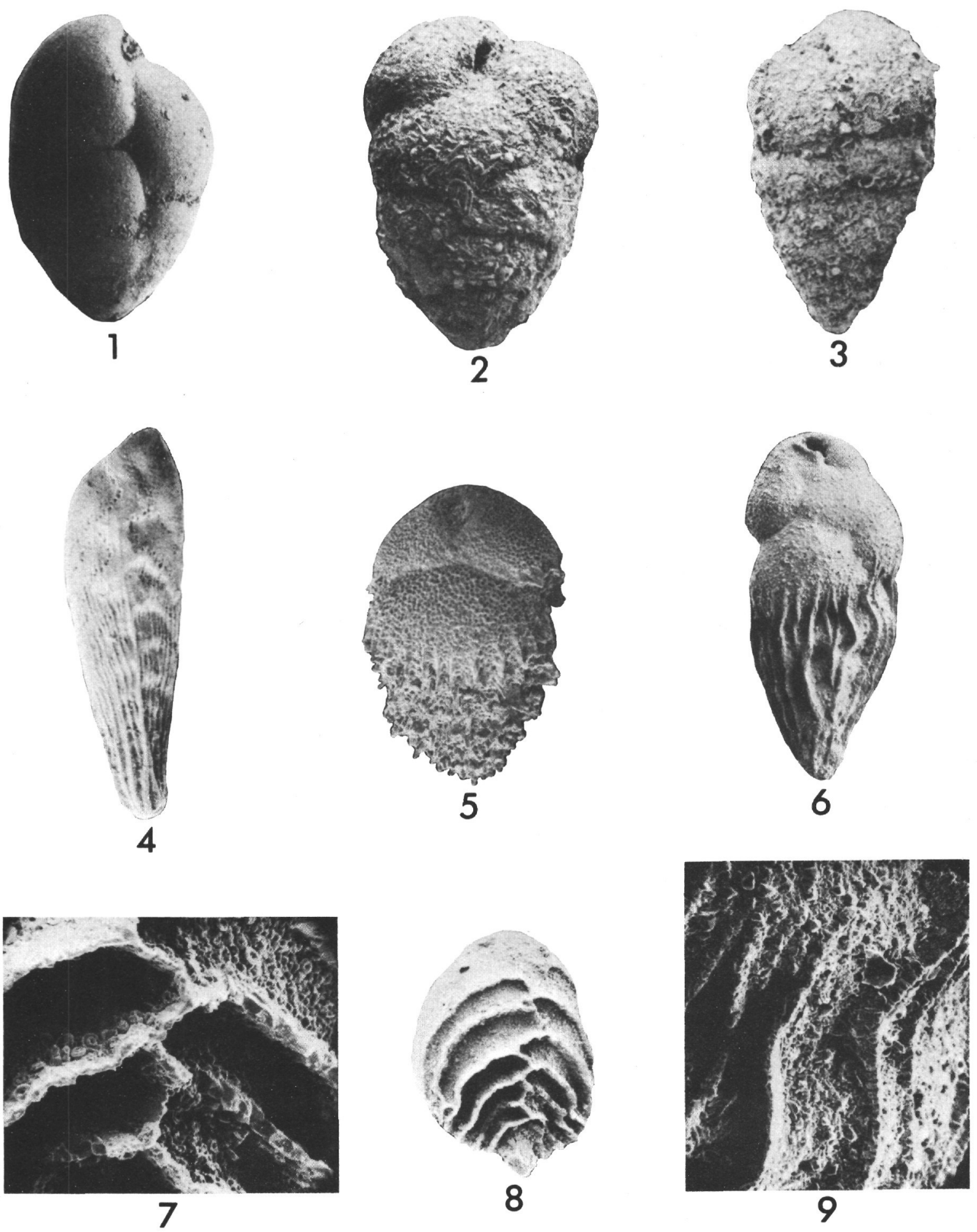


\section{PLATE 5}

Figures 1,2 Plectofrondicularia lirata Bermudez, 1937, Mem. Soc. Cubana Hist. Nat., v. 11, p. 240, pl. 20, fig. 6. Early Oligocene-Eocene. Both specimens from Sample 171-8-CC. The species is readily distinguished by the prominent longitudinal ribs which cover all but the last formed chamber. The number and thickness of the ribs is variable. In larger, longer specimens, the shell is gently twisted about the long axis.

1. Length of specimen, $1.72 \mathrm{~mm}$; width, $0.36 \mathrm{~mm}$.

2. Length of specimen, $1.67 \mathrm{~mm}$; width, $0.37 \mathrm{~mm}$.

Figure 3

Plectofrondicularia sp. Eocene. Length of specimen, $1.84 \mathrm{~mm}$; width, $0.56 \mathrm{~mm}$, Sample 171-8-CC. The species differs from $P$. lirata Bermudez in lacking prominent longitudinal ribs. Earlier chambers have a rectangular cross-section and weak, marginal keels.

Figure 4 Siphonodosaria modesta (Bermudez). Ellipsonodosaria modesta Bermudez, 1937, Mem. Soc. Cubana Hist. Nat., v. 11, p. 238, pl. 20, fig. 3. Miocene-Eocene. Length of specimen, $0.76 \mathrm{~mm}$; width, $0.12 \mathrm{~mm}$, Sample 171-3-CC. The species is found only in Miocene samples at Sites 167 and 171 .

Figures 5, 6 Bolivina incrassata Reuss, 1851, Haedingeis Naturwiss. Abh., v.4, p. 29, pl.5, fig. 13. Late Campanian-Maastrichtian. Both specimens from Sample 171-9-6, 0.4 cm. This species is widely distributed in Maastrichtian deep-sea sediments in the Pacific and Atlantic. It is most numerous at Site 171.

5. Microspheric adult. Length, $1.24 \mathrm{~mm}$; width, $0.30 \mathrm{~mm}$.

6. Megalospheric adult. Length, $1.32 \mathrm{~mm}$; width, $0.40 \mathrm{~mm}$.

Figure 7 Siphonodosaria gracillima (Cushman and Jarvis). Ellipsonodosaria nuttalli var gracillima Cushman and Jarvis, 1934, Cushman Lab. Foram. Res. Contr., v. 10, p. 72, pl. 10, fig. 7. Miocene-Oligocene. Length of specimen $1.32 \mathrm{~mm}$; width $0.24 \mathrm{~mm}$, Sample 167-6-CC. The megalospheric individuals usually have a basal spine, but the spine is lacking in microspheric forms. Chamber spines are arranged in a band around the base of each chamber in the early chambers, but cover the entire surface of the last two or three chambers. The spines are long and delicate and are directed toward the base of the shell.

Figure 8 Ellipsoglandulina multicostata (Galloway and Moorey). Daucina multicostata Galloway and Morrey, 1929, Am. Paleont. Bull., v. 15, p. 42, pl. 6, fig. 13. Early Oligocene-Eocene. Length of specimen, $0.84 \mathrm{~mm}$; width, $0.32 \mathrm{~mm}$, Sample 167-27-CC.

Figure 9 Stilostomella verneuili (d'Orbigny). Dentalina verneuili d'Orbigny, 1846, Foram. Foss. Bass. Tert. Vienne, p. 48, pl. 48, figs. 7, 8. Oligocene-Eocene. Length of specimen, $6.72 \mathrm{~mm}$; width, $1.11 \mathrm{~mm}$, Sample 167-27-CC.

Figure 10 Stilostomella subspinosa (Cushman). Ellipsonodosaria subspinosa Cushman, 1943, Cushman Lab. Foram. Res. Contr., v. 19, p. 92, pl. 16, figs. 6, 7. Miocene-Oligocene. Length of specimen, $1.20 \mathrm{~mm}$; width, $0.24 \mathrm{~mm}$, Sample $171-4 \mathrm{CC}$. The species tends to break at the narrow neck between chambers, and whole specimens are rare. The disarticulated chambers are difficult to distinguish from several other similar species.

Figure 11 Siphonodosaria abyssorum (Brady). Nodosaria abyssorum Brady, 1881, Quat. J. Micr. Sci., v. 21 , p. 31-71; Repts. Voy. Challenger 1873-1876, v. 9, p. 584, pl. 63, figs. 8, 9. MioceneEocene. Length of specimen, $3.20 \mathrm{~mm}$; width, $0.44 \mathrm{~mm}$, Sample 171-4, CC. Both the typical form and S. abyssorum var. aculeata (Cushman and Renz) occur in the Central Pacific. The variety has short spines on the last two or three chambers and prominent basal spines; it occurs in Eocene and earliest Oligocene samples. This species is the most common rectilinear-shaped species in the examined samples.

Figure 12. Stilostomella caribaea (Palmer and Bermudez). Ellipsonodosaria caribaea Palmer and Bermudez, 1936, Mem. Soc. Cubana Hist. Nat., v. 10, p. 297, pl. 18, figs. 10, 11. Miocene-Oligocene. Length of specimen, $1.28 \mathrm{~mm}$; width, $0.24 \mathrm{~mm}$, Sample 167-6-CC. The species was described from the Oligocene of Cuba, but it was only found in Miocene samples in the Pacific. 

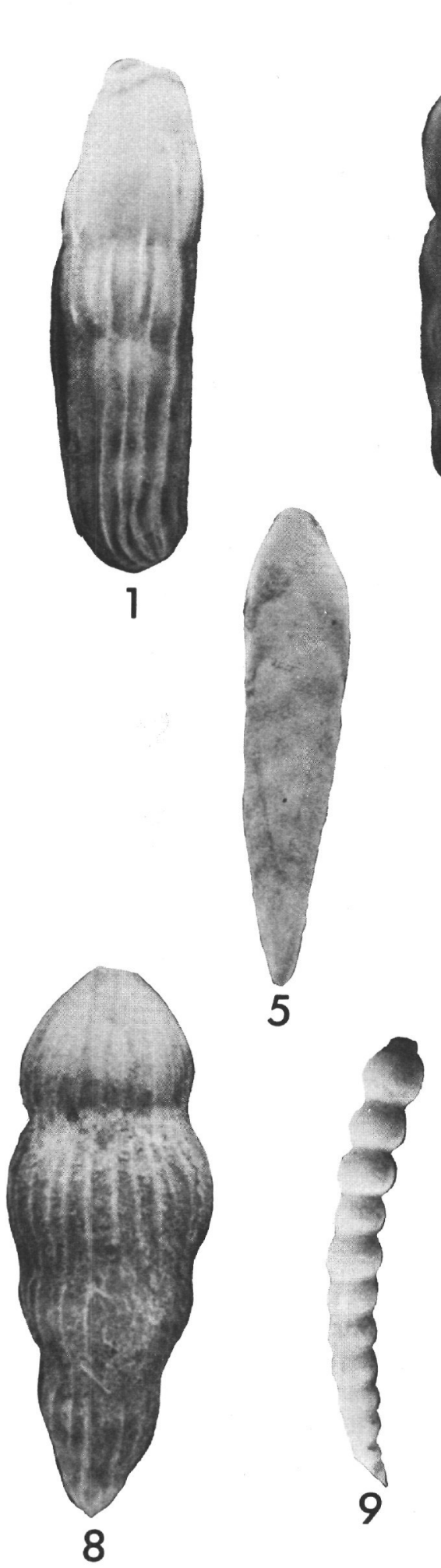

PLATE 5
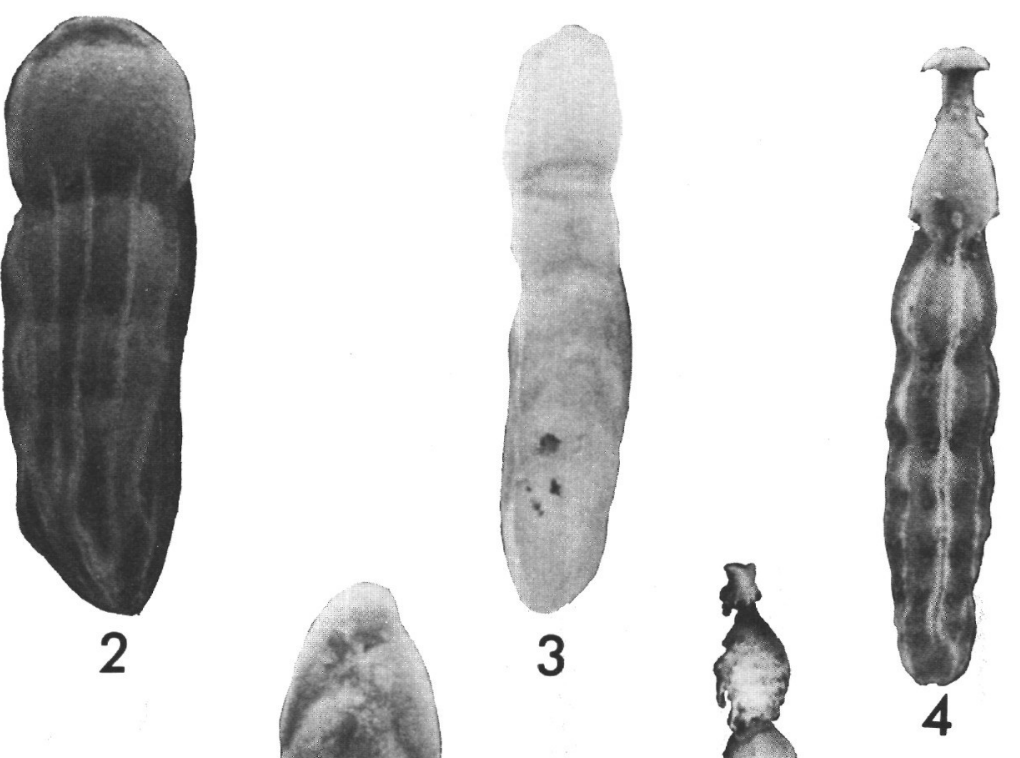


\section{PLATE 6}

Figures 1,2 Favocassidulina sp cf. F. costulata (Cushman). Cassidulina costulata Cushman, 1933, Cushman Lab. Foram. Res. Contr., v. 9, p. 94, pl. 10, fig. 7. Late Oligocene. Both specimens from Samples 167-10-CC. Based on the distinctive surface ornamentation, the species is placed in the genus Favocassidulina (Loeblich and Tappan, 1964). The species is similar to Cassidulina costulata (Cushman), but is more costate and the chambers are narrower and more cresentic shaped. A species figured as C. costulata by Todd (1964) resembles the figured specimen.

1. Maximum diameter of specimen, $0.40 \mathrm{~mm}$.

2. Maximum diameter of specimen, $0.52 \mathrm{~mm}$.

Figure 3 Cassidulina subglobulosa Brady, 1881, Quart. J. Micr. Sci., v. 21, p. 60; Repts. Voy. Challenger v. 9, pl. 54, fig. 17. Recent-Eocene. Maximum diameter of specimen, $0.60 \mathrm{~mm}$, Sample 171-8-CC. This well-known species is common at both sites. Both the typical form of the species and the variety occur in Eocene samples at Sites 167 and 171 .

Figures 4, 5 Favocassidulina favus (Brady). Pulvinulina favus Brady, 1877, Geol. Mag., v. 4, p. 535. Recent-Middle Miocene. Both specimens from Sample 167-1-CC. This species is abundant in Quaternary sediments from Site 167.

4. Masimum diameter of specimen, $0.80 \mathrm{~mm}$.

5. Maximum diameter of specimen, $0.82 \mathrm{~mm}$.

Figure 6 Cassiculina cushmani R. E. and K. C. Stewart, 1930, J. Paleont., v. 4, p. 71, pl. 9, fig. 5. Miocene. Maximum diameter of specimen, $0.44 \mathrm{~mm}$, Sample 167-6-6, 70-72 cm.

Figure 7 Cassidulina angulosa Cushman, 1933, Cushman Lab. Foram. Res. Contr., v. 9, p. 93, pl. 10, fig. 6. Early Miocene-Oligocene. Maximum diameter of specimen, $0.64 \mathrm{~mm}$, Sample 171-3-CC. The species is restricted to early Oligocene samples at Site 167.

Figure 8 Pyrgo depressa (d'Orbigny). Biloculina depressa (d'Orbigny), 1826, Ann. Sci. Nat., v. 7, p. 298, modèle 90. QuaternaryMiocene. Length of specimen, $1.24 \mathrm{~mm}$; width, $1.20 \mathrm{~mm}$, Sample 167-1-CC.

Figure 9 Pyrgo murrhina (Schwager). Biloculina murrhina Schwager, 1866, Nova-Exped. 1857-59, Geol. Theil., v. 2, p. 303, pl. 4, figs. 15ac. Quaternary-Miocene. Length of specimen $0.64 \mathrm{~mm}$; width, $0.56 \mathrm{~mm}$, Sample 167-1-CC. 
PLATE 6
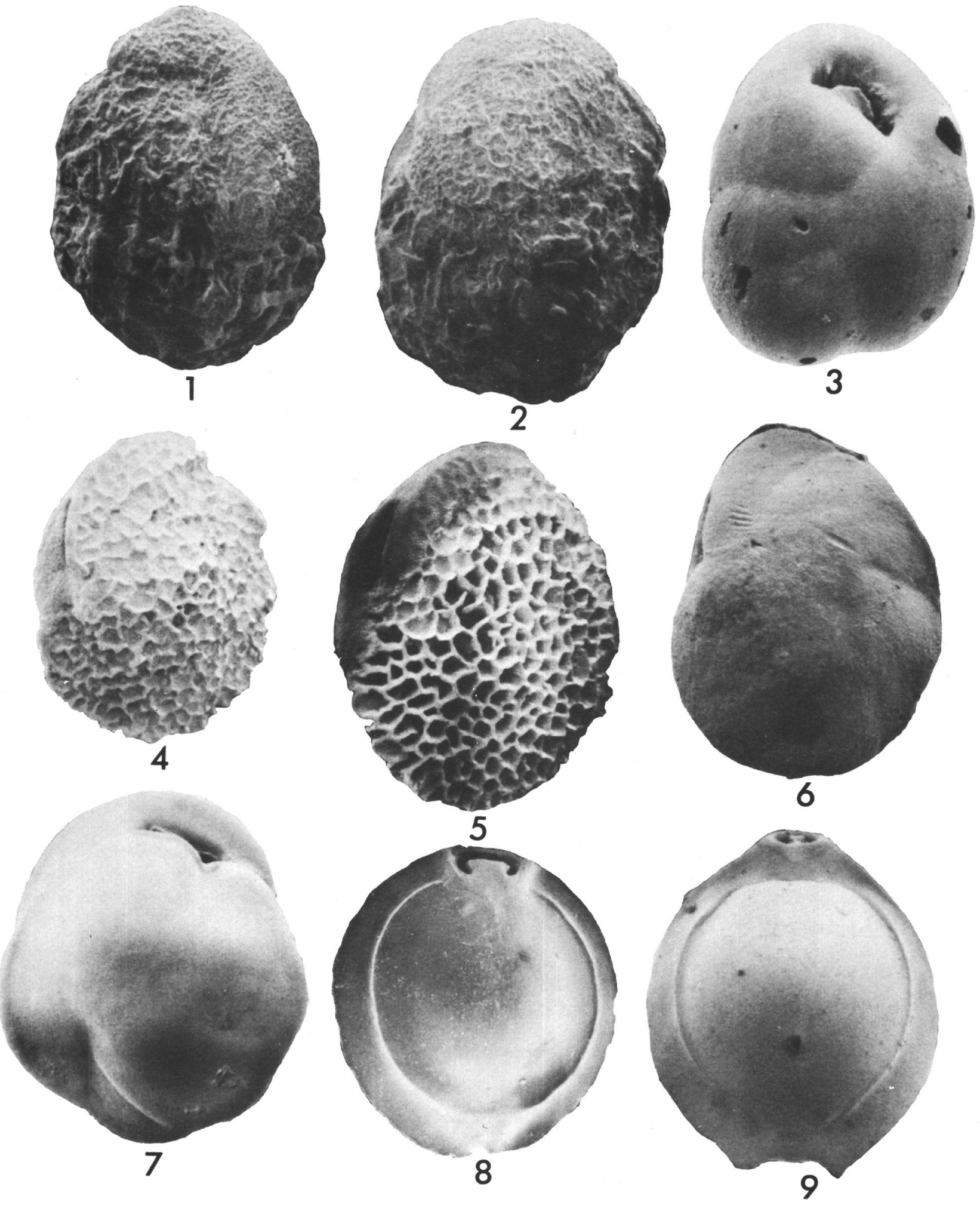


\section{PLATE 7}

Figures 1,2 Bulimina alazanensis Cushman, 1927, J. Paleont., v. 1, p. 161, pl. 25, fig. 4. Early OligoceneEocene. Both specimens from Sample 167-27-CC. This distinctive buliminid is distinguished by its prominent branching, longitudinal ribs. In some specimens a short spine is created by the extension of the ribs from the basal tip. The species is characteristic of the Eocene in the Atlantic and Caribbean.

1. Length of specimen, $0.50 \mathrm{~mm}$; width, $0.32 \mathrm{~mm}$.

2. Length of specimen, $0.48 \mathrm{~mm}$; width, $0.28 \mathrm{~mm}$.

Figure 3 Bulimina trinitatensis Cushman and Jarvis, 1928, Cushman Lab. Foram. Res. Contr., v. 4, p. 102, pl. 14, figs. 12a b. Paleocene-Late Maastrichtian. Length of specimen, $0.48 \mathrm{~mm}$; width, $0.32 \mathrm{~mm}$. Sample 171-9-6, 0-4 cm. The species occurs at Site 171, in Cores 8 and 9. It is widely distributed in late Maastrichtian and Paleocene deposits in the Americas, Atlantic, and Europe.

Figure 4 Bulimina sp. cf. B. macilenta (Cushman and Parker). Bulimina macilenta Cushman and Parker, 1936, Cushman Lab. Foram. Res. Contr., v. 12, p. 42, pl. 7, figs. 7, 8. Eocene. Length of specimen, $0.44 \mathrm{~mm}$; width, $0.36 \mathrm{~mm}$. Sample 171-8-CC. The Pacific species has a distinctive rugose surface which is not mentioned in the original description. Otherwise the species matches the diagnosis of Cushman and Parker's species.

Figure $5 \quad$ Buliminella sp. Early Paleocene(?)-Maastrichtian. Maximum diameter of specimen, $0.36 \mathrm{~mm}$. Sample 171-9-5, 70-72 cm. This distinctive species has spine-like projections on the chambers of the last two whorls. The "spine" is usually absent on the last formed chamber. The species appears to be undescribed. It is tentatively assigned to the genus Buliminella based on the character of the aperture and the arrangement of chambers.

Figures 6,7 Bulimina ovata d'Orbigny, 1846, Foram. Foss. Bass. Tert. Vienne, p. 185, pl. 11, figs. 13 , 14. Miocene-Oligocene. Sample 171-3, CC. Unlike the other buliminids found in the central Pacific, this species has a smooth, nearly poreless surface. The species is common in the Caribbean and Europe.

6. Length of specimen, $0.40 \mathrm{~mm}$; width, $0.36 \mathrm{~mm}$.

7. Detail of aperture of same specimen. Width of view, $0.23 \mathrm{~mm}$.

Figure 8 Quadratobuliminella sp. O. pyramidalis de Klasz. Quadratobuliminella pyramidalis de Klasz, 1953, Neus. Sahrb. Paläont., Mont., v. 10, p. 434-436, test fig. 12. Paleocene-? Late Maastrichtian. Length of specimen, $0.32 \mathrm{~mm}$. This species was originally described from Trinidad and appears to be restricted to Paleocene deep-water deposits. It occurs at Site 171, Core 9. The species is similar to Buliminella beaumonti (Cushman and Jarvis, 1946) from the Lizard Springs Formation of Trinidad, but it differs in lacking a lobular area at the base of the later chambers, and the surface is not smooth.

Figures 9-12 Bulimina jarvisi Cushman and Parker, 1936, Cushman Lab. Foram. Res. Contr., v. 12, p. 39, pl. 7, fig. 1. Early Miocene-Eocene. Both specimens from Sample 171-5, CC. In the Caribbean and at Site 171 the species extends into the Eocene, but it is absent from Eocene sediments at Site 167, except for Core 27. It seems likely the species is not preserved in the hard chalks of the Eocene cores at Site 167.

9. Detail of same specimen illustrating the distinctive pitted surface texture of the species; width of view, $0.10 \mathrm{~mm}$.

10. Length of specimen, $0.76 \mathrm{~mm}$; width, $0.32 \mathrm{~mm}$.

12. Detail of same specimen; width of view, $0.10 \mathrm{~mm}$. 


\section{PLATE 7}
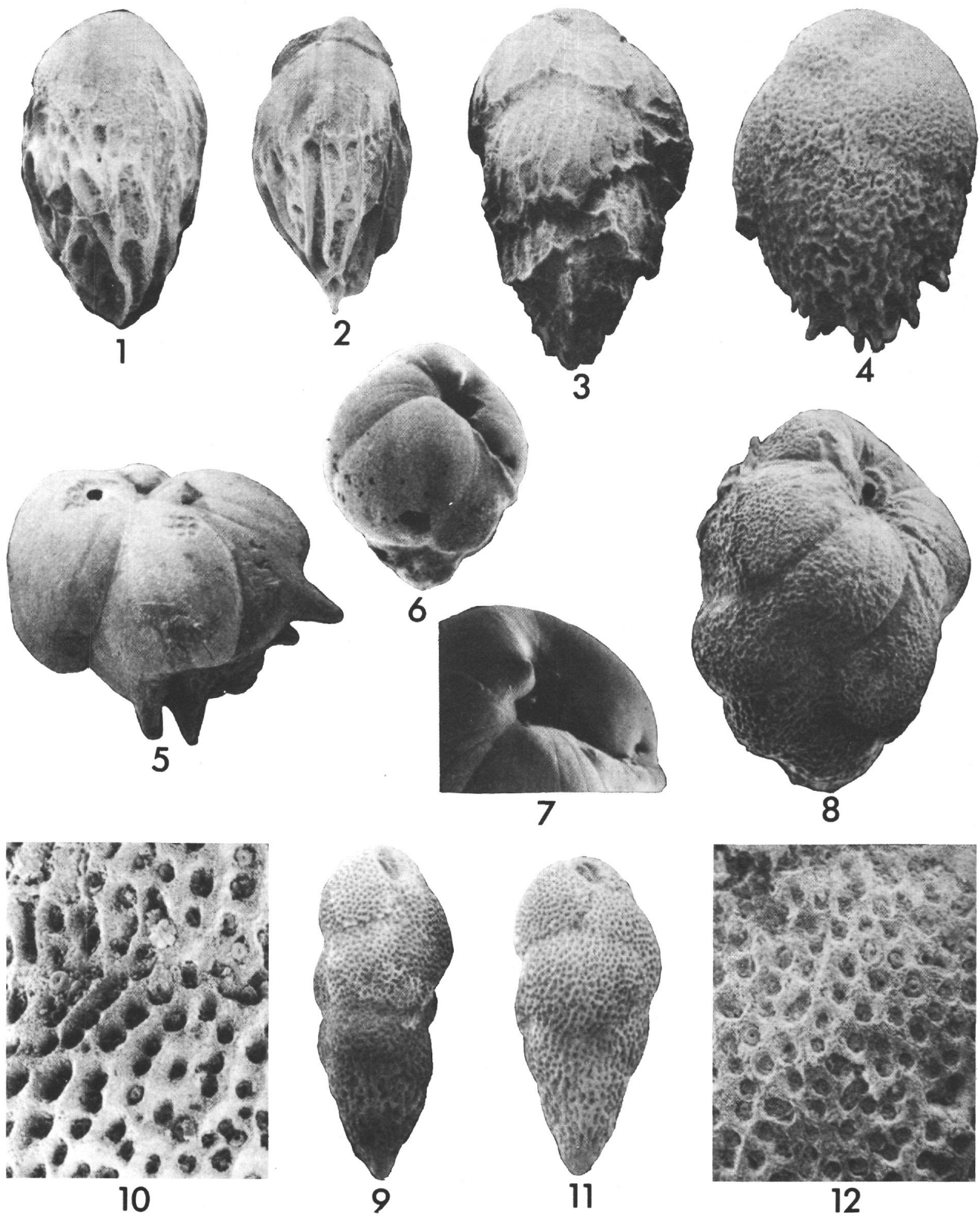


\section{PLATE 8}

Figures 1,2 Pullenia bulloides (D’Orbigny). Nonionina bulloides d'Orbigny, 1846, Foram. Foss. Bass. Tert. Vienne. p. 107, pl. 5, figs. 9, 10. Quaternary-Eocene. Sample 167-1-CC.

1. Side view. Maximum diameter of specimen, 0.32 $\mathrm{mm}$.

2. Aperture view. Maximum diameter of specimen, $0.35 \mathrm{~mm}$.

Figure 3

Figures 4-6, 9

Figure 7

Figure 8

Figure 10

Figure 11
Uvigerina rustica Cushman and Edwards, 1938, Cushman Lab. Foram. Res. Contr., v. 14, p. 83, pl. 14, fig. 6. Oligocene-Eocene. Length of specimen, $0.72 \mathrm{~mm}$; width, $0.24 \mathrm{~mm}$, Sample 171-6-1, 0-2 cm.

Uvigerina peregrina (Cushman), 1923, U. S. Nat. Mus. Bull. 104, p. 166, pl. 42, figs. 7-10. QuaternaryMiocene, All specimens from Sample 167-1-CC. This common deep-sea species is abundant in Quaternary sediments at Site 167; it is not present at Site 171.

4. Length of specimen, $0.78 \mathrm{~mm}$; width, $0.32 \mathrm{~mm}$.

5. Length of specimen, $0.92 \mathrm{~mm}$; width, $0.38 \mathrm{~mm}$.

6. Length of specimen, $0.79 \mathrm{~mm}$; width, $0.32 \mathrm{~mm}$.

9. Length of specimen, $0.41 \mathrm{~mm}$; width, $0.27 \mathrm{~mm}$.

Uvigerina vadescens (Cushman). Uvigerina proboscidea Schwager var. vadescens Cushman, 1933, Cushman Lab. Foram. Res. Contr., v. 9, p. 85, pl. 8 , figs. 14, 15. Quaternary-Pliocene. Length of specimen, $0.80 \mathrm{~mm}$; width, $0.24 \mathrm{~mm}$, Sample 167-1-CC. The species differs from $U$. proboscidea in the more widely spaced biserial chambers and possession of a basal spine.

Uvigerina proboscidea Schwager, 1866, NovaraExped. Geol. Theil., v. 2, p. 250, pl. 7, fig. 96. Quaternary-Pliocene. Length of specimen, $1.04 \mathrm{~mm}$; width, $0.40 \mathrm{~mm}$, Sample 167-1-CC. This distinctive species is common in Quaternary deep-sea sediments.

Uvigerina gallowayi Cushman, 1929, Cushman Lab. Foram. Res. Contr., v. 5, p. 95, pl. 13, figs. 33, 34. Oligocene. Length of specimen, $0.56 \mathrm{~mm}$; width 0.40 mm, Sample 171-6-1, 0-2 cm. Rare occurrences of this species are found in Oligocene sediments at Site 171. The species is similar to $U$. mexicana Nuttall, but it has more plate-like ribs, and the sutures are not depressed.

Uvigerina spinulosa (Hadley). Uvigerina Canariensis d'Orbigny var. spinulosa Hadley, 1934, Am. Paleont. Bull., v. 20, p. 18, pl. 2, fig. 17. Miocene-Late Oligocene. Length of specimen, $0.56 \mathrm{~mm}$; width, 0.28 mm, Sample 171-3, CC. The species resembles $U$. nitidula Schwager, but the original description gives no mention of peripheral spines or spines at the base of the shell. 

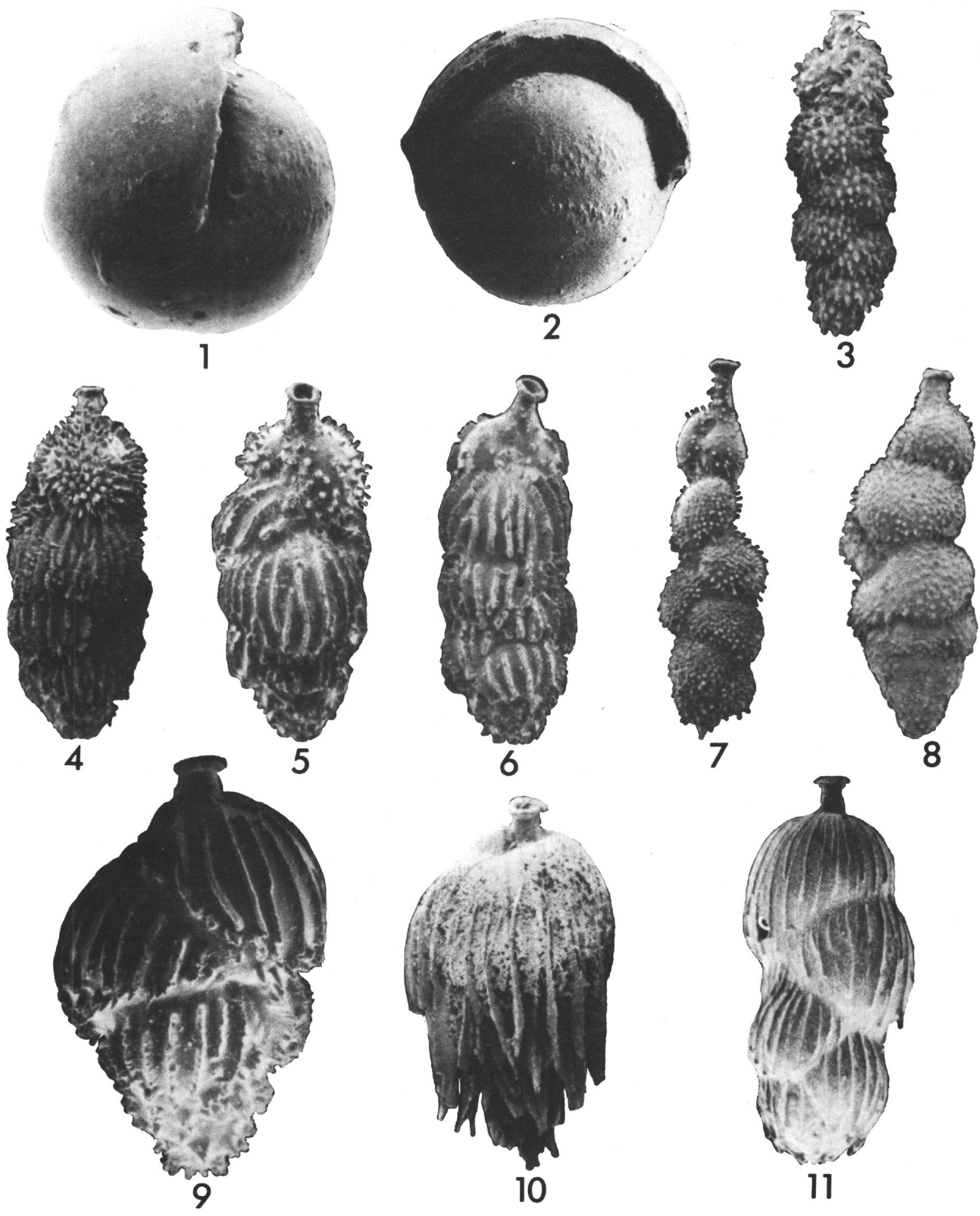


\section{PLATE 9}

Figures 1,2 Melonis affinis (Reuss). Nonionina affinis Reuss, 1851, Deutsch. Geol. Gesell., Z., v. 3, p. 49, pl. 5, fig. 32. Quaternary-Pliocene (? Miocene). Maximum diameter of specimen, $0.76 \mathrm{~mm}$, Sample 167-1, CC.

Figure 3 Melonis guadalupe Parker, 1964, J. Paleont., v. 38, p. 633, pl. 100, figs. 13, 14. Quaternary-Miocene. Side view. Maximum diameter of specimen, $0.48 \mathrm{~mm}$, Sample 167-1-CC. The species differs from M. affinis by its smaller pores, smaller size, and fewer chambers per whorl.

Figures 4, $5 \quad$ Pullenia quinqueloba (Reuss). Nonionina quinqueloba Reuss, 1857, Z. Deutsch. Geol. Gesell., v. 3, p. 47, pl. 5, fig. 31. Quaternary-Oligocene. Maximum diameter of specimen, $0.48 \mathrm{~mm}$, Sample 167-1-CC.

Figures 6,7 Pullenia subcarinata (d'Orbigny). Nonionina subcarinata d'Orbigny, 1839, Voy. l'Am. Meridionale, Leurault, v. 5, p. 28, pl. 5, figs. 23, 24. QuaternaryPliocene. Maximum diameter of specimen, $0.48 \mathrm{~mm}$, Sample 167-1-CC.

Figures 8,9 Melonis pompilioides (Fichtel and Moll). Nautilus pompilioides Fichtel and Moll, 1798, Test. Micr., Wien, p. 1-124, pl. 2, figs. a-c. Quaternary-Pliocene. Maximum diameter of specimen, $0.40 \mathrm{~mm}$, Sample 167-1-CC. This well-known deep-sea species is restricted to Site 167 . 


\section{PLATE 9}
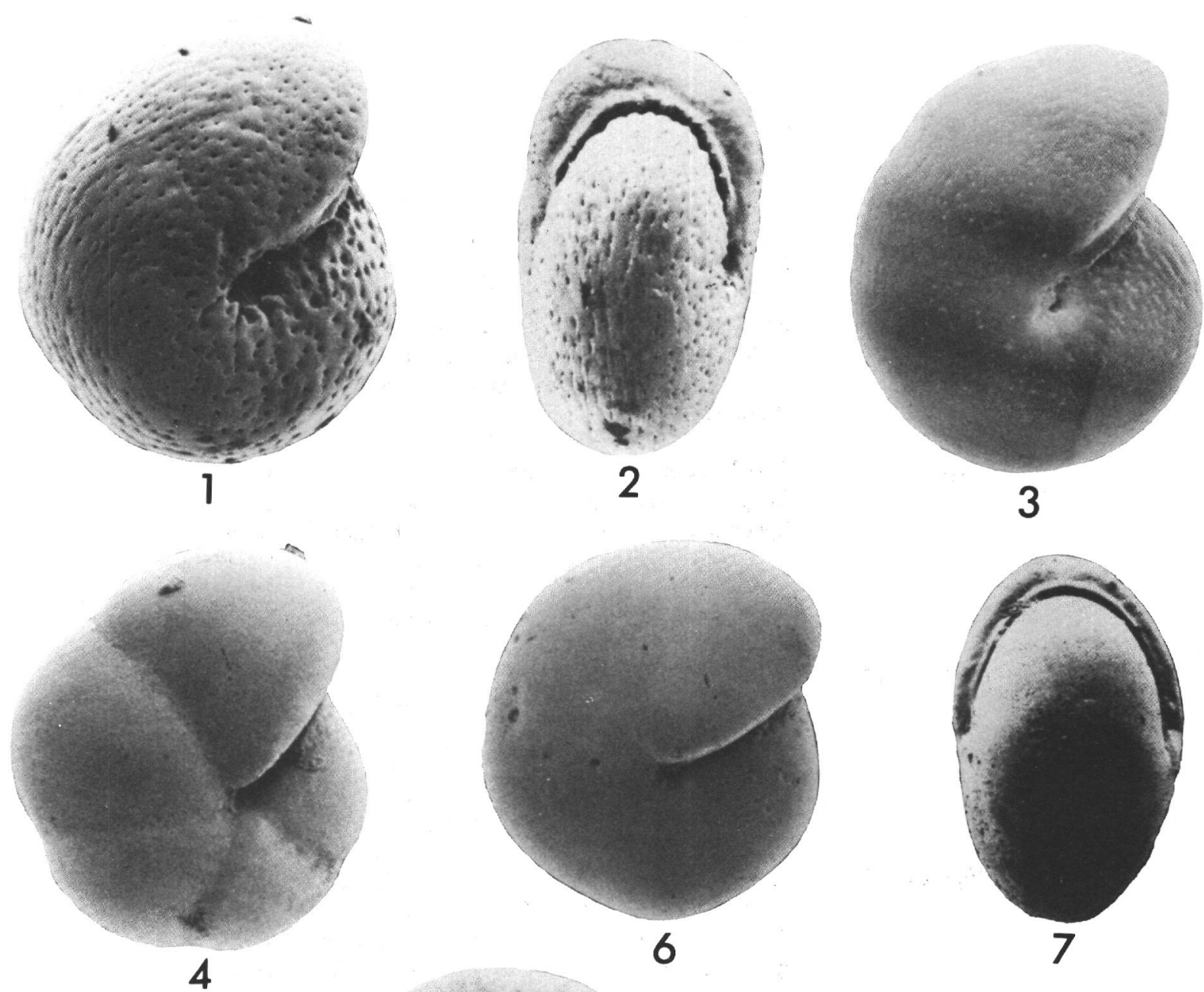

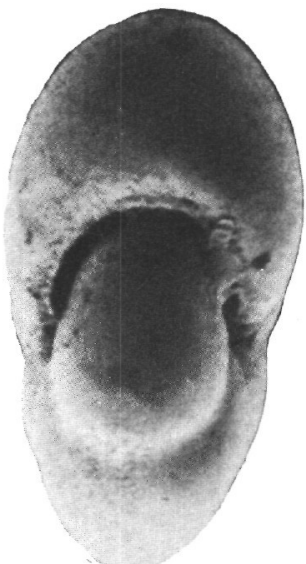

5
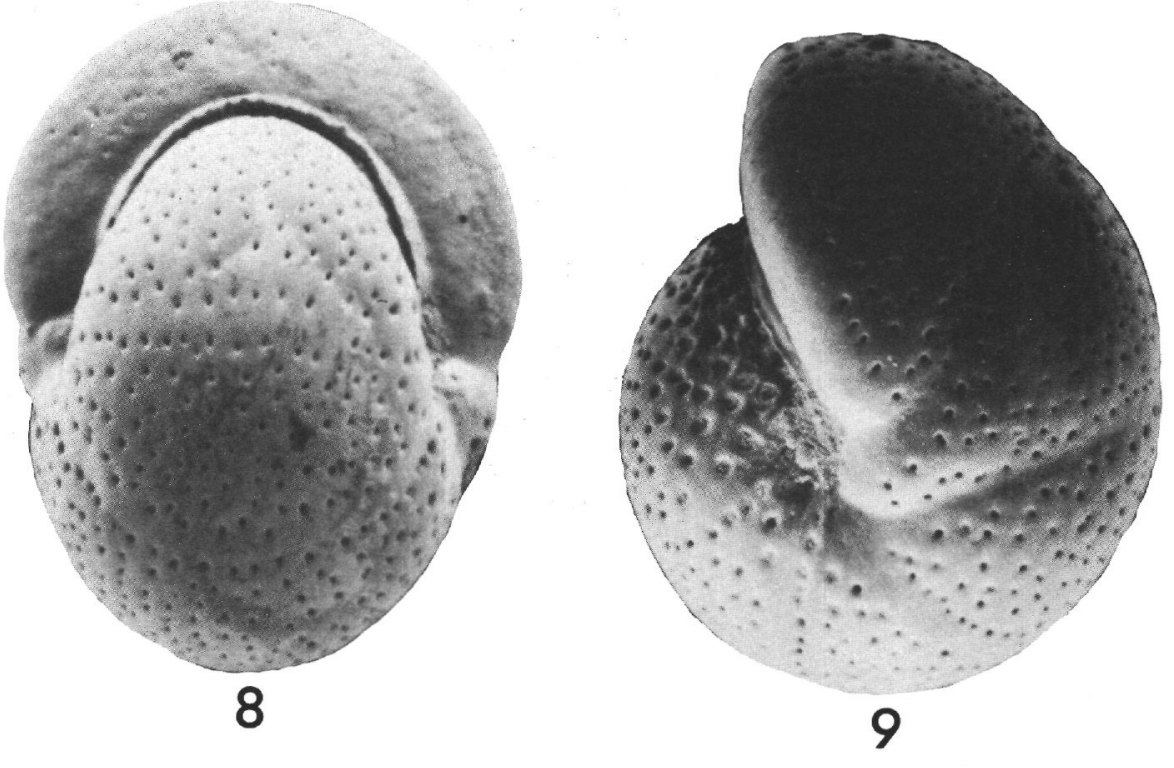
PLATE 10

Figures 1,2 Ehrenbergina hytrix Brady, 1884, Repts. Voy. Challenger, v. 9, p. 434, pl. 55, figs. 8-11. Miocene. Length of specimen, $0.32 \mathrm{~mm}$; width, $0.20 \mathrm{~mm}$, Sample $167-5-5,70-72 \mathrm{~cm}$. The species occurs only in early and middle Miocene cores at Site 167. It has been reported from the experimental Mohole cores (Parker, 1964).

Figure 3 Neoflabellina sp. Paleocene?-Late Maastrichtian. Length of specimen, $1.26 \mathrm{~mm}$, Sample 167-38-CC. Specimens of this species, mostly broken, occur in Cores 38 and 39 at Site 167. A similar species is present in late Maastrichtian samples at Site 171, but there are too few specimens for adequate comparison.

Figures 4,5 Ehrenbergina gibbera Galloway and Heminway. Ehrenbergina serrata Reuss var. gibbera Galloway and Heminway, 1941, N. Y. Acad. Sci., Sci. Surv. Puerto Rico and Virgin Islands, v. 3, p. 427, pl. 32, figs. 5a-d. Miocene. Length of specimen, $0.33 \mathrm{~mm}$; width (excluding spines), $0.30 \mathrm{~mm}$, Sample 171-2-CC.

Figures 6,7 Aragonia velascoensis (Cushman). Textularia velascoensis Cushman, 1925, Contr. Cushman Lab. Foram. Res., v. 1, p. 18, pl. 3, fig. 1. Paleocene. Both specimens from Sample 171-9-6, 0-4 cm. The sutures are slightly elevated and the chamber surface is covered with a reticulated or branching pattern. These features make the species easily distinguished from other Aragonia. The species is common in Cores 38, 39, and 40 at Site 167 and in Core 9 at Site 171.

6. Length of specimen, $0.40 \mathrm{~mm}$; width, $0.24 \mathrm{~mm}$.

7. Length of specimen, $0.44 \mathrm{~mm}$; width, $0.30 \mathrm{~mm}$.

Figure 8 Laticarinina pauperata (Parker and Jones). Pulvinulina repanda menardii pauperata Parker and Jones, 1865, Phil. Trans., v. 155, p. 395, pl. 16, figs. 50, 51. Quaternary-Miocene. Maximum diameter of specimen, $1.34 \mathrm{~mm}$, Sample 167-1-CC. 
PLATE 10
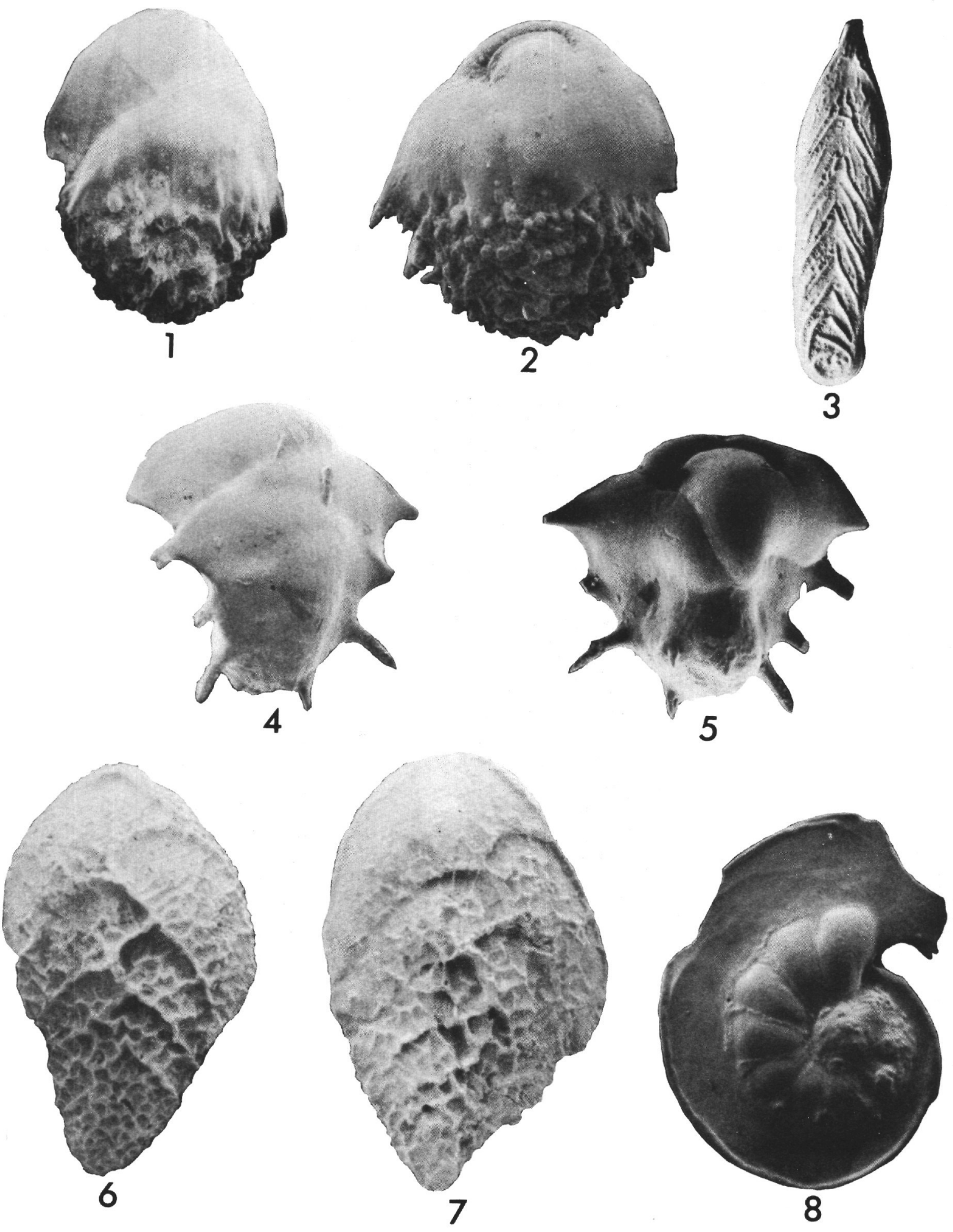


\section{PLATE 11}

Figures 1-3 Osangularia interrupta (Cushman). (See pl. 25, figs. 19, 20.) Pulvinulinella interrupta Cushman, 1927, Cushman Lab. Foram. Res. Contr., v. 3, p. 115, pl. 22, figs. 10a-c. Early Miocene-Late Eocene. Maximum diameter of specimen, $0.48 \mathrm{~mm}$, Sample 171-5-CC. The figured species is slightly more biconvex than the holotype described by Cushman. It is readily separated from Osangularia mexicana by the fewer number of chambers, smaller size, and the frilled keel. Cushman reported the species from the Eocene of Mexico. In the Pacific it ranges from the Lower Miocene to Oligocene.

Figures 4-6 Osangularia mexicana (Cole) (see pl. 25, figs. 17, 18.). Pulvinulinella culter (Parker and Jones) var. mexicana Cole, 1927, Am. Paleont. Bull., v. 14, pl. 1, figs. 15, 16. Early Oligocene-Eocene. Maximum diameter 0.88 $\mathrm{mm}$, Sample 171-8-CC. The species is large, biconvex, with 12-15 chambers in the final whorl and a wide keel, especially in the early part of the last whorl. The edge of the keel is smooth, giving the species a circular outline. Prior to photographing the spiral view (Figure 6), a portion of the keel on the side opposite the apertural face was broken.

Figures 7-9 Anomalinoides sp. Miocene-Oligocene. Maximum diameter of specimen, $0.68 \mathrm{~mm}$, Sample 167-7-CC. 
PLATE 11
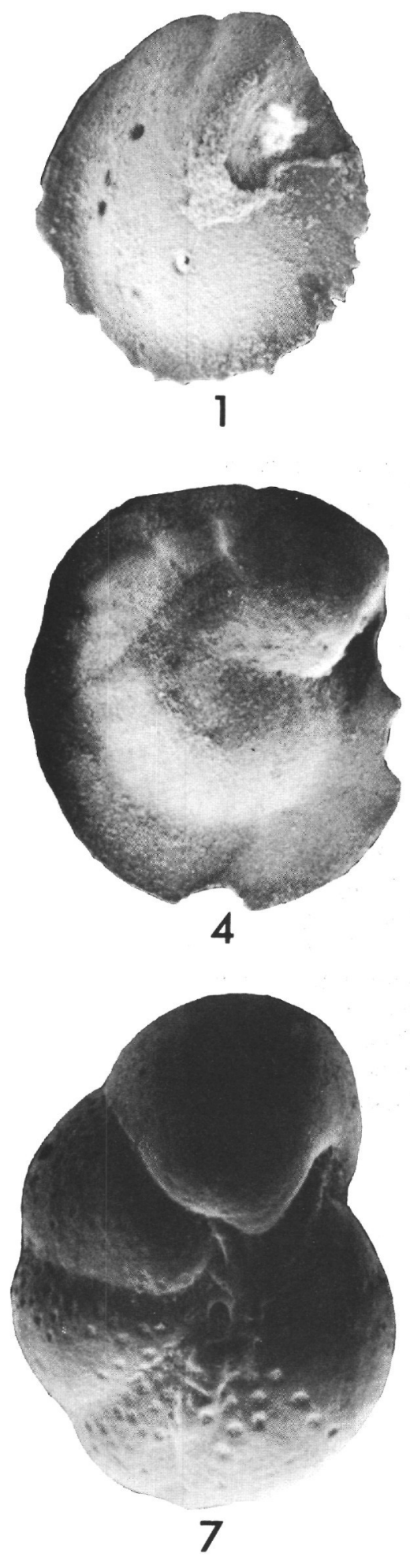
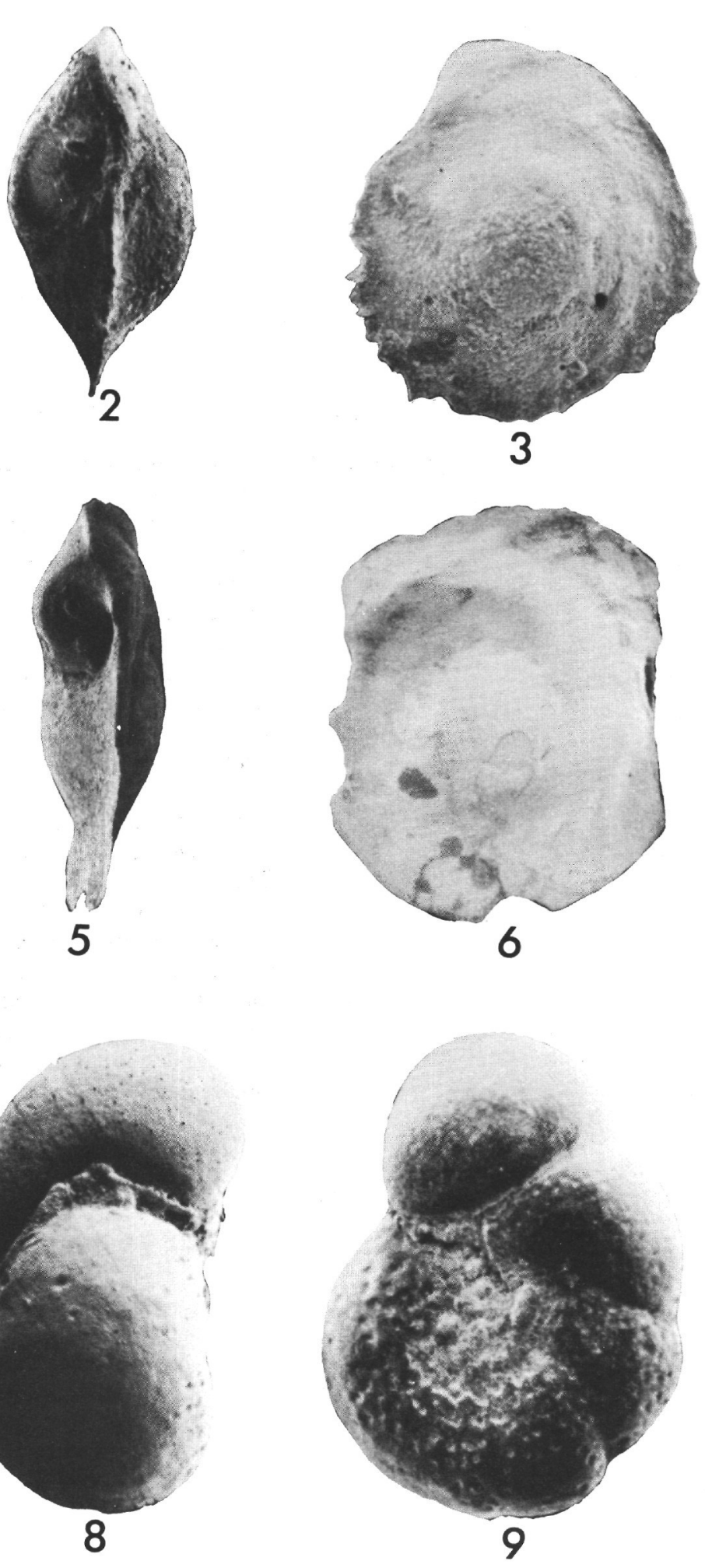
PLATE 12

Figures 1-3 Boldia cushmani (Nuttall). Cibicides cushmani Nuttall, 1930, J. Paleont., v. 4, p. 291, pl. 25, figs. 3, 5 , 6. Eocene. Maximum diameter of specimen, 0.40 $\mathrm{mm}$, Sample 171-8-CC. The species is placed in the genus Boldia based on the presence of raised sutures, truncate periphery, and supplementary apertures on the umbilical side. Rare occurrences of this species are found at Site 171, DSDP 44 and early Eocene sediments on the Shatsky Rise (DSDP Site 47). The species is characteristic of the Eocene in the Caribbean region.

Figures 4-9 Gyroidina zealandica Finlay (see pl. 24, figs. 5, 6). Gyroidina zealandica Finaly, 1939, Roy. Soc. New Zeal. Trans. Proc., v. 67, p. 323, pl. 28, figs. 138-140. Quaternary-Early Oligocene. The tangentially arranged sutures on the spiral side and the convex shell separates this species from the other gyroidinids found in the central Pacific. The species is common in Neogene and Oligocene sediments. Sample 171-3-CC. 4-6. Maximum diameter of specimen, $0.56 \mathrm{~mm}$. 7-9. Maximum diameter of specimen, $0.43 \mathrm{~mm}$. 
PLATE 12
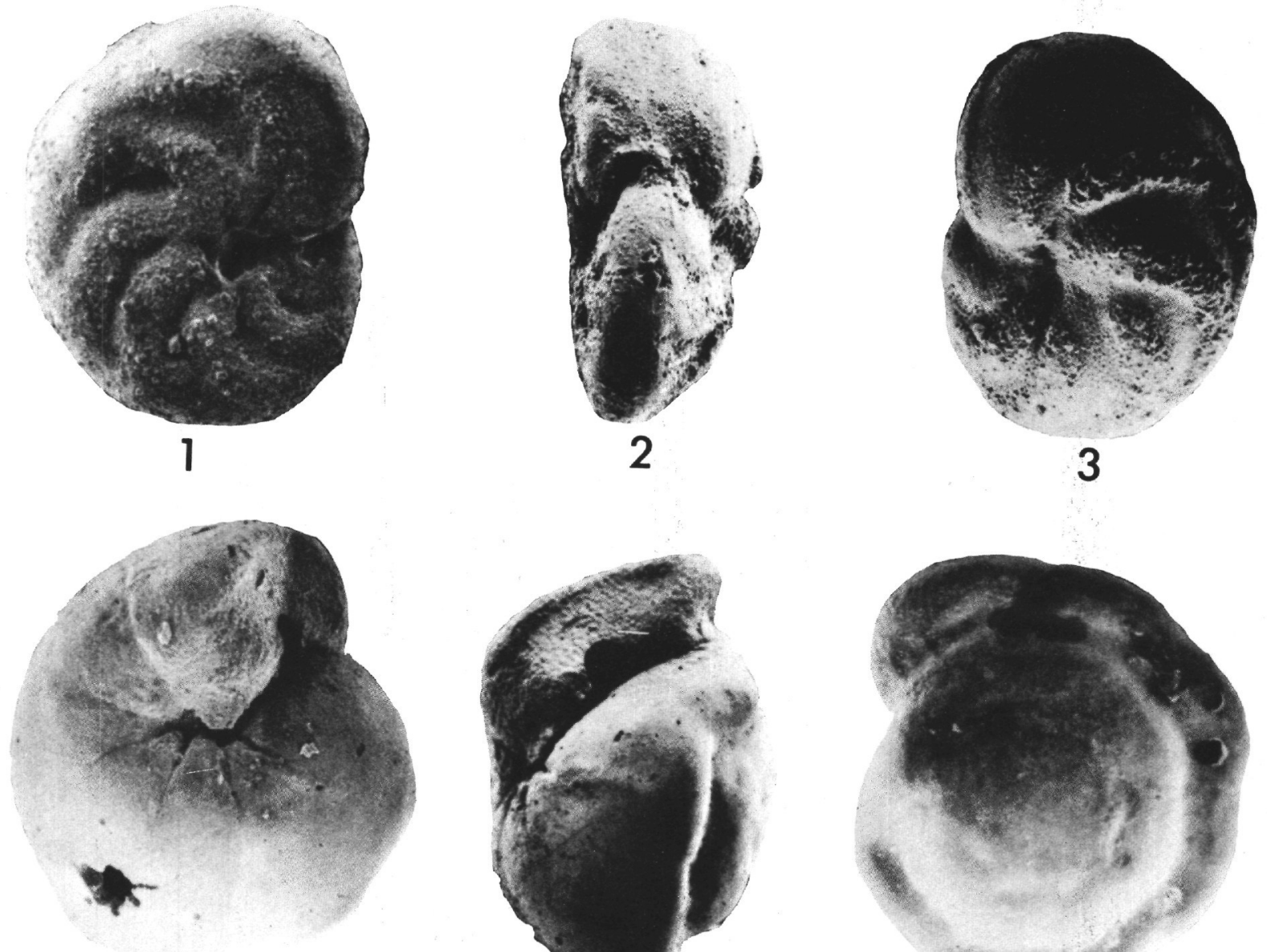

4
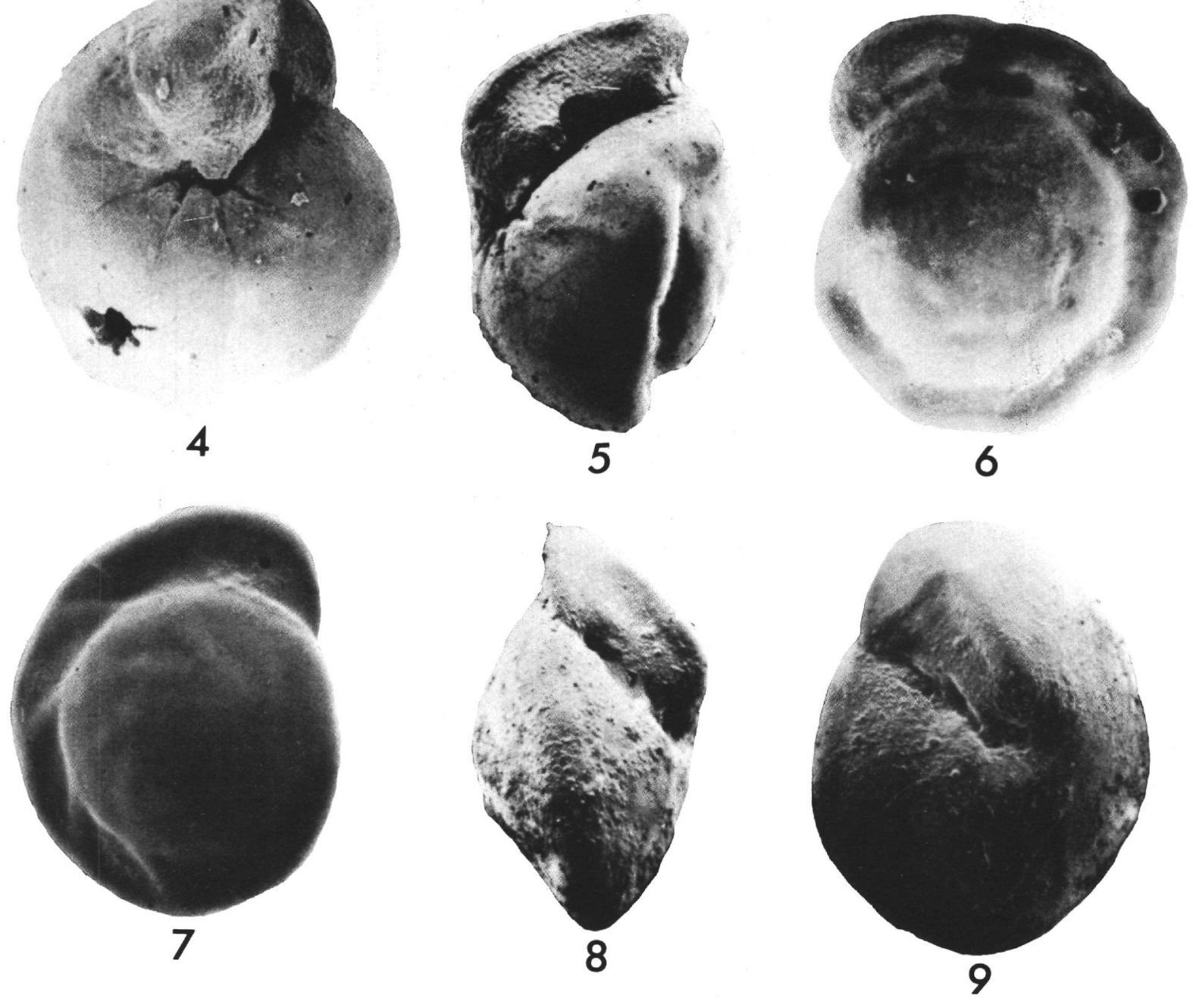


\section{PLATE 13}

Figures 1-6

Figures 7-9
Oridorsalis umbonatus (Reuss). Rotalina umbonata Reuss, 1851, Z. Deutsch. Geol. Gesell., v. 3, p. 75, pl. 5, fig. 35. Quaternary-Eocene. Both specimens from Sample 167-1-CC. The species is very common in samples from the central Pacific. The typical form occurs throughout the Neogene. In early Oligocene and Eocene samples the variety $O$. umbonatus ecuadorensis (Galloway and Morrey) occurs at Site 167 and in Eocene samples at Site 171.

1-3. Adult form. Maximum diameter of specimen, $0.72 \mathrm{~mm}$.

4-6. Juvenile form. Maximum diameter of specimen, $0.48 \mathrm{~mm}$.

Planulina renzi Cushman and Stainforth, 1945, Cushman Lab. Foram. Res. Spec. Publ., v. 14, p. 72, pl. 15, fig. 1. Oligocene. This distinctive species was originally described from the Cipero Marl of Trinidad and seems to be confined to the Oligocene.

7, 8. Maximum diameter of specimen, $0.80 \mathrm{~mm}$, Sample 171-5-CC.

9. Detail of chamber surface showing pore pattern, width of view, $0.08 \mathrm{~mm}$. 


\section{PLATE 13}
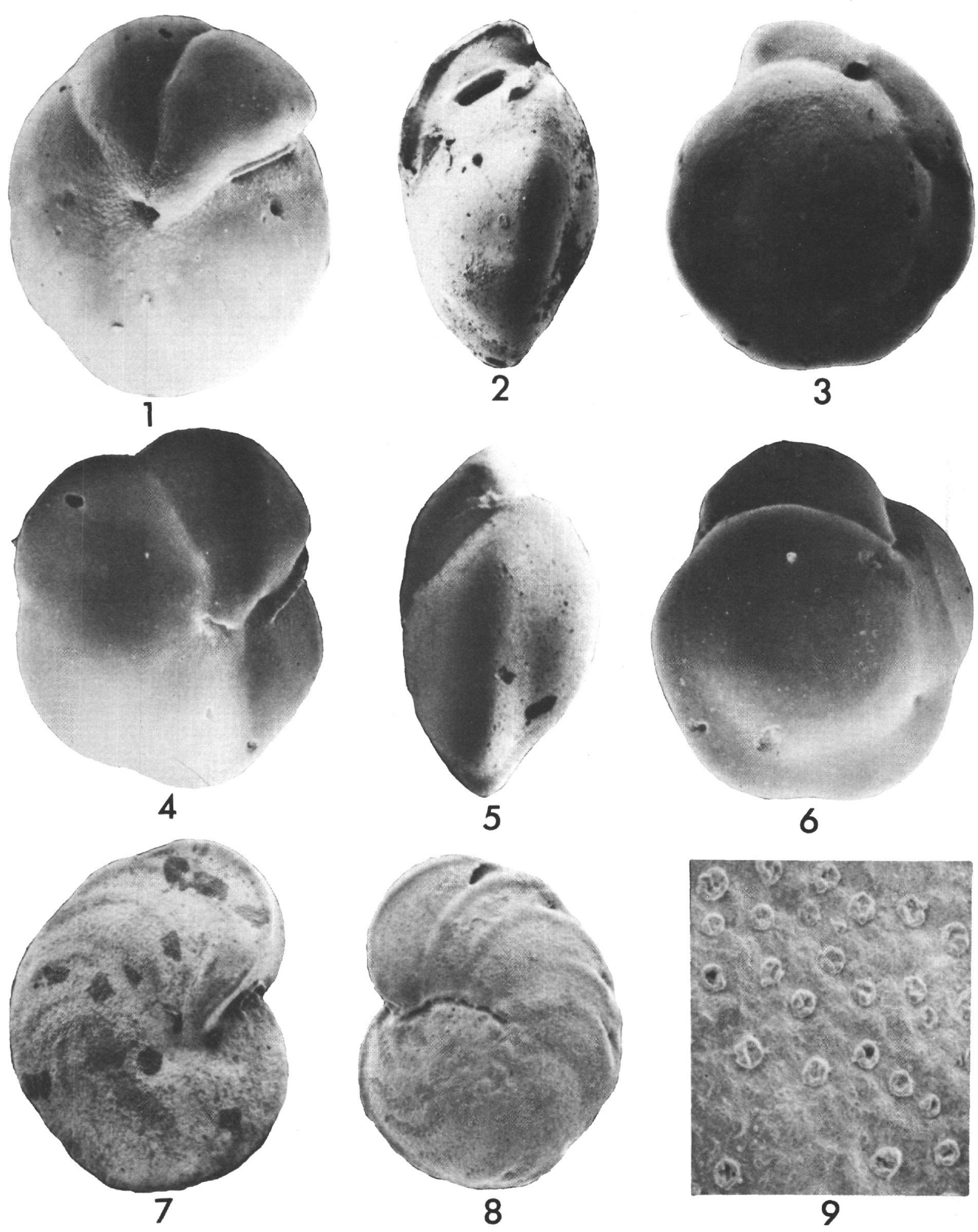


\section{PLATE 14}

Figures 1,2 Anomalinoides semicribrata (Bechmann). Anomalina pompilioides Galloway and Heminway var. semicribrata Beckmann, 1953, Ec. Geol. Helv., v. 10, p. $400-401$, pl. 27 , fig. 3 , text figs. 24,25 . Middle Miocene-Middle Eocene. Maximum diameter of specimen, $0.73 \mathrm{~mm}$, Sample 167-9-2, $70-72 \mathrm{~cm}$. The shell is nearly planispiral, being more completely involuted on the umbilical side than on the spiral side, with 5-6 chambers in the final whorl. It differs from $A$. pompilioides Galloway and Heminway in having pores only on the umbilical side of the test and the less lobate periphery. Beckmann (1953) considered the species as a variety of $A$. pompilioides, but the difference in development of the pores readily sets it apart.

Figures 3-5 Bolidia sp. Paleocene or Late Maastrichtian, Maximum diameter of specimen, $0.48 \mathrm{~mm}$, Sample 171-9-6, 0-4 cm. The species is similar to Cibicorbis herrecki Hadley (= Cibicides kugleri Cushman and Renz) from the Oligocene of Venezuela and Cuba, but differs in its more inflated spiral chambers and truncated margin with weak keels. Two specimens of this distinctive species were found in the mixed Cretaceous-Eocene samples at Site 171. The genus is reportedly restricted to the Paleocene to Middle Eocene (Loeblich and Tappan, 1964).

Figures 6-8 Gavelinella sp. Eocene. Maximum diameter of specimen, $0.55 \mathrm{~mm}$, Sample 171-8-5, 70-72 cm. A few specimens occur in Eocene samples at Site 171. Pores are restricted to the umbilical side of the shell and extend from the margin to the inner edge of the umbilicus, but do not include the umbilical flaps. The shell is nearly planispiral with 10-12 chambers in the final whorl. Sutures are depressed, slightly curves, and create a slightly lobulate outline. 
PLATE 14
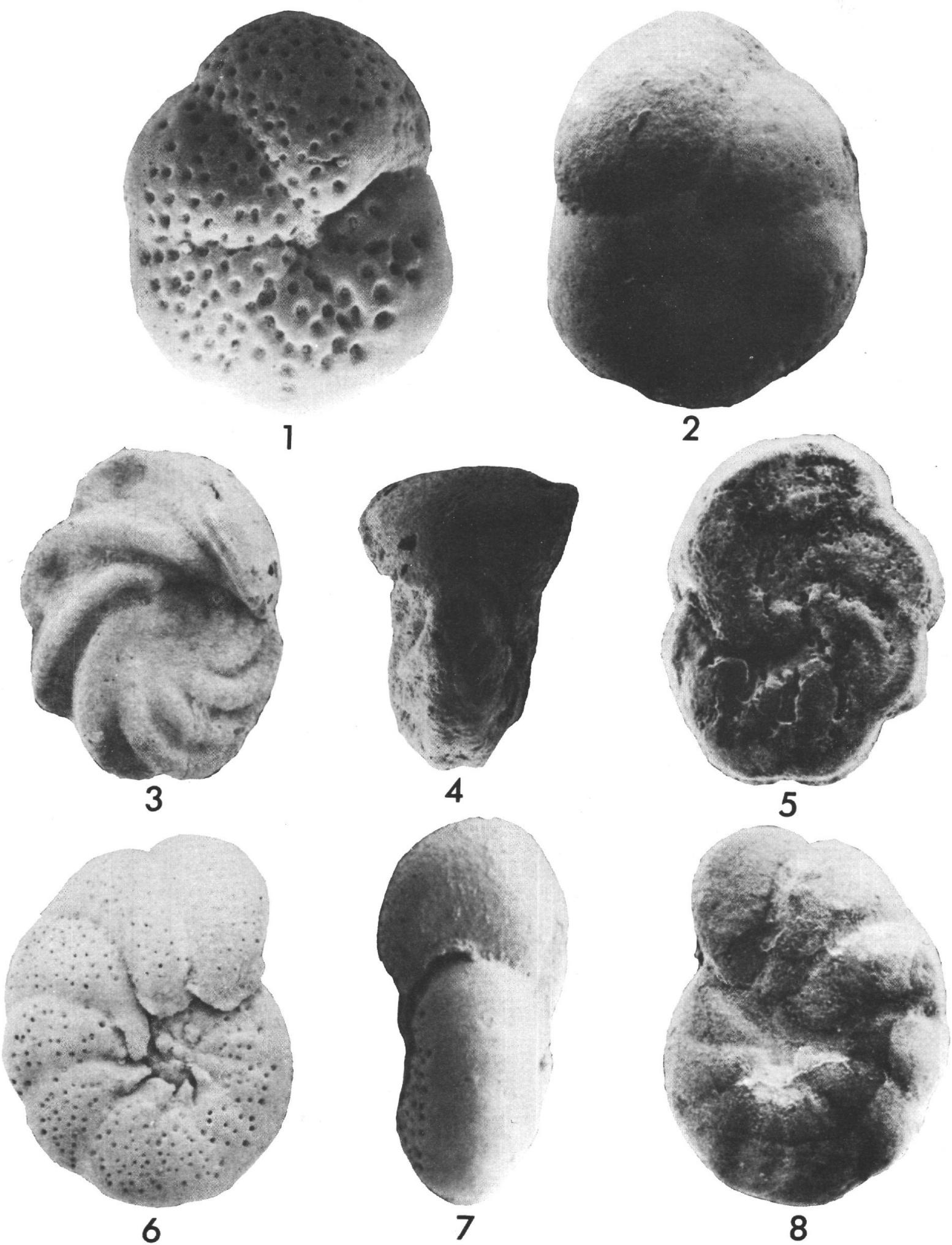


\section{PLATE 15}

Figures 1-6 Cibicidoides grimsdalei (Nuttall). Cibicides grimsdalei Nuttall, 1930, J. Paleont., v. 4, p. 291, pl. 25, figs. 7 , 8, 11. Early Miocene-Eocene. Both specimens from Sample 167-10-CC. This species is characteristic of the Oligocene and Eocene in the Atlantic (Berggren, 1972) and Caribbean region. The shell is planoconvex with the spiral side flat or very slightly convex. There are 8-10 chambers in the final whorl. The inner area of the spiral side is covered with large pits and pore depressions. The presence of these pits readily distinguishes the species from the similar species $C$. perlucidus (Nuttall).

Figures 7-9 Cibicidoides perlucidus (Nuttall). Cibicides perlucidus Nuttall, 1932, J. Paleont., v. 6, p. 33, pl. 8, figs. 10-12. Oligocene-Eocene. Maximum diameter of specimen, $0.84 \mathrm{~mm}$, Sample 167-14-CC. The species differs from C. grimsdalei (Nuttall), with which it is commonly associated, by the smaller spiral pores, more numerous umbilical pores, the restriction of the aperture towards the spiral face, and the more inflated umbilical chambers. The species is restricted to the Oligocene to Eocene in the Caribbean, Atlantic, and Mediterranean. 
Plate 15
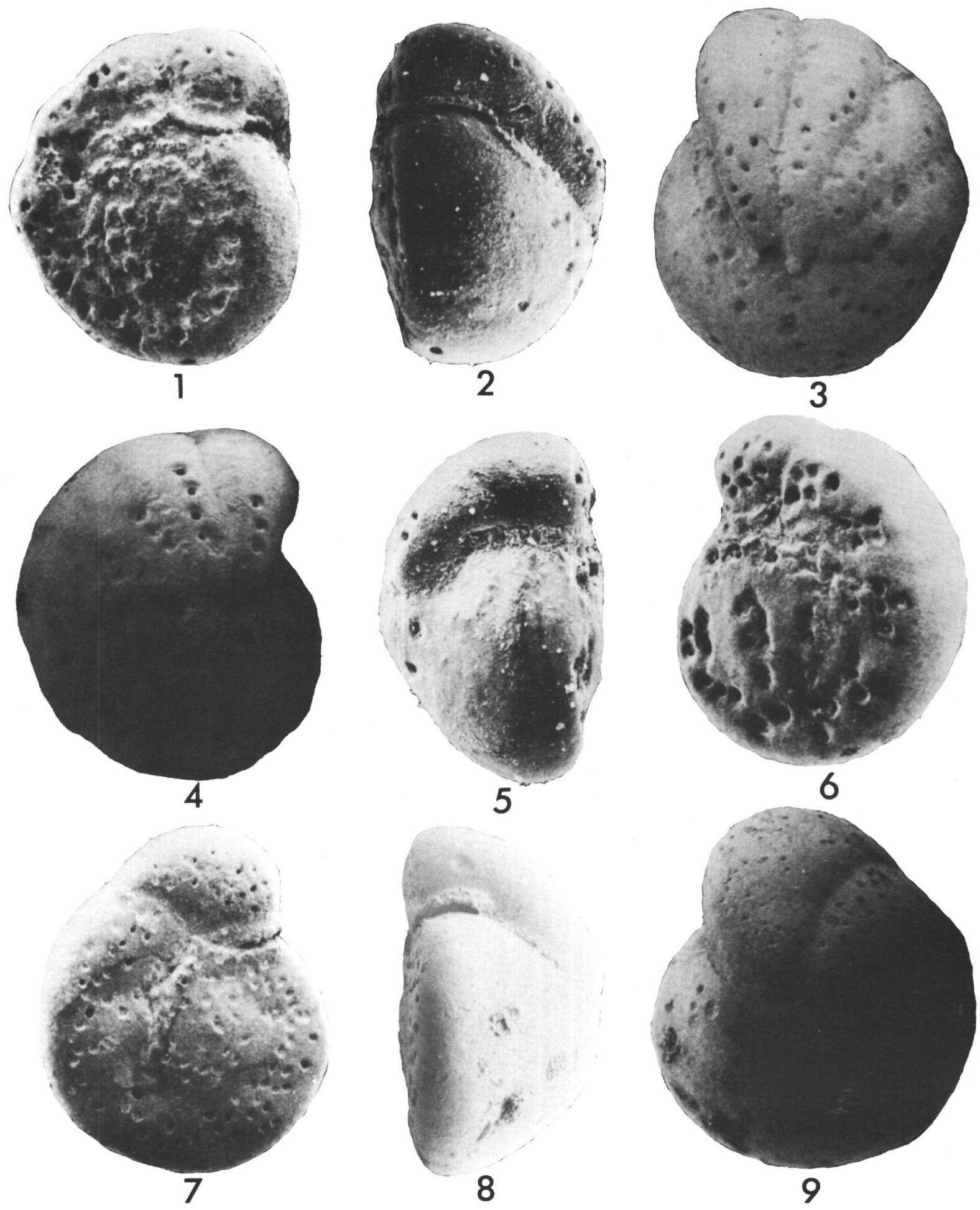
PLATE 16

Figures 1-6 Cibicidoides haitensis (Coryell and Rivers). Cibicides robertsonianus (H. B. Brady) var. haitensis Coryell and Rivers, 1940, J. Paleont., v. 14, p. 335, pl. 44, figs. 4-6, Oligocene. Both specimens from Sample 171-5-CC.

1-3. Juvenile form. Maximum diameter of specimen, $1.04 \mathrm{~mm}$

4-6. Adult form. Maximum diameter of specimen, $1.44 \mathrm{~mm}$.

Figures 7-9 Cibicidoides centralis (Bermudez). Cibicides centralis Bermudez, 1949, Cushman Lab. Foram. Res. Spec. Publ., v. 25 , p. 295 , pl. 24 , figs. 37-39. Eocene. Maximum diameter of specimen, $0.90 \mathrm{~mm}$, Sample $171-8-5,70-72 \mathrm{~cm}$. The species is restricted to Site 171. 
PLATE 16
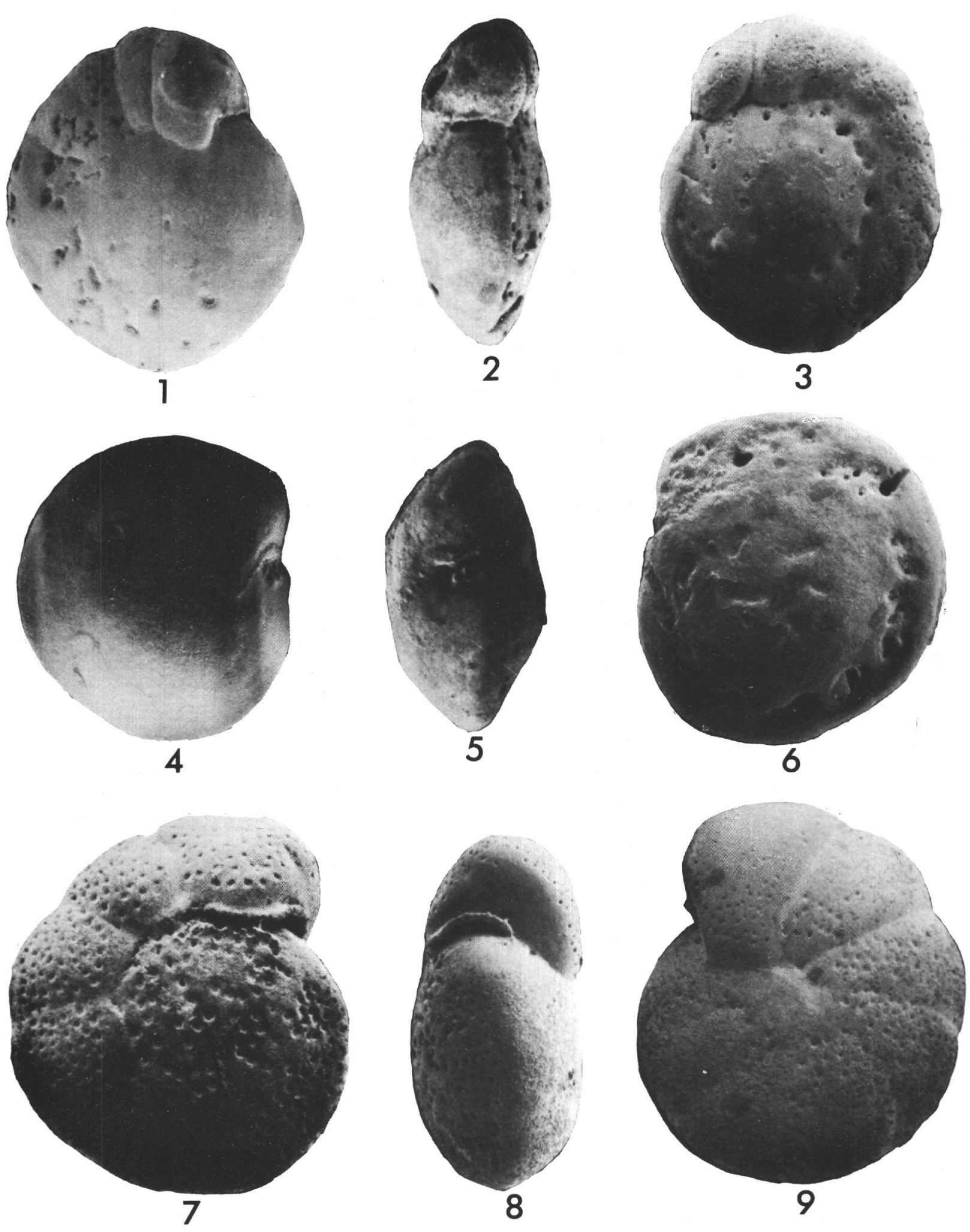
PLATE 17

Figures 1-3 Cibicidoides havanensis (Cushman and Bermudez). Cibicides havanensis Cushman and Bermudez, 1937, Cushman Lab. Foram. Res. Contr., v. 13, p. 28, pl. 3, figs. 1-3. Oligocene, Maximum diameter of specimen, $0.90 \mathrm{~mm}$, Sample 167-8-CC. This large, distinctive species is restricted to the Oligocene in the Pacific, but occurs in the Oligocene and Eocene in the Caribbean region (Cushman and Bermudez, 1937; Beckmann, 1953).

Figures 4-6 Cibicidoides sp. cf. C. subspiratus (Nuttall). Cibicides subspiratus Nuttall, 1930, J.Paleont., v. 4, p. 292, pl. 25 , figs. 9, 10, 14. Eocene. Maximum diameter of specimen, $0.80 \mathrm{~mm}$, Sample 167-33-CC. The species is similar in size and shape to C. subspiratus, but differs in possessing large and distinctive pores. On the spiral side there are pore-like depressions in most of the early chambers, usually one per chamber. In chambers of the final whorl the depressions become interconnected to form a furrow. On the umbilical side the pores are large, and usually two or three form a single depression. The pores form a curved line, radiating from the umbilicus to the periphery of the test. In smaller specimens with a flatter spiral face, the pores are less pronounced and smaller in diamtter, usually not forming furrows.

Figures 7-9 Anomalinoides cicatricosus (Schwager). Anomalina cicatricosus Schwager, 1866, Novara-Exped., Geol. Theil., v. 2, p. 260 , pl. 7, figs. 108, 4. QuaternaryMiddle Miocene, Maximum diameter of specimen, $0.64 \mathrm{~mm}$, Sample 167-3-CC. 
PLATE 17
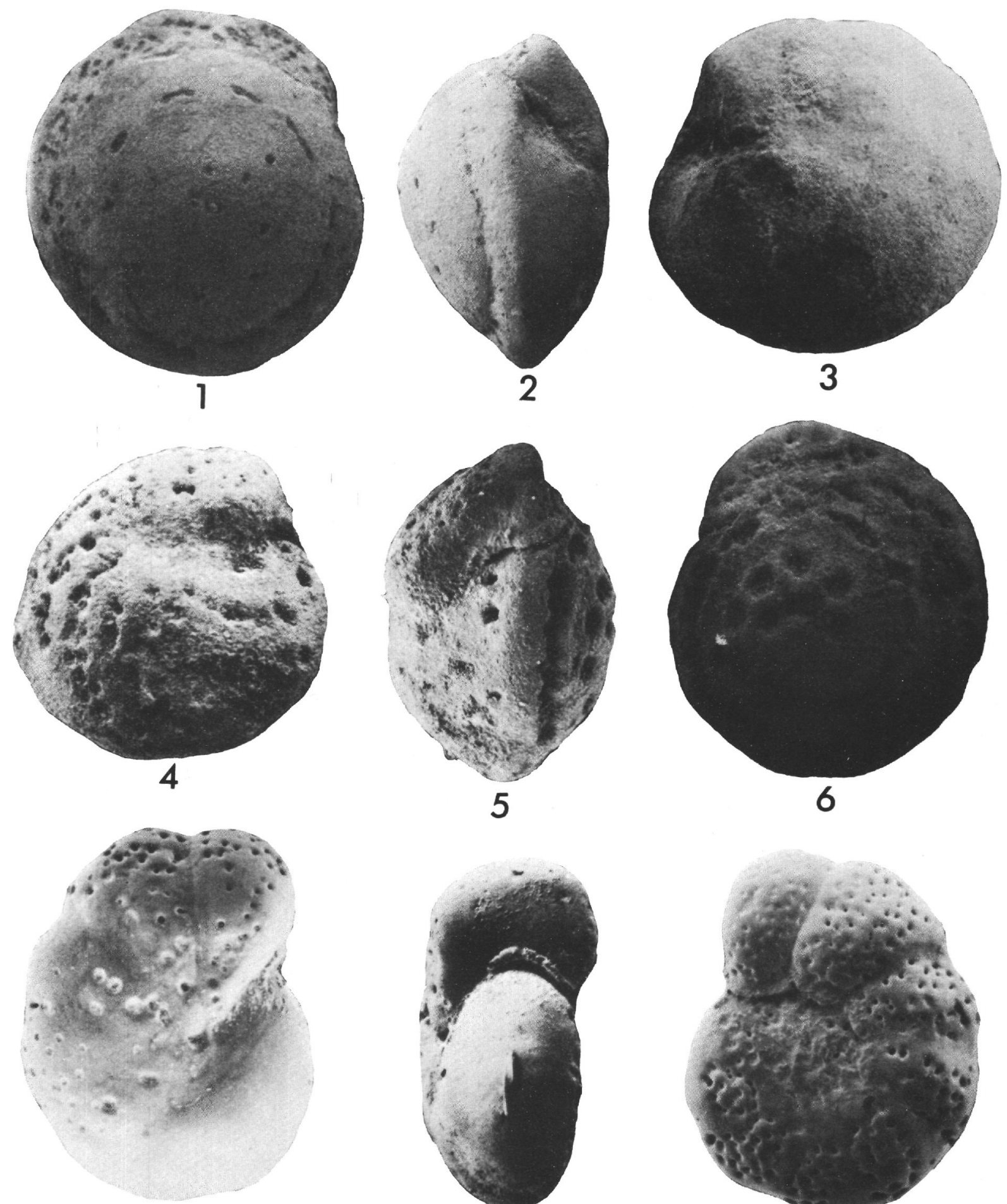

7
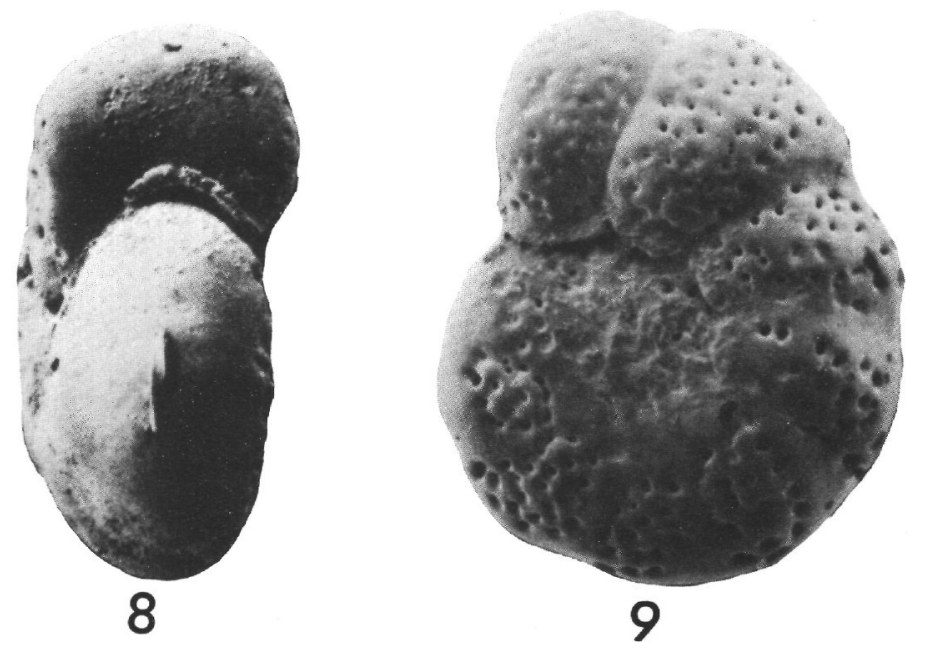


\section{PLATE 18}

Figures 1-3 Gavelinella sp. cf. G. venezuelana (Nuttall). Cibicides venezuelana Nuttall, 1935, J. Paleont., v. 9, p. 131, pl. 15, figs. 25-27. Eocene. Maximum diameter of specimen, $0.50 \mathrm{~mm}$, Sample 167-27-CC. A few specimens occur in Eocene samples at Site 167.

Figures 4-6 Cibicidoides trinitatensis (Nuttall). Truncatulina trinitatensis Nuttall, 1928, Geol. Soc. London Quart. J., v. 84 , p. 97, pl. 7, figs. 3, 5, 6. Middle Miocene-Late Oligocene. Maximum diameter of specimen, $0.88 \mathrm{~mm}$, Sample 167-6-CC. The distinctive elevated, circular ridge or knob of calcite that develops on the inner whorls of the spiral side makes the species easily identified. In juvenile forms the spiral knob is less elevated but still readily observable. Berggren (1972) created the combination Cibicidoides trinitatensis Beckmann (non Nuttall) based on a species identified by Beckmann (1953; pl. 28, figs. 9, 10) as Cibicides cf. trinitatensis (Nuttall). However, it is clear from Nuttall's original description and figures that his species should be placed in the genus Cibicidoides as amended by Loeblich and Tappan (1964). Thus, Cibicidoides trinitatensis (Nuttall, 1928) has priority, and Beckmann's species requires a different name.

Figures 7-9 Cibicidoides wuellerstorfi (Schwager). Anomalina wuellerstorfi Schwager, 1866, Novara-Exped. Geol. Theil., v. 2, p. 258, pl. 7, figs. 105-107. QuaternaryPliocene (?Miocene). Maximum diameter of specimen, 0.70 mm, Sample 167-1-CC. 
PLATE 18
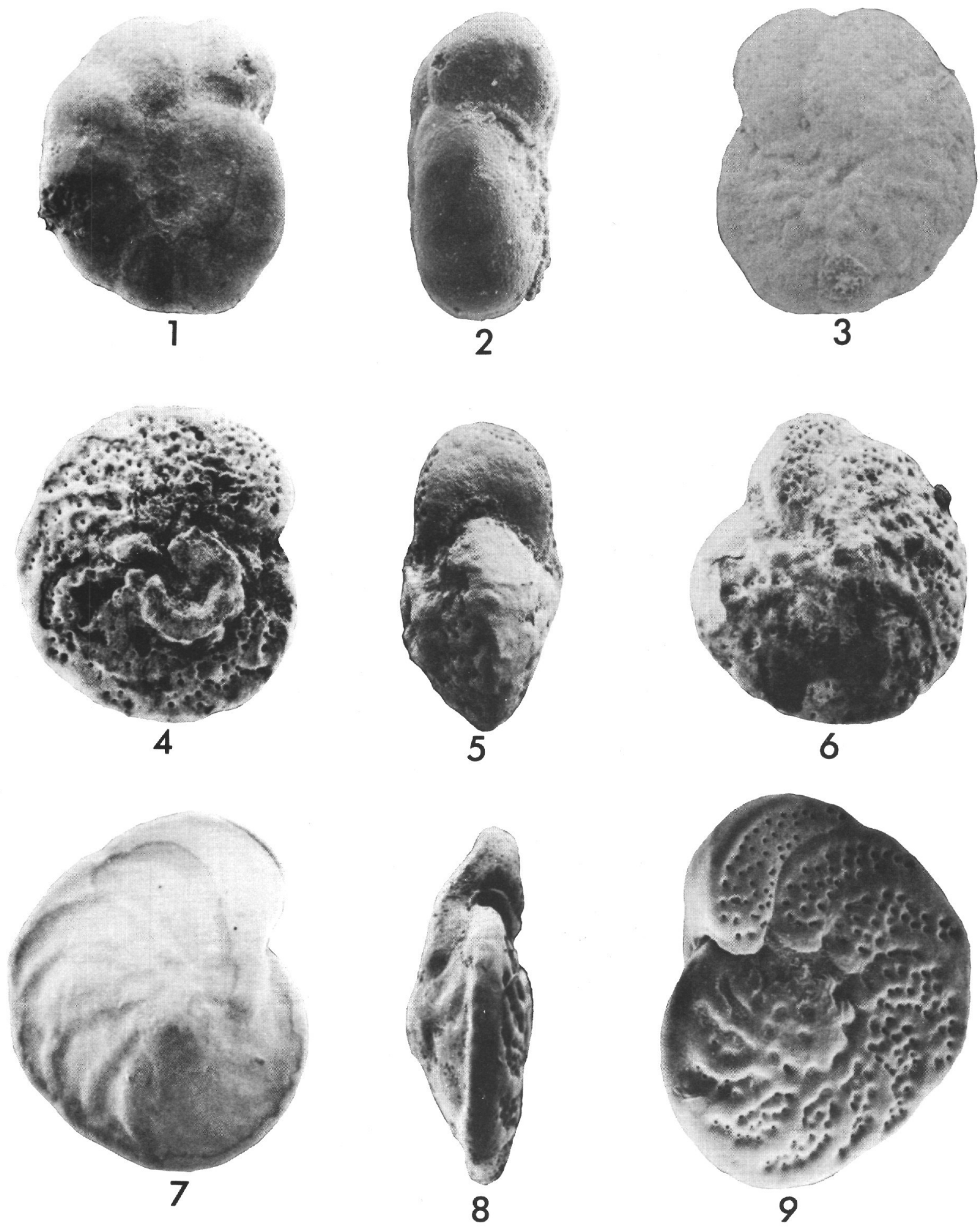


\section{PLATE 19}

Figures 1-3 Cibicidoides jarvisi (Cushman and Stainforth). Gyroidina jarvisi Cushman and Stainforth, 1945, Cushman Lab. Foram. Res. Spec. Publ., v. 14, p. 62, pl. 11, fig. 3. Oligocene, Maximum diameter of specimen, 0.60 $\mathrm{mm}$, Sample 167-10-CC. The species is restricted to the early Oligocene at Site 167 and in the Caribbean region (Beckmann, 1953).

Figures 4, 5 Anomalinoides sp.-1. Late Oligocene, Maximum diameter of species, $0.36 \mathrm{~mm}$, Sample 167-11-6, $70-72 \mathrm{~cm}$. The spiral side of shell is convex and involute, so that only chambers of the last whorl are visible. The umbilical side is flat or slightly concave and less involuted than the spiral side. Small bead-like projections occur on the early chambers of the umbilical side. There are 6-8 chambers in the final whorls, which are greatly inflated on the spiral side of the test. The aperture is a low, interiomarginal arch with a small bordering flap. The aperture remains open on the last 2 or 3 chambers. On the ubmilical side the chambers have numerous small pores, but the spiral side is imperforate and smooth. The species occurs only in the late Oligocene at Site 167.

Figures 6-8 Anomalinoides alazanensis (Nuttall). Anomalina alazanensis Nuttall, 1932, J. Paleont., v. 6, p. 32, pl. 8, figs. 5-7. Oligocene-Eocene, Maximum diameter of specimen, $0.48 \mathrm{~mm}$, Sample 167-6, 70-72 $\mathrm{cm}$. 


\section{PLATE 19}
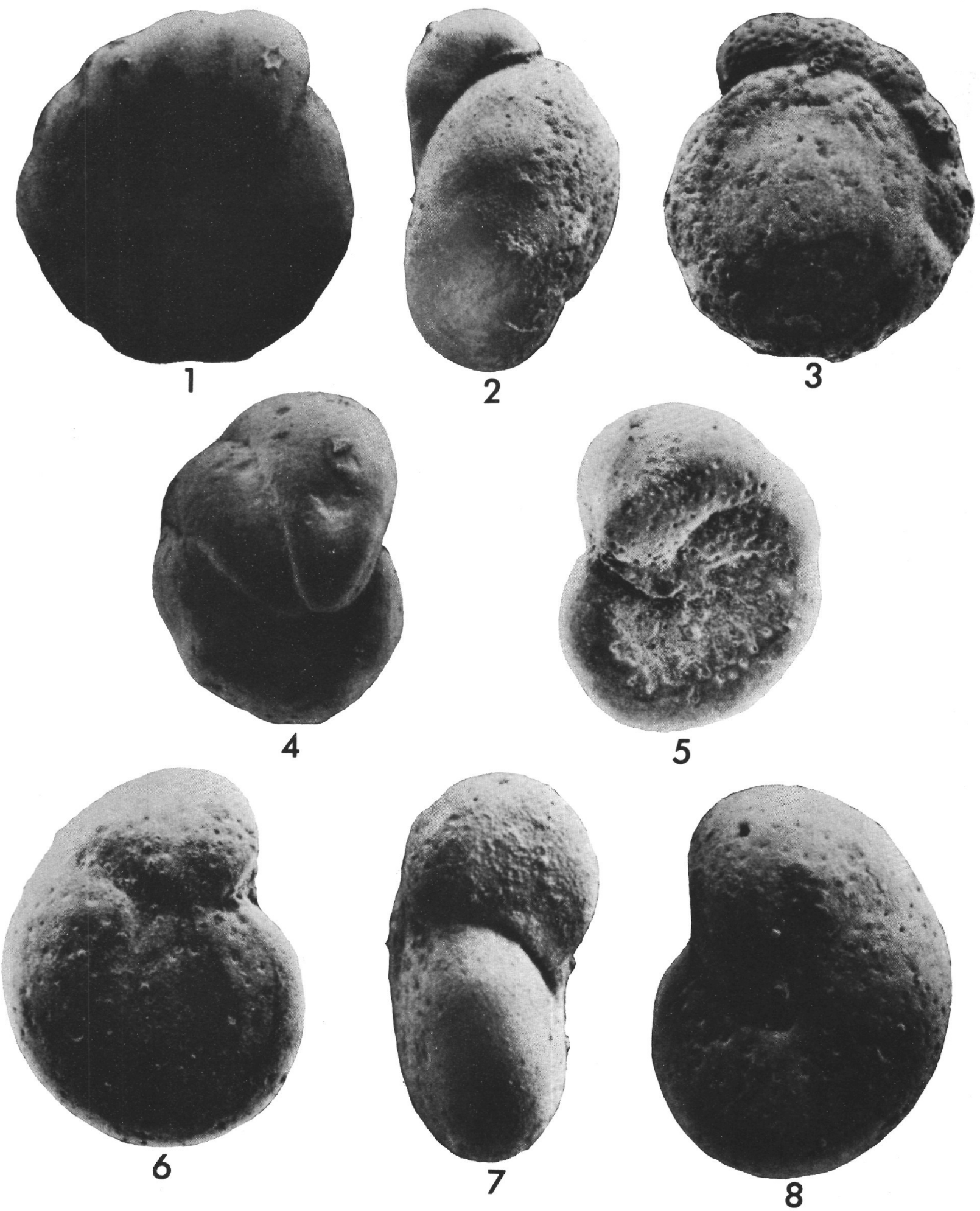
PLATE 20

Figures 1-3, 7-9 Cibicidoides pseudoungerianus (Cushman). Truncatulina pseudoungeriana Cushman, 1922, U. S. Geol. Surv. Prof. Paper 129, p. 97, 136, pl. 20, fig. 9. Oligocene-Eocene. A variety of species have been referred to this species, as indicated by the different forms illustrated by Cushman and other authors. The species distinguished here agrees well with the description of Galloway and Heminway (1941) and the figures of Beckmann (1953). The species defined in this sense ranges from the mid Eocene to Oligocene or early Miocene in the Caribbean and Pacific.

1-3. Maximum diameter of specimen, $0.62 \mathrm{~mm}$, Sample 171-8-CC.

7-9. Maximum diameter of specimen, $0.50 \mathrm{~mm}$, Sample 167-10-CC.

Figures 4-6 Cibicidoides coryelli (Bermudez) (see pl. 25, figs. 5, 6, 9, 10). Cibicides coryelli Bermudez, 1949, Cushman Lab. Foram. Res. Spec. Publ., v. 25, p. 296, pl. 25, figs. 7-9. Miocene-Eocene, Maximum diameter of specimen, $0.60 \mathrm{~mm}$, Sample 171-4-CC. The species is restricted to Site 171. 

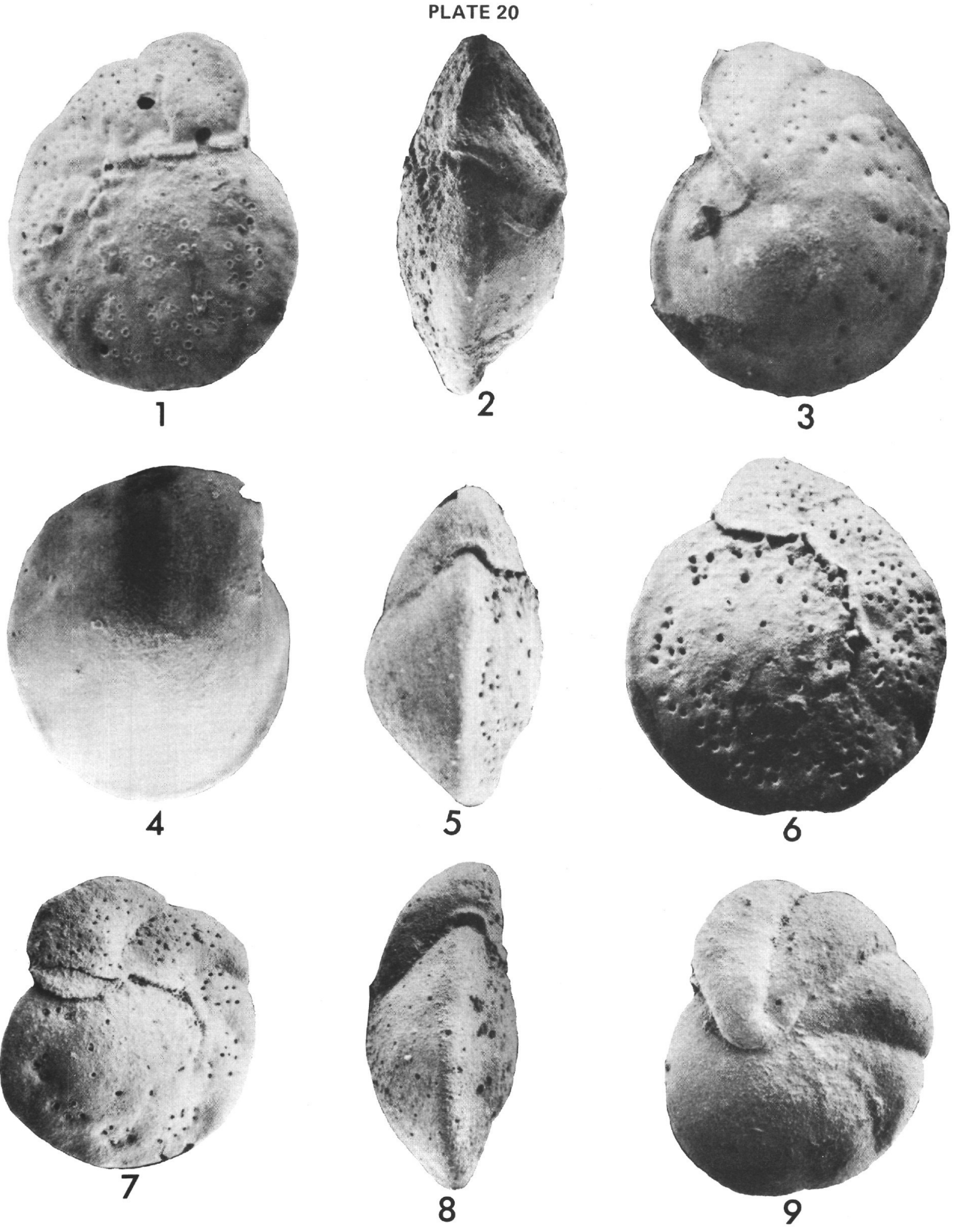


\section{PLATE 21}

Figures 1-3 Alabamina dissonata (Cushman and Renz) (see pl. 24, figs. 3, 4). Pulvinulinella atlantisae Cushman var. dissonata Cushman and Renz, 1948, Cushman Lab. Foram. Res. Spec. Publ., v. 24, p. 35, pl. 7, figs. 11, 12. Eocene. Maximum diameter of specimen, 0.44 $\mathrm{mm}$, Sample 167-27, CC. This distinctive species is limited to the Eocene in the Caribbean region and in the east Pacific (Beckmann, 1971).

Figures 4-6 Nuttallides treumpyi (Nuttall) (see pl. 24, figs. 1, 2). Eponides treumpyi Nuttall, 1930, J. Paleont., v. 4, p. 271, pl. 24, figs. 9, 13, 14. Eocene. Maximum diameter of specimen, $0.44 \mathrm{~mm}$, Sample 167-33-CC. The shell is inequally biconvex, with the umbilical side being much more inflated than the spiral side. A large umbilical plug is formed of clear shell material. Eight to ten chambers occur in the last whorl and are bordered by a narrow keel. The sutures on the spiral side are straight, and in later chambers are nearly tangential to the axis of coiling. It is a marker for the Eocene.

Figures 7-9 Caribeanella sp. Oligocene, Maximum diameter of specimen, $0.60 \mathrm{~mm}$, Sample 171-5-CC. Rare specimens of this distinctive species occur in Oligocene sediments at both sites. The coarse nodes on the center of the flattened spiral side resembles $C$. trinitatensis. However, it may be distinguished by its plano-convex test and the development of supplementary apertures on the spiral side at the backward margin of the chamber. The spiral side is more coarsely perforated than the umbilical side. 


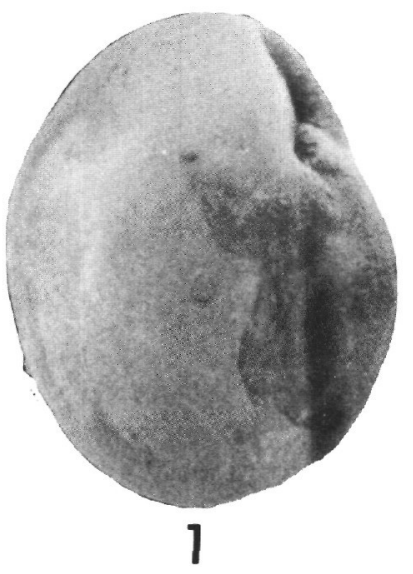

\section{PLATE 21}
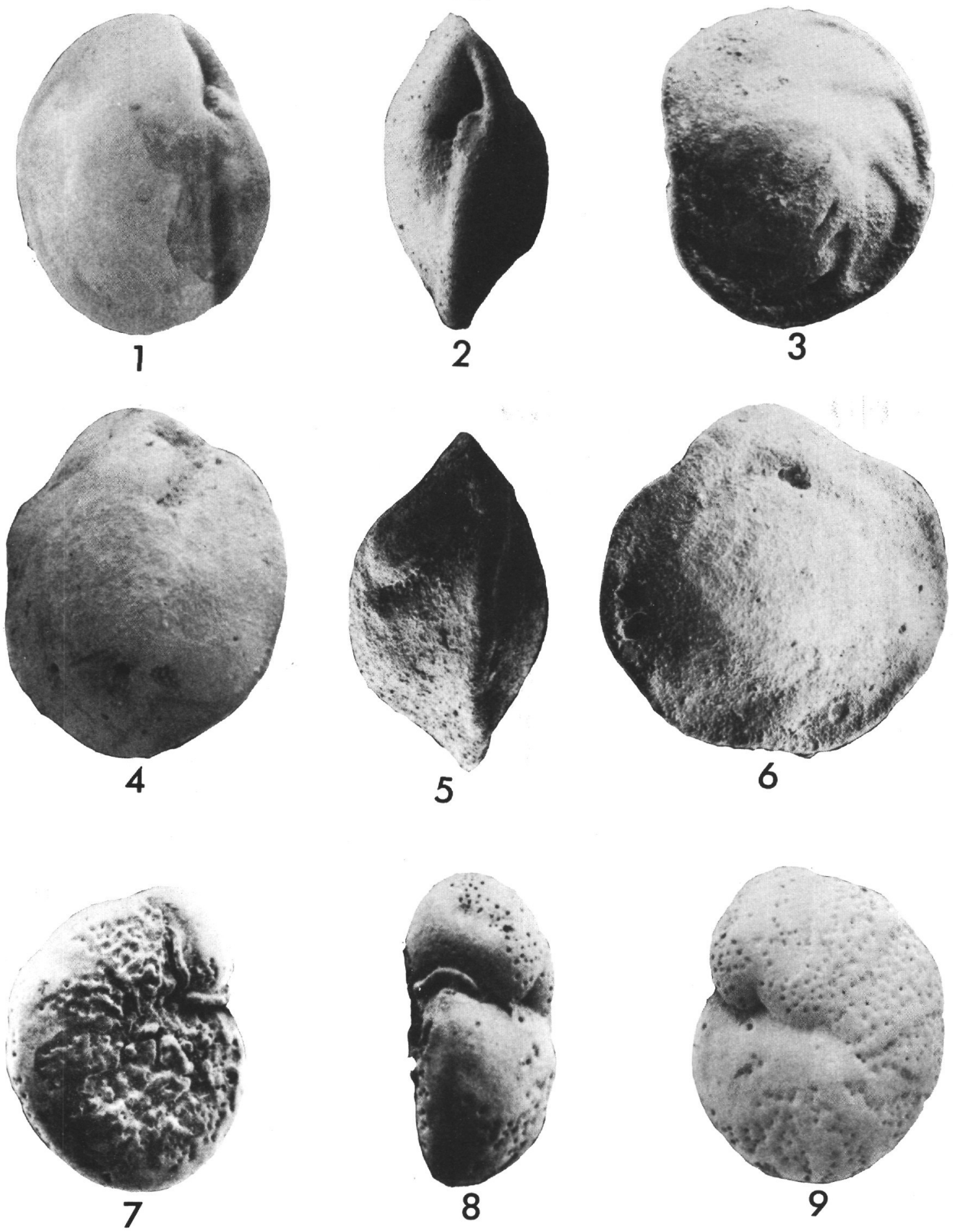
PLATE 22

Figures 1-3 Gyroidina girardana (Reuss). Rotalina girardana Reuss, 1851, A. Deutsch. Geol. Gesell., v. 3, p. 73, pl. 5, fig. 34. Early Miocene-Eocene. Maximum diameter of specimen, $0.56 \mathrm{~mm}$, Sample 171-8-CC. This large species may be separated from the other gyroidinids in the area by the sharp edge of the spiral face of the last two or three chambers and the keel-like edge of the margin of the last chamber. The spiral face is flat or slightly depressed.

Figures 4-6 Gyroidina complanata Cushman and Stainforth, 1945, Cushman Lab. Foram. Res. Spec. Publ., v. 14, p. 61, pl. 11, fig. 2. Pliocene-Oligocene. Maximum diameter of specimen, $0.56 \mathrm{~mm}$, Sample 171-4-CC.

Figures 7-9 Gryoidina perampla Cushman and Stainforth. Gryoidina girardana (Reuss) var perampla Cushman and Stainforth, 1945, Cushman Lab. Foram. Res. Spec. Publ., v. 14, p. 61, pl. 10, fig. 19. Early Miocene-Eocene. Maximum diameter of specimen, $0.64 \mathrm{~mm}$, Sample 171-5-CC. 


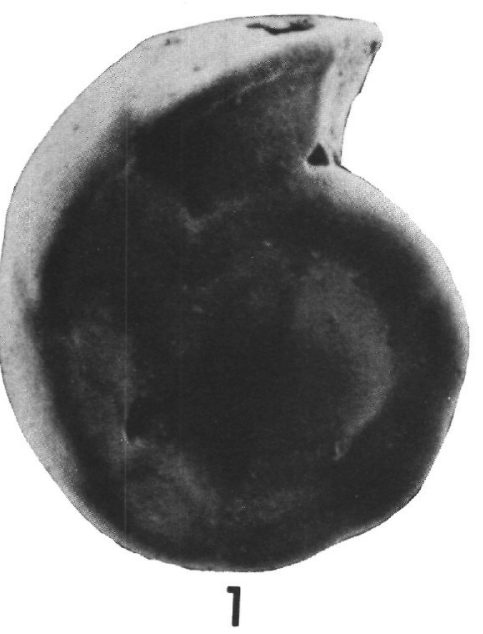

PLATE 22
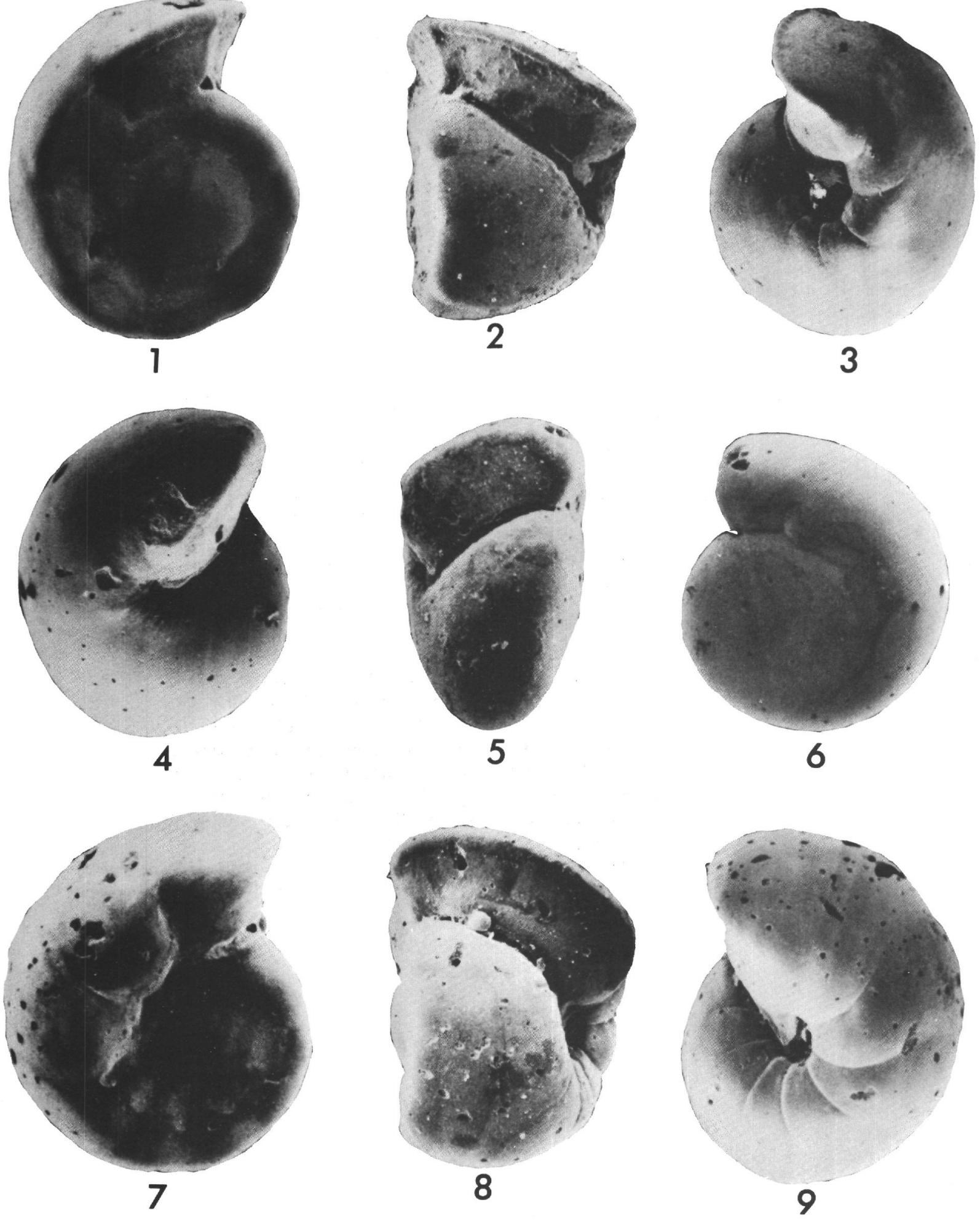
PLATE 23

Figures 1-5 Anomalinoides pompilioides (Galloway and Heminway). Anomalina pompilioides Galloway and Heminway, 1941, N. Y. Acad. Sci., Sci. Survey Puerto Rico, v. 3 , p. 389 , pl. 22 , fig. 3 . Oligocene-Eocene. The shell is more involute on the umbilicate side than the spiral side and there are 6-7 chambers per whorl. Both sides of the shell are covered with large pores.

1-3. Maximum diameter of specimen, $0.72 \mathrm{~mm}$, Sample 167-33, CC.

4, 5. Maximum diameter of specimen $0.68 \mathrm{~mm}$, Sample 171-5, CC.

Figures 6-8 Anomalinoides aragonensis (Nuttall) Anomalina dorri Cole var aragonensis Nuttall, 1930, J. Paleont., v. 4, p. 291, pl. 24, fig. 18; pl. 25, fig. 1. Eocene. Maximum diameter of specimen, $0.92 \mathrm{~mm}$, Sample $171-8-5,70-72 \mathrm{~cm}$. This species was originally described as a variety of $A$. dorri Cole. However, it differs by the greater number of chambers in the final whorl, less involute coil, deep and narrow umbilical depression, and larger and more numerous pores. The species seems to be restricted to the Eocene. 

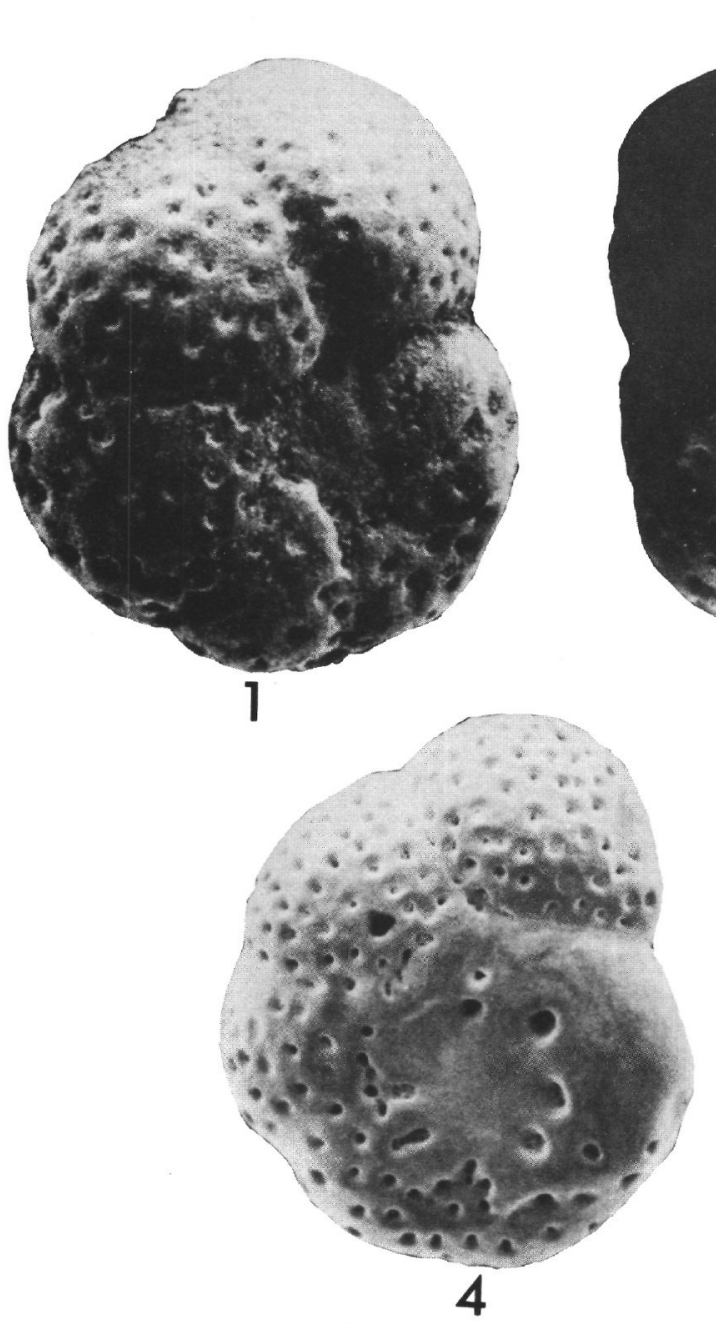

PLATE 23
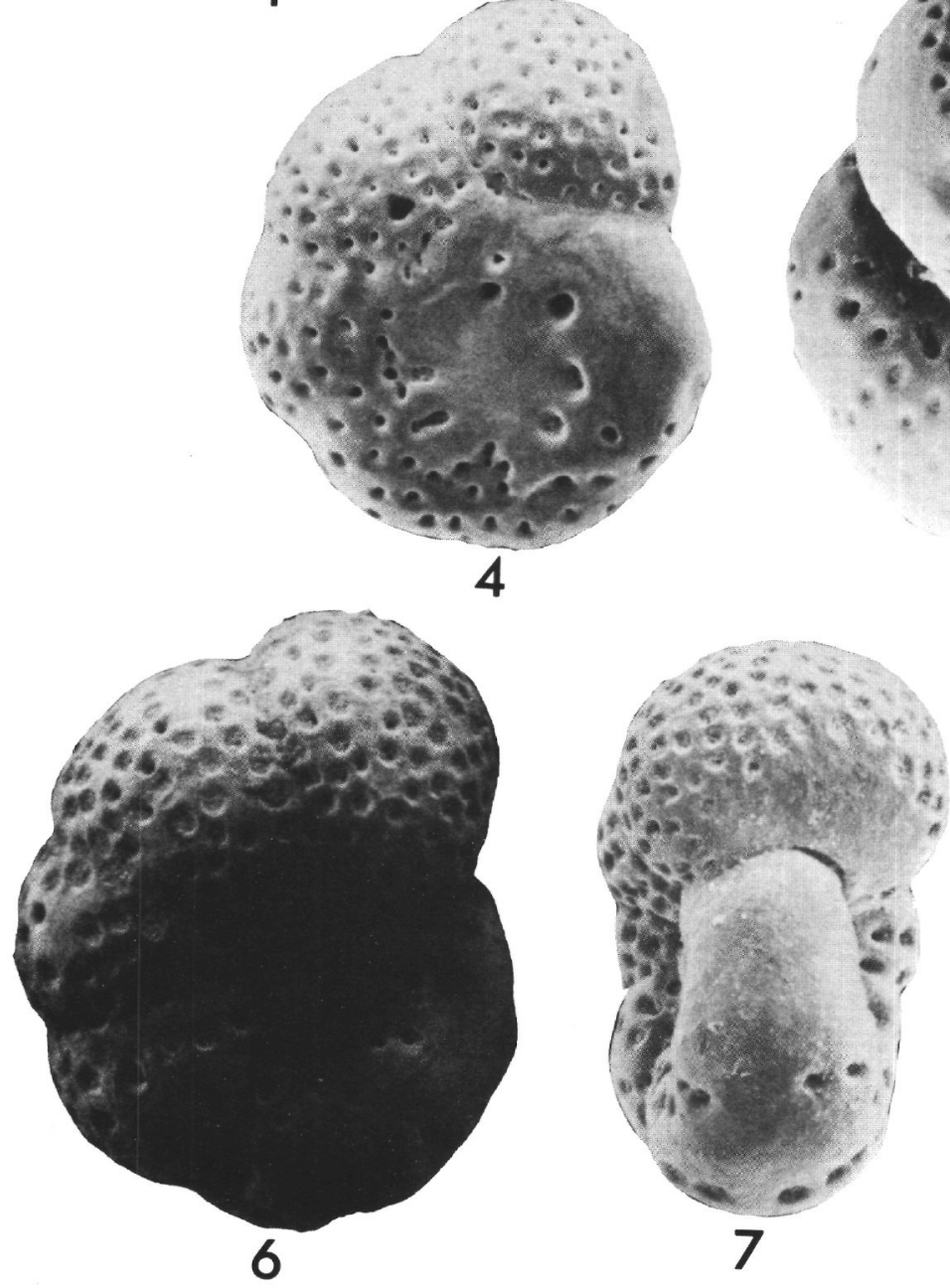

5

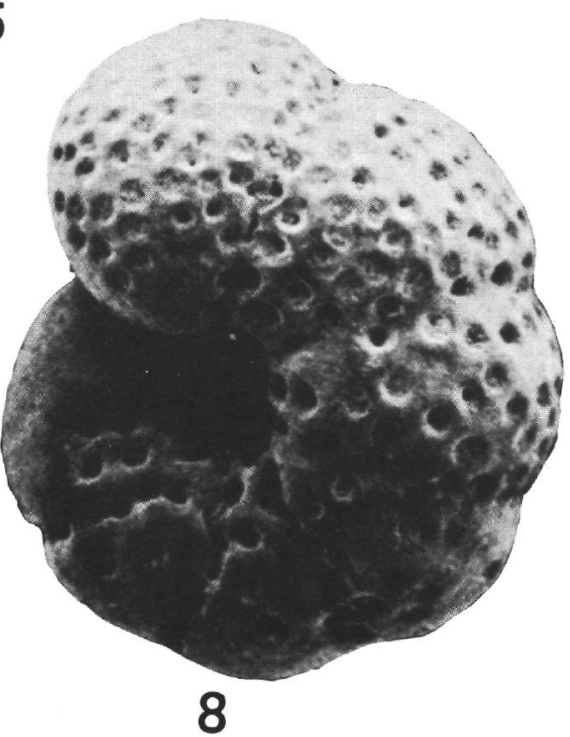




\section{PLATE 24}

Figures 1,2 Nuttallides truempyi (Nuttall) (see pl. 21, figs. 4-6). Maximum diameter of specimen, $0.58 \mathrm{~mm}$, Sample 167-27-CC.

Figures 3,4 Alabamina disonata (Cushman and Renz) (see pl. 21, figs. 1, 2). Maximum diameter of specimen, $0.48 \mathrm{~mm}$, Sample 167-29-CC.

Figures 5,6 Gyroidina zealandica Finlay (see pl. 12, figs. 4-9). Maximum diameter of specimen, $0.82 \mathrm{~mm}$, Sample 167-4-CC.

Figures 7, 8 Cibicidoides jarvisi (Cushman and Stainforth) (see pl. 19, figs. 1-3), Maximum diameter of specimen, 0.62 $\mathrm{mm}$, Sample 167-10-CC.

Figures 9-10 Oridorsalis umboynatus (Reuss) (see pl. 13, figs. 1-3). Maximum diameter of specimen, $0.78 \mathrm{~mm}$, Sample 167-10-CC.

Figures 11,12 Oridorsalis umbonatus (Reuss) (see pl. 13, figs. 4-6). Maximum diameter of specimen, $0.62 \mathrm{~mm}$, Sample 167-10-CC.

Figures 13,14 Cibicidoides perlucidus (Nuttall) (see pl. 15, figs. 7-9). Maximum diameter of specimen, $1.22 \mathrm{~mm}$, Sample 167-21-4, 70-72 cm.

Figures 15, 16 Anomalinoides sp. (see pl. 19, figs. 4, 5). Maximum diameter of specimen, 0.34 mm, Sample 167-11-6 $70-72 \mathrm{~cm}$.

Figures 19,20 Cibicidoides havanensis (Cushman and Bermuidez) (see pl. 17, figs. 1-3). Maximum diameter of specimen, $0.56 \mathrm{~mm}$, Sample SOTOW 11-73P.

Figures 17, 18 Cibicidoides perlucidus (Nuttall). Maximum diameter of specimen, $0.74 \mathrm{~mm}$, Sample 171-8-3, 70-72 cm. 

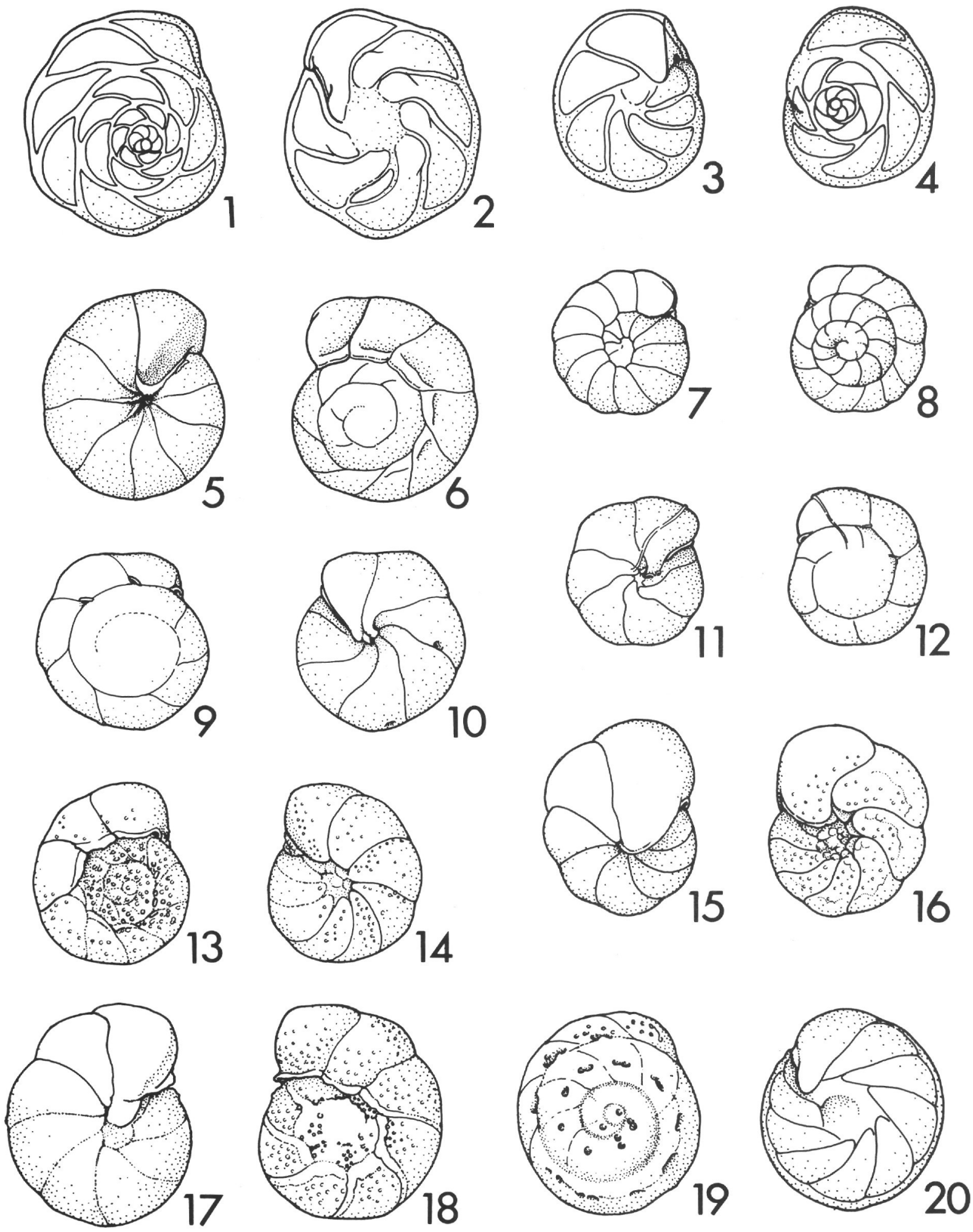


\section{PLATE 25}

Figures 1,2 Anomalinoides alazanensis (Nuttall) (see pl. 19, figs. 6-8). Maximum diameter of specimen, $0.44 \mathrm{~mm}$, Sample 167-11-5, 70-72 cm.

Figures 3, $4 \quad$ Cibicidoides haitensis (Coryell and Rivero) (see pl. 16 , figs. 1-6). Maximum diameter of specimen, 0.66 $\mathrm{mm}$, Sample 171-4-CC.

Figures 5,6 Cibicidoides coryelli (Bermudez) (see pl. 20, figs. 4-6). Maximum diameter of specimen, $0.52 \mathrm{~mm}$, Sample 171-4-CC.

Figures 7,8 Cibicidoides pseudoungerianus (Cushman) (see pl. 20, figs. 1-3, 7-9). Maximum diameter of specimen, 0.48 mm, Sample 171-8-CC.

Figures 9, 10 Cibicidiodes coryelli (Bermudez) (see pl. 20, figs. 4-6). Maximum diameter of specimen, $0.60 \mathrm{~mm}$, Sample 171-8-CC.

Figures 11,12 Cibicidoides trinitatensis (Nuttall) (see pl. 18, figs. 4-6). Maximum diameter of specimen, $0.68 \mathrm{~mm}$, Sample 167-6-CC.

Figures 13, 14 Cibicidoides grimsdalei (Nuttall) (see pl. 15, figs. 1-6). Maximum diameter of specimen, $0.84 \mathrm{~mm}$, Sample 167-10-CC.

Figures 15, 16 Cibicidoides wuellerstorfi (Schwager) (see pl. 18, figs. 7-9). Maximum diameter of specimen, $0.72 \mathrm{~mm}$, Sample 167-3-3, 70-72 cm.

Figures 17, 18 Osangularia mexicana (Cole) (see pl. 11, figs. 4-6). Maximum diameter of specimen, $0.88 \mathrm{~mm}$, Sample 167-27-CC.

Figures 19, 20 Osangularia interrupta (Cushman) (see pl. 11, figs. 1-3). Maximum diameter of specimen, $0.52 \mathrm{~mm}$, Sample 171-5-CC. 

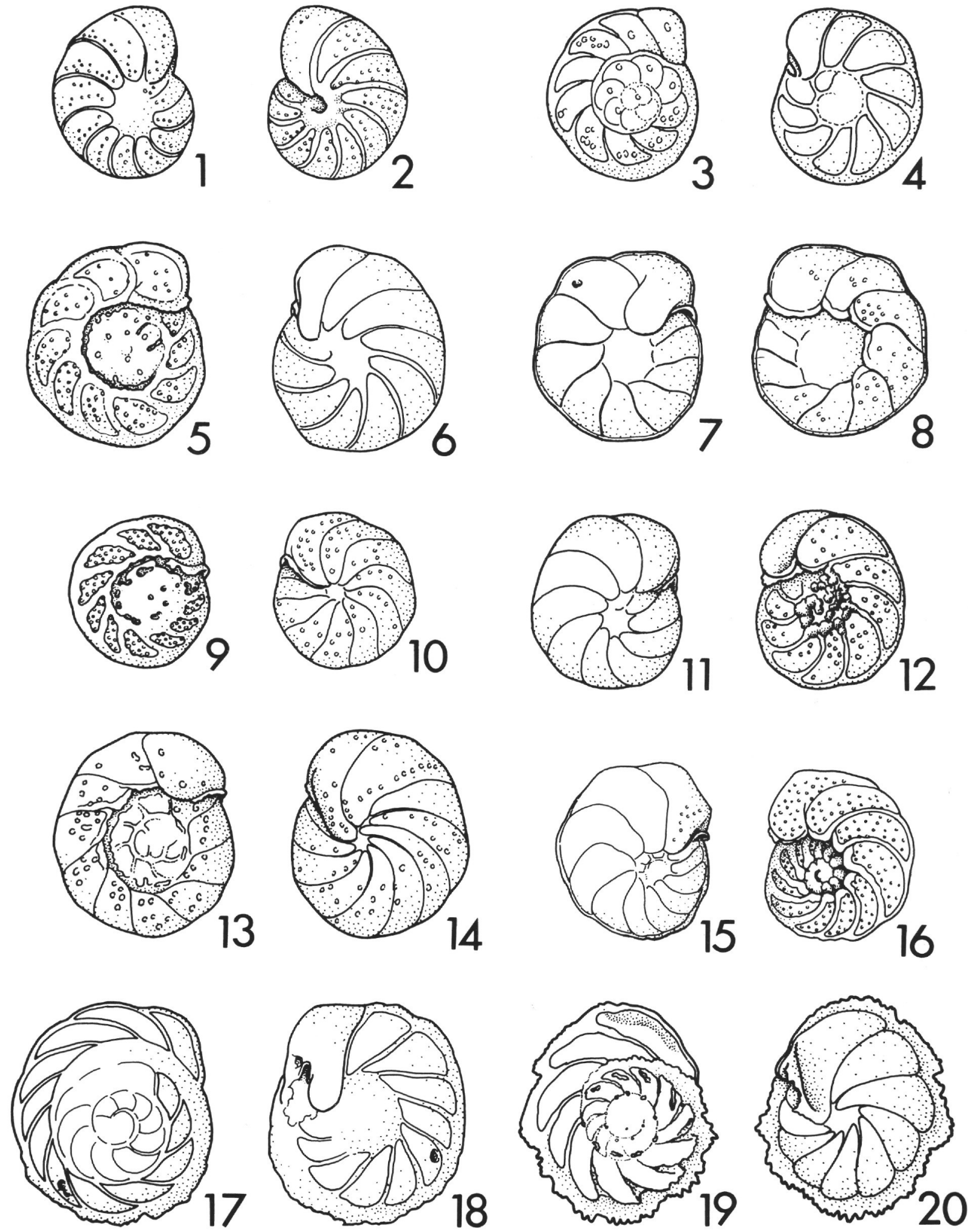